\title{
Avaliação microscópica e bioquímica comparativa da membrana de osso cortical bovino desmineralizado, tratada ou não com tetraciclina, implantada em subcutâneo de ratos.
}

RODRIGO CARDOSO DE OLIVEIRA

Dissertação apresentada à Faculdade de Odontologia de Bauru, Universidade de São Paulo, para obtenção do grau de Mestre em Odontologia - área Endodontia

(Edição Revisada)

BAURU 


\section{Avaliação microscópica e bioquímica comparativa da membrana de osso cortical bovino desmineralizado, tratada ou não com tetraciclina, implantada em subcutâneo de ratos.}

RODRIGO CARDOSO DE OLIVEIRA

Dissertação apresentada à Faculdade de Odontologia de Bauru, Universidade de São Paulo, para obtenção do grau de Mestre em Odontologia - área Endodontia

Orientador: Prof. Dr. José Mauro Granjeiro

BAURU

2003 
Oliveira, Rodrigo Cardoso

O14a Avaliação microscópica e bioquímica comparativa da membrana de osso cortical bovino desmineralizado, tratado ou não com tetraciclina, implantado em subcutâneo de ratos/Rodrigo Cardoso de Oliveira. -- Bauru, 2003.

103 p. : il. ; $30 \mathrm{~cm}$.

Dissertação. (Mestrado) - Faculdade de Odontologia de Bauru. Universidade de São Paulo.

Orientador: Prof Dr José Mauro Granjeiro

Autorizo, exclusivamente para fins acadêmicos e científicos, a reprodução total ou parcial desta dissertação, por processos fotocopiadores e/ou meio eletrônico.

Assinatura do autor :

Data: 
RODRIGO CARDOSO DE OLIVEIRA

Nascimento

Filiação

1996-1999

2001-2003

Associações
07/03/1977

Assis - SP

Lourival Cardoso de Oliveira

Maria Dolores Dionízio de Oliveira

Curso de Graduação em Odontologia na Faculdade de Odontologia de Bauru, Universidade de São Paulo

Curso de Pós-Graduação em Odontologia, área de Endodontia, nível de Mestrado, na Faculdade de Odontologia de Bauru - USP

CRO - Conselho Regional de Odontologia - SP 


\section{Agradecimentos}

Agradeço primeiramente a Deus por me cercar de muitos amigos e pela melhor família que alguém poderia ter.

Agradeço aos meus pais, Lourival Cardoso de Oliveira e Maria Dolores Dionízio de Oliveira, por toda sua dedicação a mim e meu irmão Rogério Cardoso de Oliveira. Por todo sofrimento que eu os fiz passar. Tenho certeza que sem eles nada do que fiz de bom ate hoje seria possível.

Ao meu orientador e amigo Prof. José Mauro Granjeiro pelos seus ensinamentos e pelo seu apoio e confiança na minha pessoa. A minha eterna admiração, respeito e carinho.

Ao Prof. Rumio Taga que sempre esteve auxiliando com seu imenso conhecimento.

A Prof Marília Afonso Rabelo Buzalaf pela ajuda e apoio sempre certos, sendo um dos melhores exemplos de competência e determinação para mim.

Ao Prof. Eulázio Mikio Taga que para mim, como para muitos, serve de parâmetro como pesquisador pelo seu vasto conhecimento.

Aos professores do Departamento de Endodontia: Clovis Bramante pela sua dedicação conosco, alunos da pós-graduação; Norberti Bernardineli pelo seu incentivo e prestação; Roberto Brandão Garcia pelo exemplo de caráter como profissional e pessoa; Ivaldo Gomes de Moraes pela atenção e pelo carinho de pai.

Aos funcionários da Bioquímica Thelma, Ovídio, Pamela e Gilmar que muito fizeram para que meu trabalho desse certo e pela amizade construída nesses anos.

Aos funcionários da Endodontia Edimauro, Dona Neide, Suely e Patrícia pela ajuda e apoio.

Aos funcionários do Biotério Luiz, Erasmo e Richard sempre muito tolerantes com minha pesquisa.

A Vera Lúcia, secretária do departamento de Ciências Biológicas pela ajuda em diversos momentos. 
A Daniele e Tania da Histologia pela imensa colaboração, sem a qual o meu trabalho não teria terminado.

A Elide pelo seu carinho e auxilio na hora certa.

Aos meus amigos da Bioquímica Ana Claudia Demarchi, Ana Paula Bassetto, Esther Takamori, Flavia Levy, Willian Zambuzzi, Katiucia Paiva, Vanessa Cardoso, Juliano Pelissan, Thais Accorsi, Mauro Corotti, Kellen Gasque, Tatiana Furlani, Tatiane, Cristina Miguel Sicca, Renato Sartori, Danilo Januário, Bruno Subitoni, Jefferson Sanada, José Gustavo, Fabio Gelonese, Alysson Côrrea, Maria Heloisa, Rejane Fukushima, Juliane Carvalho, Jose Victor, Eduardo, Irene.

Aos amigos de mestrado: Everdan Carneiro, Leandro Bassili, Fernanda de Moraes, Giovana Canova, Jazzmina Torres, Renato Menezes, Maristela Amorim, Sergio Brunini.

Aos colegas dos outros mestrados: Heitor, Sheila, Marcelo, Alexandre e Glória (Odontopediatria); Marcio e Carla (colegas de Graduação e da Periodontia); Josiane, Flavio e Cláudio (Estomatologia), Jefferson (prótese), Diego, Leonardo e Nathalia (Dentistica), Renato, Anderson (Materiais Dentários).

A Nicole Kawauchi minha amiga, quase irmã, que me ajudou nos momentos mais difíceis de minha caminhada.

Aos meus amigos quase irmãos Rodrigo Camargo, Fabiano Sinzato, Ricardo Schiavuzzo, Guilherme Garcia, Flavio Nakatani, Felipe Pereira.

Aos meus amigos de Republica: Fernando Torres, André Sakima, Vladimir Salazar, Victor Hugo, Julio Vernes e Marcelo Zanda.

À Faculdade de Odontologia de Bauru, em nome da sua Diretora Professora Doutora Maria Fidela de Lima Navarro.

À comissão de pós-graduação, por meio de seu presidente o Professor Doutor José Carlos Pereira.

Ao CNPq, pelos recursos financeiros. 


\section{SUMÁRIO}

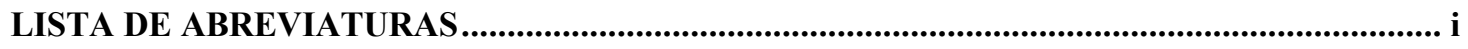

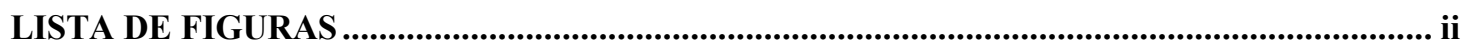

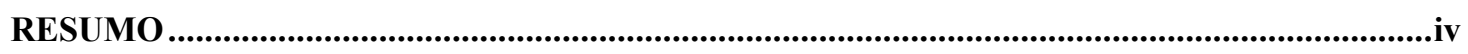

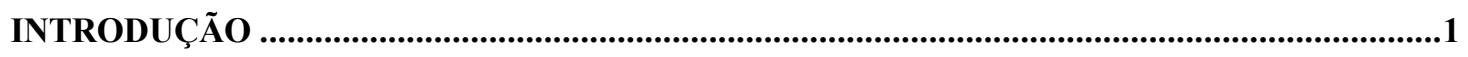

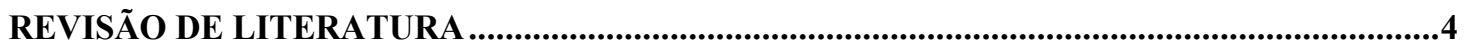

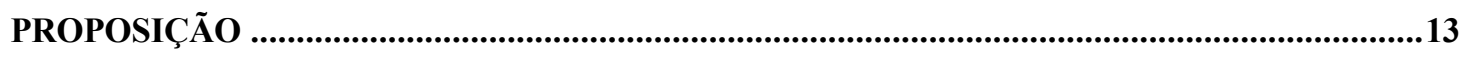

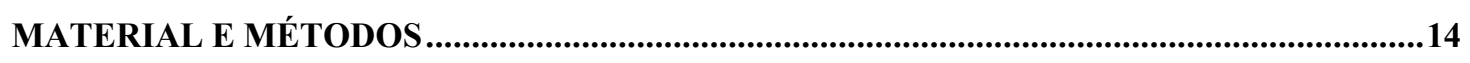

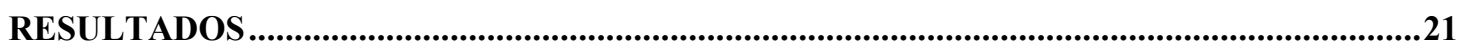

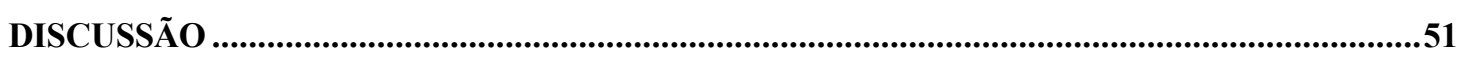

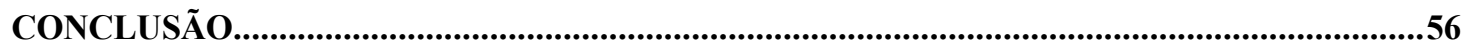

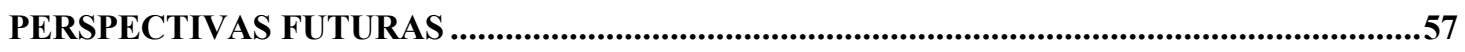

REFERENCIAS BIBLIOGRAFICAS ….................................................................................58

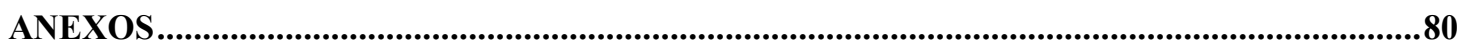

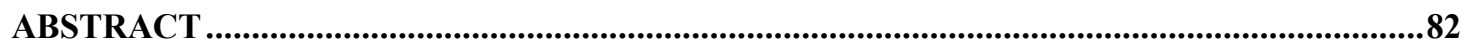


LISTA DE ABREVIATURAS:

$\beta$-hexosaminidase - $\beta$-HEXO

Ácido Etilenodiaminotetracético - EDTA

Arilsulfatase - ARIL

Arilsulfatase $A$ - ASA

Arilsulfatase $B$ - ASB

Atividade específica - AE

Demineralized freeze-dried bone allografts - DFDBA

Esteróide sulfatase - STS

Food and Drug Administration - FDA

Fosfatase ácida de baixa massa molecular relativa - PTP`s

Fosfatase ácida lisossomal - FAL

Fosfatase ácida tartarato resistente - FATR

Fosfatase ácida total - FAT

Fosfatase alcalina - Falc

Fosfato de $p$ - Nitrofenil - $p$-NPP

Hidroximetilaminometano - TRIS

Massa Molecular Relativa - Mr

Metaloproteinases de matriz - MMPs

P-hidroximercuribenzoato - $\mathrm{pHMB}$

Platelet-derived growth factor-PDGF

Polimorfonucleados - PMNs

Politetrafluoretileno expandido - PTFEe

Proteína morfogenética do osso ou bone morphogenetic proteins - BMPs

Regeneração óssea guiada - ROG

Regeneração tecidual guiada - RTG

Tetraciclina - TETRA

Transforming growth factor beta - TGF- $\beta$

Unidade Enzimática - UE 


\section{LISTA DE FIGURAS}

Figura 1. A) Embalagem comercial da Gen-derm $\left.{ }^{\circledR} ; B\right)$ Aspecto macroscópico da Gen-derm ${ }^{\circledR}$ à esquerda e Gen-derm ${ }^{\circledR}$ tratada com tetraciclina à direita. 14

Figura 2. Implantação da membrana no tecido subcutâneo. 15

Figura 3. Protocolo para extração e dosagem de atividade das fosfatases ácidas, arilsulfatase, ßhexosaminidase e alcalina.

Figura 4. Fotomicrografia do periodo de 1 e 3 dias. Em A (1 dia) a membrana (M) apresentava-se aparentemente intacta, notamos ainda a presença de vasos nos tecidos adjacentes $(\rightarrow)$. Em B (3 dias) é possível distinguir pequenos vasos $(\rightarrow)$ bem próximos à margem da membrana (M). Aumento: A 10X; B 10X. Coloração hematoxilina-eosina.

Figura 5. Fotomicrografia do período de 7 dias. Neste periodo a membrana (M, em A) apresenta-se aparentemente intacta e envolta por células mononucleadas (*). Em maior aumento (B) é possivel distinguir pequenos vasos $(\rightarrow)$ bem próximos à margem da membrana (M). Aumento: A 10X; B 40X. Coloração hematoxilina-eosina.

Figura 6. Fotomicrografia do periodo de 15 dias. Neste período a membrana (M, em A) apresenta-se com sinais de invasão e degradação ( ), cercada de células mononucleadas (*) oriundas dos tecidos adjacentes, presença de inúmeros vasos congestos $(\rightarrow)$. Em maior aumento $(B)$ é possivel distinguir pequenos vasos $(\rightarrow)$ bem próximos à margem da membrana (M). Aumento: A 10X; B 40X. Coloração hematoxilina-eosina.

Figura 7. Fotomicrografia do periodo de 30 dias. Neste periodo notamos os fragmentos da membrana (M, em A) sinais de degradação ( ), presença de vasos $(\rightarrow)$. Em maior aumento (B) é possivel observar a membrana (M) sendo invadida por células mononucleadas (*). Aumento: A 10X; B 40X. Coloração hematoxilina-eosina.

Figura 8. Fotomicrografia do periodo de 60 dias. Neste periodo não encontramos os fragmentos, ou sinais da membrana (em $A$ ) ou (B, maior aumento). Havia apenas tecidos normais sem sinais da membrana. Aumento: A 10X; B 40X. Coloração hematoxilina-eosina.

Figura 9. Fotomicrografia do periodo de 1 e 3 dias. Em A (1 dia) a membrana (M) apresentava-se aparentemente intacta, notamos ainda a presença de vasos nos tecidos adjacentes $(\rightarrow)$. Em B (3 dias) é possível distinguir pequenos vasos $(\rightarrow)$ bem próximos à margem da membrana (M). Aumento: A 10X; B 10X. Coloração hematoxilina-eosina.

Figura 10. Fotomicrografia do periodo de 7 dias. Neste periodo a membrana ( $M$ em A) apresentava-se aparentemente intacta, notamos ainda a presença de vasos nos tecidos adjacentes $(\rightarrow)$. Em maior aumento $(B) e ́$ possivel distinguir pequenos vasos $(\rightarrow)$ bem próximos à margem da membrana (M). Aumento: A 10X; B 40X. Coloração hematoxilina-eosina. 32

Figura 11. Fotomicrografia do periodo de 15 dias. Neste periodo a membrana (M em A) apresentava-se com sinais de invasão e degradação ( ), presença de inúmeros vasos congestos $(\rightarrow)$. Em maior aumento (B) é possivel distinguir pequenos vasos $(\rightarrow)$ bem próximos à margem da membrana (M). Aumento: A 10X; B 40X. 
Figura 12. Fotomicrografia do periodo de 60 e 30 dias. Neste periodo (60 dias) fragmentos da membrana (M em A)podiam ser vistos, além de sinais de degradação da membrana ( ) e presença de células gigantes multinucleadas $(\rightarrow)$, correspondente ao único animal do periodo de 60 dias que apresentava fragmentos da membrana. Em outro período (30 dias em B) é possível verificar a presença de tecidos normais. Aumento: A 40X; B 10X. Coloração hematoxilina-eosina.

Figura 13. Análise semiquantitativa da intensidade da inflamação nos dois grupos experimentais em função dos periodos experimentais.

Figura 14. Análise semiquantitativa da presença de polimorfonucleares nos dois grupos experimentais em função dos períodos experimentais.

Figura 15. Análise semiquantitativa da presença de Células Gigantes nos dois grupos experimentais em função dos periodos experimentais.

Figura 16. Análise semiquantitativa da proliferação angioblástica nos dois grupos experimentais em função dos periodos experimentais.

Figura 17. Análise semiquantitativa do grau de fibrosamento nos dois grupos experimentais em função dos períodos experimentais.

Figura 18. Gráfico representando os valores da atividade específica (AE) da enzima fosfatase ácida total (FAT) para os dois grupos nos diferentes periodos experimentais. Diferença entre os grupos tratados e não tratados em cada período(* $p<0,05)$.

Figura 19. Gráfico representando os valores da atividade específica (AE) da enzima fosfatase ácida lisossomal (FAL) para os dois grupos nos diferentes periodos experimentais. Diferença entre os grupos tratados e não tratados em cada período(* $p<0,05)$. 45

Figura 20. Gráfico representando os valores da atividade específica (AE) da enzima fosfatase ácida tartarato resistente (FART) para os dois grupos nos diferentes periodos experimentais. Diferença entre os grupos tratados e não tratados em cada periodo(* $p<0,05)$.

Figura 21. Gráfico representando os valores da atividade específica (AE) da enzima fosfatase ácida de baixa massa molecular relativa (PTP's) para os dois grupos nos diferentes periodos experimentais. Diferença entre os grupos tratados e não tratados em cada período $(* p<0,05)$.

Figura 22. Gráfico representando os valores da atividade específica (AE) da enzima fosfatase alcalina (Falc) para os dois grupos nos diferentes periodos experimentais. Diferença entre os grupos tratados e não tratados em cada periodo(* $p<0.01)$.

Figura 23. Gráfico representando os valores da atividade específica (AE) da enzima arilsulfatase (ARIL) para os dois grupos nos diferentes períodos experimentais. Diferença entre os grupos tratados e não tratados em cada periodo $(* p<0,05)$.

Figura 24. Gráfico representando os valores da atividade específica (AE) da enzima $\beta$-hexosaminidase $(\beta-$ hexo) para os dois grupos nos diferentes periodos experimentais. Diferença entre os grupos tratados e não tratados em cada periodo(* $p<0,05)$. 


\section{RESUMO}

O tratamento de defeitos ósseos tem sido um grande obstáculo para as áreas de ortopedia e odontologia, motivando inúmeros estudos na busca por técnicas ou substitutos ósseos adequados. Especificamente na odontologia, um problema comum é o crescimento do epitélio juncional da gengiva, que possui velocidade de proliferação maior que os tecidos constituintes do periodonto de sustentação (osso alveolar, ligamento periodontal e cemento), prejudicando a regeneração desses tecidos. No sentido de contornar essa dificuldade foi proposto a utilização de membranas ou barreiras biológicas para impedir o epitélio de proliferar e ocupar o espaço onde se deseja a regeneração periodontal, caracterizando a técnica denominada de Regeneração Tecidual Guiada (RTG). Nosso propósito foi avaliar histológica e bioquimicamente a resposta celular e absorção da membrana obtida de osso cortical bovino desmineralizado, impregnada ou não com tetraciclina, colocada em subcutâneo de ratos. Os períodos analisados foram de 1, 3, 7, 15, 30 e 60 dias após a colocação do material, usando um total de 120 animais. Os resultados histológicos mostraram para ambas membranas, uma resposta inflamatória de moderada à intensa nos períodos iniciais ( 1 e 3 dias), moderada nos períodos de 7 e 15 dias, e que diminuiu marcadamente nos dois períodos finais (30 e 60 dias). A reabsorção da membrana foi observada à partir de 15 dias pós-implantação, sendo que após 60 dias, apenas resquícios foram detectados em alguns animais. Os resultados da atividade enzimática mostrou diferenças entre os dois grupos nos períodos iniciais (1, 3 e 7 dias) indicando que a tetraciclina influenciou a resposta celular à membrana modificando a atividade das enzimas lisossomais. Concluímos que a membrana Gen-derm ${ }^{\circledR}$ mostrou-se bem tolerada pelos tecidos sendo completamente reabsorvida após 30-60 dias por células mononucleadas e células gigantes multinucleadas que desaparecem ao final do processo. A impregnação da membrana com tetraciclina não provocou nenhuma mudança histológica aparente, mas modificou significativamente a atividade específica das enzimas analisadas nos períodos iniciais, em particular das enzimas lisossomais. 


\section{Introdução}

Com a grande evolução científica e tecnológica que se deu nas últimas décadas, muito se tem descoberto a respeito de eventos fisiológicos, celulares e moleculares, proporcionando um melhor entendimento da relação gene-proteína-célula. Isso tem impulsionado diversos pesquisadores a usarem esses conhecimentos a seu favor. $\mathrm{Na}$ área de saúde, esses conhecimentos vêem ao encontro da ânsia de melhor se entender alguns fenômenos, tais como o mecanismo celular e molecular de algumas doenças, por vezes bem descritos, mas ainda não desvendados completamente. Muito se tem pesquisado (MISCH \& DIETSH, 1993) ${ }^{86}$ a respeito dos vários aspectos envolvidos na regeneração do tecido ósseo. Sabe-se que, apesar de seu grande poder de reparo, a resposta do organismo é insuficiente para que ocorra a regeneração do tecido em diversas situações como defeitos extensos (principalmente originados de acidentes), infecções (originadas de procedimentos incorretos, cistos ou mesmo em casos de doença periodontal), tumores e defeitos congênitos.

Um conceito claro na literatura é a necessidade de uma barreira mecânica que impeça a infiltração de células do tecido conjuntivo ou do epitélio no defeito ósseo, e que também proteja o coágulo sangüíneo nos estágios iniciais do reparo (MELCHER \& DREYER, 1962; FEINGOLD et al., 1977) ${ }^{10}$.

O princípio de selamento físico de um local anatômico para melhorar o reparo de um certo tipo de tecido e direcionar a regeneração tecidual já é descrita desde meados de 1950 (CAMPBELL \& BASSETT, 1956; HURLEY et al., 1959) ${ }^{10}$, porém o uso desse conceito para reparo de lesões na região bucal só ocorreu a partir de 1964 (BOYNE, 1964) ${ }^{10}$. Os conceitos de selamento anatômico para proteger o coágulo e barreira para impedir a invasão dos tecidos adjacentes foram empregados na periodontia para permitir a regeneração de todo o aparato de suporte do dente, sendo batizado de Regeneração Tecidual Guiada (RTG) por NYMAN et al. em $1982 .{ }^{90}$ Esses princípios também foram usados na recuperação de defeitos ósseos extensos (também chamados de defeitos ósseos perenes) sendo chamado de Regeneração Óssea Guiada (ROG).

Face à necessidade, diversas barreiras foram desenvolvidas, produzidas e testadas sendo classificadas em membranas absorvíveis e não absorvíveis. A mais conhecida e utilizada dentre as não absorvíveis é a membrana de politetrafluoretileno expandido (PTFEe), 
patenteada com o nome de "Gore-Tex", cuja eficiência foi demonstrada em diversos trabalhos (PECORA et al., 1995; PIETTE et al., 1995) ${ }^{102,103 .}$

Segundo WINDISCH et al. (1999) ${ }^{143}$ as membranas absorvíveis clinicamente não acrescentam melhoras quando comparadas com as membranas não absorvíveis. Entretanto, a utilização de membranas absorvíveis permite eliminar um dos inconvenientes do uso de membranas não absorvíveis que é a necessidade de uma segunda cirurgia para sua remoção, proporcionando um menor tempo operatório, maior aceitação por parte do paciente e redução dos riscos de perda de nova inserção (WANG \& MACNEIL, 1998) ${ }^{139}$.

A possibilidade de associar fatores de crescimento às membranas absorvíveis (PITARU et al., 1994; CHEN et al., 1997) ${ }^{107,26}$ tem encorajado o seu uso em detrimento das membranas não absorvíveis. Esse material tem sido cada vez mais usado em conjunto com materiais para enxertos ósseos melhorando assim os resultados clínicos, principalmente no tratamento de defeitos intra-ósseos periodontais, lesão de furca e deiscências (WANG \& MACNEIL, 1998; BUNYARATAVEJ \& WANG 2001; PAOLANTONIO, 2002) ${ }^{139,22,98}$. O uso de membranas em cirurgia parendodôntica, onde a perda óssea é acentuada e o reparo pode ser prejudicado pela proliferação do tecido conjuntivo dentro do sitio cirúrgico, devido, muitas vezes, à comunicação endo-periodontal poderia proporcionar resultados satisfatórios (LEONARDIS et al., 1999) ${ }^{79}$.

As lesões infectadas ou contaminadas, particularmente lesões periodontais, representam um desafio adicional à terapia de lesões ósseas. Sabemos que certas bactérias da cavidade oral têm a capacidade de colonizar e acelerar o processo de degradação dessas membranas (SBORDONE et al., 1999) ${ }^{119}$, como por exemplo a Porphyromonas gingivalis (CHEN et al., 1997; WAKABAYASHI et al., 1996) ${ }^{26,138}$. Como o uso da tetraciclina tem sido muito difundido em procedimentos periodontais para descontaminação da área e auxiliar na regeneração dos tecidos periodontais perdidos (ALGER et al., 1990; DRURY \& YUKNA, 1991; ROSENBERG \& ROSE, 1998; DELAISSE et al., 2000; HOUSER et al., 2001) 2, 41, 112, 36, 63 , parece bastante lógico utilizá-la associada a membranas absorvíveis.

A tecnologia para a produção desse tipo de material com propriedades osteopromotoras estava restrita a países do $1^{\underline{0}}$ mundo. Recentemente a industria nacional superou esta limitação e lançou no mercado brasileiro uma membrana derivada da matriz orgânica bovina desmineralizada, a qual vem sendo largamente utilizada na clínica odontológica, pois apresenta custo acessível e qualidade clínica comprovada (SANCHES et 
al., 2000; HERCULANI, 2000) ${ }^{116,60}$. Contudo, a despeito do importante papel que este tipo de membrana desempenha nas cirurgias ósseas, (PECORA et al., 1995; SCULEAN et al., 1999; HERCULIANI et al., 2000 ${ }^{102,122,60}$, os eventos biológicos envolvidos neste processo de reparo ainda não são completamente conhecidos (GALGUT et al., 1991) ${ }^{51}$. Como exposto na literatura, os mecanismos celulares e moleculares envolvidos na degradação de barreiras absorvíveis não são completamente conhecidos.

Assim, o objetivo geral deste trabalho foi aprofundar os conhecimentos relativos à resposta celular à membrana de osso cortical bovino desmineralizado, associado ou não à tetraciclina. O modelo experimental utilizado foi a implantação no tecido subcutâneo de ratos e, após diferentes períodos experimentais, biópsias foram coletadas para análise microscópica e bioquímica, através da dosagem de enzimas lisossomais. 


\section{Revisão de Literatura:}

Com o objetivo de facilitar a compreensão dos diversos fatores envolvidos neste trabalho, apresentaremos algumas considerações a respeito do material a ser analisado e as ferramentas utilizadas para avaliação e comparação do material.

\subsection{Colágeno como Biomaterial}

A palavra colágeno provém do grego:"kolla", que significa cola, e "gen”, que significa origem. O colágeno é uma proteína fibrosa formada por três cadeias polipeptídicas em tripla hélice chamadas cadeias $\alpha$. Sendo este um dos principais constituintes da matriz extracelular de vários tecidos. Existem cerca de 19 tipos de colágeno, dos quais os mais

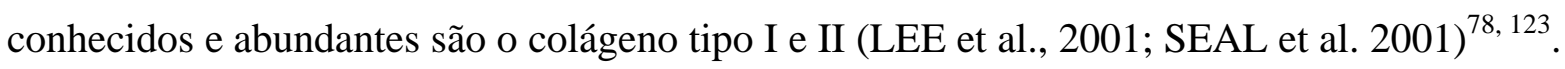

O colágeno representa a principal macromolécula extracelular do tecido conjuntivo periodontal. Cerca de $90 \%$ do colágeno humano é do tipo I, o qual é encontrado principalmente em ossos e pele, sendo o colágeno do tipo II o maior constituinte da cartilagem. O osso é um tecido denso, uma forma especializada de tecido conjuntivo que consiste basicamente de uma matriz orgânica (90\% dela é composta de colágeno tipo I) e uma matriz inorgânica, composta basicamente por hidroxiapatita (DELAISSE et al., 2000; SEAL et al. 2001) $)^{36,123}$.

Os colágenos tipo I, II, III e V tem extensas secções de seqüências homólogas independentes da espécie (LEE et al., 2001) ${ }^{78}$. Segundo alguns autores este material apresenta baixo potencial imune quando implantado em animais e humanos (HYDER et al., 1992; BENQUÉ et al. 1997) ${ }^{66,11}$, sendo por isso aprovado pela "Food and Drug Administration" $(\text { FDA })^{139}$ para uso clínico. Os vários tipos de colágenos mostraram ser quimiotáticos para fibroblastos humanos, absorvíveis fisiologicamente pelos tecidos, possuem propriedades hemostáticas, servem de suporte (material carreador) para crescimento celular na engenharia de tecidos, disponibilidade e abundância na natureza, fácil manuseio podendo ser modelados em diversas formas, (WANG \& MCNEIL, 1998; LEE et al., 2001) ${ }^{139,77}$ apresentam, ainda, afinidade por outros polímeros sintéticos (RACHLIN et al., 1996; LI \& WOZNEY, 2001) ${ }^{108,}$ 80

$\mathrm{Na}$ odontologia o colágeno tem sido usado como material para fabricação de membranas ou barreiras biológicas, empregadas nas técnicas de regeneração tecidual guiada 
(AL-ARRAYED et al., 1995) ${ }^{1}$ e regeneração óssea guiada (BUNYARATAVEJ \& WANG 2001) ${ }^{22}$, devido à sua biocompatibilidade e por ser absorvível (PITARU et al., 1988; PITARU et al., 1989; BLACK et al., 1994; ZITZMANN et al., 1997; PARODI et al., 1997; ROCHA et al, 2002; WANG et al., 2002) $)^{105,106,14,148,99,111,140 .}$

$\mathrm{Na}$ degradação do colágeno estão envolvidas várias enzimas, no entanto as principais são as enzimas chamadas de colagenases, que são especializadas em hidrolisar o colágeno.

As colagenases pertencem a família das enzimas chamadas de metaloproteinases da matriz (MMPs), essas formam uma grande família de enzimas zinco dependentes responsáveis pela degradação do tecido conjuntivo (BORD et al., 1996) ${ }^{18}$. Recentemente foi demonstrada sua ação em momentos da modelação e remodelação óssea (BORD et al., 1996) 18. As MMPs foram primeiramente descritas em 1962 por Gross e Lapierre (GREENWALD et al., 1998) ${ }^{54}$. Somente as MMP-1 e MMP-8 podem clivar o colágeno tipo I. Essas colagenases podem ser produzidas por diversos tipos celulares, entre elas estão os fibroblastos, macrófagos, células epiteliais e osteoclastos, bem como por algumas bactérias que estão presentes na cavidade oral como a Porphyromonas gingivalis (WANG \& MCNEIL, $1998)^{139}$.

\subsection{Tetraciclina}

A tetraciclina é um antibiótico bem conhecido pelo seu amplo espectro de ação sobre as bactérias. Este antibiótico e seus análogos (são no mínimo nove), têm sido investigados nos últimos anos por outras características que estão envolvidas na inibição da ação das MMPs (GREENWALD et al., 1998; DELAISSE et al., 2000) ${ }^{54,36}$. Especificamente na periodontia a tetraciclina está sendo estudada quanto a seu papel na regulação da expressão das MMPs (alguns tipos de tetraciclinas comerciais podem inibir no mínimo 5 tipos de MMPs: MMP-1, 2, $-8,-9$ e -13 , possivelmente a -12, GREENWALD et al., 1998) ${ }^{54}$ em vários tipos celulares envolvidos na doença periodontal (KIM et al., 2002) ${ }^{73}$. Seu uso consagrado em procedimentos periodontais, onde seu desempenho mais efetivo e poderoso se faz através da aplicação tópica deste antibiótico na superfície da raiz dental com a finalidade de auxiliar a regeneração dos tecidos periodontais de sustentação perdidos devido a doença periodontal (FRIESEN et al, 2002; HARRIS 2002) ${ }^{48,59}$. A aplicação deste antibiótico, ou seus similares, na superfície tratada tem como objetivos a descontaminação e desmineralização de uma pequena área, expondo colágeno (STERRET et al., 1997) ${ }^{128}$ a fim de estimular a regeneração dos tecidos 
perdidos, aumentando consideravelmente o tecido conjuntivo aderido a raiz do dente e novo cemento formado (ALGER et al., 1990; DRURY \& YUKNA, 1991; ROSENBERG \& ROSE, 1998; DELAISSE et al., 2000; HOUSER et al., 2001) 2, 41, 112, 36, 63 . Outros trabalhos, como de HARRIS $\left(1997,1998\right.$ e 2002) ${ }^{57-59}$, preconizaram a tetraciclina associada a biomateriais para o tratamento de defeitos periodontais, sendo aceito como uma técnica muito efetiva em conjunto com a RTG.

Estudos in vitro e in vivo têm relatado o potencial da tetraciclina e seus análogos na indução da produção de matriz óssea por osteoblastos (incluindo síntese de novo colágeno), inibição a função dos osteoclastos (SASAKI et al., 1991) ${ }^{117}$, ou mesmo indução de apoptose em osteoclastos (BETTANY et al., 2000) ${ }^{13}$.

\subsection{Enzimas como Biomarcadores}

Diversos processos fisiológicos e patológicos podem ser monitorados através de marcadores biológicos ou, em outras palavras, biomarcadores. Processos envolvendo a degradação ou remodelação tecidual freqüentemente estão associados à atividade de lisossomos, os quais contém 40 ou mais enzimas como fosfatase ácida, arilsulfatase, ßhexosaminidase e proteases (BASSETTO et al., 2001) ${ }^{8}$.

Alguns relatos na literatura têm avaliado a possibilidade das fosfatases e enzimas lisossomais servirem como marcadores biológicos na tentativa de conhecer em maior detalhe os mecanismos celulares e moleculares envolvidos na resposta à implantação de biomateriais seja através da dosagem da atividade fosfatase nos tecidos reacionais adjacentes ao material implantado (OLIVEIRA et al., 1999; SICCA et al., 2000) ${ }^{94,125}$, ou através de métodos de imunohistoquímicos (OHNISHI et al., 2000) ${ }^{93}$.

As arilsulfatases são enzimas que catalisam a hidrólise de ésteres sulfatos aromáticos (DRAPER et al., 1976) ${ }^{39}$, com a formação de um composto fenólico e um íon sulfato $\left(\right.$ NICHOLLS \& ROY, 1971) ${ }^{89}$. Essas enzimas estão presentes em diversas bactérias e praticamente todos os tecidos de mamíferos estudados (DODGSON \& SPENCER, 1957; ROY \& JERFY, 1970; ROY, 1971; NICHOLLS \& ROY, 1971) 38, 113, 114, 89 onde participam de diversos processos biológicos como a fertilização, mobilização de ácido ascórbico, renovação de mielina e reestruturação do tecido conjuntivo (FAROOQUI \& MANDEL, $1977)^{46}$. 
Desde há muito sabe se que a atividade das arilsulfatases aumenta na urina e outros fluídos biológicos em diversas condições fisiológicas, como gravidez, principalmente no $3^{\circ}$ trimestre (BAKONSKA-PACON et al., 1999), e patológicas, como nos processos inflamatórios, tumores malignos (DZIALOSZYNKI \& GNIOT-SZULZYCKA, 1967) ${ }^{42}$, linfomas malignos, câncer de cólon, tumores malignos do sistema nervoso central (LAIDLER et al., 1991; HONKE et al., 1995) ${ }^{75,62}$, leucemias mieloblástica e linfoblástica (OMER et al., 1994) ${ }^{95}$, e no alcoolismo crônico (ALVAREZ-LEAL et al., 2000) ${ }^{3}$. Também nos casos de hiperplasia cística e adenocarcinoma de endométrio a atividade da arilsulfatase nos tecidos mostrou-se aumentada (VITAIOLI et al., 1994) ${ }^{135}$. Sabe-se também que o conteúdo de carboidratos das arilsulfatases produzidas por células tumorais apresenta aumentos na sialação, fosforilação e sulfatação (NAKAMURA et al., 1984; WAHEED \& VAN ETTEN, $1985)^{87,137}$, embora estes eventos ainda não sejam bem compreendidos. Essas enzimas também têm sido utilizadas como biomarcadores para doenças do periodonto (LAMSTER et al., 1988; PAGE, 1992; ELEY \& COX, 1998) ${ }^{76,96,45}$, podendo ser observados níveis elevados da enzima em lesões crônicas do periodonto (KHAYAT et al., 2001) ${ }^{72}$.

A B-hexosaminidase é uma enzima residente no lisossomo e participa da degradação de glicoproteínas, glicolipídios e glicosaminoglicanas. Seu papel é hidrolisar o resíduo terminal de $\mathrm{N}$-acetil-glicosamina e $\mathrm{N}$-acetil-galactosamina. A relativa simplicidade de seu mecanismo catalítico contrasta com o elaborado sistema para sua inserção no lisossomo. Mutações podem levar à ausência ou funcionamento incorreto da enzima, resultando no acúmulo de seus substratos, com conseqüências particularmente danosas para o sistema nervoso. As características estruturais desta enzima e seu papel no tratamento de gangliosidoses podem ser revistas em NEUFELD (1989) ${ }^{93}$ e CHAVANY \& JENDOUBI $(1998)^{23}$.

A fosfatase ácida constitui uma grande classe de monofosfohidrolases amplamente distribuída na natureza e que também existe sob diversas formas isoenzimáticas em um mesmo tecido, isoformas estas distintas quanto à massa molecular relativa (Mr), especificidades quanto aos substratos, sensibilidade a inibidores, ponto isoelétrico (pI), presença e número de carboidratos ligados à cadeia polipeptídica.

De maneira geral, as fosfatases ácidas de mamíferos podem ser classificadas em 4 classes, de acordo com a Mr e sua localização subcelular, a saber: FAc-I, 200,0 kDa, associada à fração microssomal; FAc-II, 100,0 kDa, de origem lisossomal; FAc-III, 40,0 kDa 
e FAc-IV, de 8,0 a 18,0 kDa, ambas solúveis no citoplasma (FILBURN, 1973; ARAÚJO, MIES \& MIRANDA, 1976; BAXTER \& SUELTER, 1984; GRANJEIRO et al., 1997; BUZALAF et al., 1998) $)^{47,5,9,52,23}$.

Porém, quanto às características físico-químicas e cinéticas podem ser enquadras em 3 grupos, resumidos na tabela 1. As fosfatases ácidas de alto peso molecular (AMr, > 100,0 $\mathrm{kDa}$ ), normalmente são inibidas por tartarato e fluoreto e insensíveis a agentes bloqueadores de grupos -SH. As fosfatases ácidas de baixo peso molecular (BMr, <20,0 kDa) atualmente denominadas de proteínas tirosina fosfatases de BMr (PTP de BMr, GRANJEIRO et al., 1997) $)^{53}$, apresentam grupos -SH reduzidos próximos ou no sítio ativo, implicados no mecanismo de catálise, sendo completamente inibidas por agentes bloqueadores de grupos SH, metais pesados, mas são insensíveis ao tartarato e fluoreto. Tanto a fosfatase ácida de AMr com a BMr são independentes de metais e exibem, em relação às outras classes, uma maior especificidade quanto ao substrato. Uma terceira classe de fosfatases ácidas compreende as enzimas de peso molecular intermediário (IMr, entre 30,0 e 60,0 kDa). Apresentam uma baixa especificidade quanto a substratos embora se possa identificar uma atividade significativa sobre nucleosídeos fosfatados, piridoxal-5-fosfato, ß-glicerofosfato e $\mathrm{NADP}^{+}$. A sensibilidade ao tartarato e fluoreto é variável, mas íons metálicos e pHMB interferem fracamente (PANARA; ANGIOLILLO \& PASCOLINI, 1989; VINCENT \& AVERILL, 1990) $)^{97,134}$.

Tabela 1 - Distribuição das Fosfatases ácidas em mamíferos.

\begin{tabular}{|c|c|c|c|}
\hline $\begin{array}{l}\text { Fosfatases Ácidas } \\
\text { (Mamíferos) }\end{array}$ & $\mathrm{Mr}^{*}$ & Inibidor & Localização \\
\hline $\mathrm{AMr}$ & $>100 \mathrm{kDa}$ & $\mathrm{NaF}$, Tartarato & $\begin{array}{l}\text { Membrana Celular } \\
\text { Lisossomos }\end{array}$ \\
\hline $\mathrm{IMr}$ & $30-70 \mathrm{kDa}$ & $\begin{array}{l}\text { Tartarato - resistente } \\
\text { Tartarato - sensível }\end{array}$ & Citoplasma \\
\hline $\mathrm{BMr}$ & $<18 \mathrm{kDa}$ & pHMB & Citoplasma \\
\hline
\end{tabular}

$\mathrm{Mr}^{*}=$ massa molecular relativa

Estudos recentes demonstraram fortemente a relação entre PTPs de BMr e o controle do ciclo celular (CHIARUGI et al., 2000) ${ }^{28}$. Em 1993, STEFANI et al., utilizando peptídeos sintéticos contendo fosfotirosina, relataram uma atividade hidrolítica preferencial sobre um 
peptídeo análogo ao sítio de fosforilação do receptor do fator de crescimento derivado de plaquetas (PDGF-r) ${ }^{127}$. A autofosforilação de receptores de fatores de crescimento tem sido apontada como um passo crucial na promoção da proliferação celular induzida por sinais mitogênicos. Além disso, um maior estímulo na atividade tirosina quinase e/ou uma modificação no nível da atividade celular da PTP tem sido demonstrada em transformações neoplásicas. Isto levou alguns pesquisadores a supor que a superexpressão de algumas PTPs poderia suprimir ou mesmo reverter a transformação celular, até mesmo utilizando as PTPs de BMr. Em 1995 CHIAGURI et al., relataram que a superexpressão da PTP de BMr mutante e inativa (Cys-12(Ser)) proporcionava um aumento no nível de autofosforilação do PDGF-r, sendo que as células ainda apresentavam um alto nível de proliferação ${ }^{27}$.

Células de origem mesenquimal, que estão ativamente envolvidas na digestão intra e/ou extracelular, bem como células epiteliais, apresentam elevados níveis de atividade da fosfatase ácida. A distribuição e propriedades da FAc de células de origem mesenquimal, indicam uma inter-relação entre células mononucleadas e multinucleadas ativamente envolvidas em algum processo digestivo (EGGERT \& GERMAIN, 1980) ${ }^{43}$. No interior celular são encontradas invariavelmente nos lisossomos (sendo considerada como um marcador), mas também no citoplasma (ARAÚJO, MIES \& MIRANDA, 1976) ${ }^{5}$ e, segundo alguns autores, nos microssomos (LIN \& FISHMAN, 1972) ${ }^{81}$, aparelho de Golgi (COLEMAN; SCHOFIELD \& MCDONALD, 1980) ${ }^{35}$ e membrana celular (HIMENO et al, $1991)^{61}$.

A fosfatase ácida tartarato resistente (FATR) é uma metalo-glicoproteína rica em manose (SAUNDERS et al., 1985) ${ }^{118}$ sintetizada por células diferenciadas do sistema monohistiocítico. Pode ser encontrada em leucócitos, macrófagos alveolares e derivados de monócitos. Está localizada na membrana celular e em organelas intracelulares (KRAENZLIN

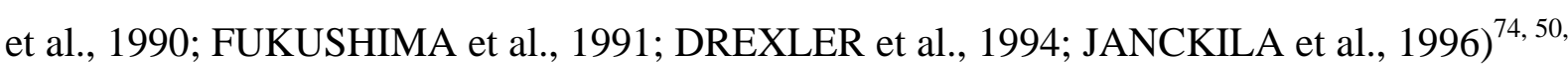
40, 67. A FATR originada de osteoclastos tem sido proposta como um marcador para a reabsorção óssea associada ao osteoclasto e para o próprio osteoclasto, podendo ser utilizada para o diagnóstico ou acompanhamento da terapia (RICO \& VILA, 1993; BULL et al., 1999) ${ }^{110,21}$. Contudo, a identidade e função biológica de seu substrato natural ainda não foram determinadas. Recentemente HALLEN et al., $(1998)^{58}$ propuseram que o principal papel da FATR in vivo seria atuar como uma proteína tirosina fosfatase, regulada pelos estado redox de seu núcleo metálico, e estaria relacionada com o controle do ciclo celular. 


\subsection{Barreiras Biológicas}

Segundo WANG et al. (1998) ${ }^{139}$ a terapia periodontal tem 2 objetivos principais: 1) redução ou eliminação da inflamação tecidual induzida pela placa bacteriana e seus subprodutos; 2) correção dos defeitos ou problemas anatômicos causados pelo processo da doença. Tendo em vista o segundo objetivo, varias técnicas cirúrgicas foram estabelecidas para tentar regenerar parcial ou totalmente os tecidos perdidos na doença periodontal avançada.

Técnicas cirúrgicas foram recomendadas, para inibir o crescimento de tecidos adjacentes que possam substituir de forma danosa os tecidos perdidos. Principalmente em relação ao tecido epitelial que apresenta velocidade de crescimento maior que o tecido conjuntivo (CATON \& ZANDER, 1976) ${ }^{10}$.

Desde então, diversos trabalhos aplicaram o conceito de proteção mecânica do coágulo, funcionando realmente como uma barreira física dando assim estabilidade ao coágulo. MELCHER $(1976)^{10}$ parece ter sido o primeiro a sugerir as bases do princípio de regeneração tecidual no periodonto, afirmando que as células progenitoras do periodonto (ligamento e cemento) residem no ligamento periodontal e/ou osso alveolar remanescente ao redor do dente.

NYMAN et al. (1982) $)^{90}$ foram os primeiros a usar membranas em estudo para controlar a regeneração do periodonto. Baseados na teoria de que as células provenientes do ligamento periodontal são as únicas com potencial de diferenciarem-se em cementoblastos, eles usaram membranas não absorvíveis para atuar como barreira impedindo a migração de fibroblastos da gengiva e células epiteliais sobre a raiz desnuda, permitindo o repovoamento seletivo pelas células do ligamento periodontal restante.

Depois deste período inicial de trabalhos mostrando a vantagem de se usar a técnica de regeneração tecidual guiada (RTG), os trabalhos tem focado a produção de membranas compostas por materiais absorvíveis para eliminar a segunda etapa cirúrgica exigida para a remoção de membranas não absorvíveis, como as membranas de PTFEe e de acetato de celulose (PARODI et al., 1997) ${ }^{99}$.

Assim, outros materiais vêm sendo testados com o objetivo de encontrar um material biocompatível e com características adequadas de tempo que permaneceria nos tecidos, fácil manuseio e bons resultados clínicos. Dentre os materiais absorvíveis mais pesquisados, o 
colágeno conquistou seu espaço, pois representa a principal macromolécula extracelular do tecido conjuntivo periodontal.

Há alguns anos o FDA aprovou o uso de colágeno xenogênico (obtido principalmente de bovinos) como material para uso clínico. Freqüentemente o colágeno é obtido do couro do animal ou do tendão. Contudo, a confecção de barreiras a partir desse tipo de colágeno com vistas à RTG exige tratamento químicos à base de glutaraldeído, por exemplo, a fim de aumentar o número de ligações cruzadas do colágeno e, por conseguinte, o tempo de permanência no tecido e dificultar a passagem de células (ROCHA et al., 2002) ${ }^{111}$. Uma alternativa inédita no mundo todo é utilizar o osso bovino desmineralizado, cuja parte orgânica é constituída principalmente por colágeno tipo I densamente organizado (TAGA et al., 1997; TAGA et al., 1997; BENOIT NÚÑEZ, 1999) $)^{130,131,10 .}$

Segundo alguns autores este material apresenta baixo potencial imune quando implantado em animais e humanos (HYDER et al., 1992; BENQUÉ et al. 1997, DELAISSE et al., 2000; SEAL et al. 2001) $66,11,36,123$. Os vários tipos de colágeno mostraram ser quimiotáticos para fibroblastos humanos, são absorvíveis fisiologicamente pelos tecidos, possuem propriedades hemostáticas, servem de suporte (material carreador) para crescimento celular na engenharia de tecidos, disponibilidade e abundância na natureza, são de fácil manuseio podendo ser modelados em diversas formas, (WANG \& MCNEIL, 1998; LEE et al., 2001) ${ }^{139,78}$ tendo ainda afinidade por outros polímeros sintéticos (RACHLIN et al., 1996; LI \& WOZNEY, 2001) ${ }^{108,80}$, possuem afinidade por diversos fatores de crescimento como as BMPs (BARBOZA et al., 2000; MATSUMOTO et al., 2001; LI \& WOZNEY, 2001; CHOI et

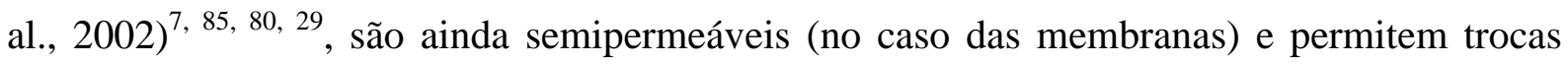
gasosas (WANG \& MCNEIL, 1998) ${ }^{139}$.

$\mathrm{Na}$ odontologia o colágeno tem sido usado como material para fabricação de membranas ou barreiras biológicas, empregadas nas técnicas de regeneração tecidual guiada (AL-ARRAYED et al., 1995) $^{1}$ e regeneração óssea guiada (BUNYARATAVEJ \& WANG $2001)^{22}$. Tendo sido descrita a sua biocompatibilidade tecidual e propriedade de ser absorvida pelos tecidos do hospedeiro, tanto em animais como em humanos (PITARU et al., 1988; PITARU et al., 1989; BLACK et al., 1994; TAGA et al., 1997; ZITZMANN et al., 1997; PARODI et al., 1997; ROCHA et al, 2002; WANG et al., 2002) 105, 106, 14, 131, 148, 99, 111, 141.

Pesquisas em animais, utilizando os materiais de membrana, são importantes à medida que fornecem subsídios para o entendimento da resposta tecidual frente ao implante desses 
materiais. GALGUT et al (1991) ${ }^{51}$ testaram vários tipos de membranas, de diferentes compostos (Gore-tex, Millipore filter, membranas de ácido polilático e uma membrana de um polímero de hidroxibutirato/hidroxivalerato), em transcutâneo de ratos. A resposta celular aos materiais foi variada, com predominância de monócitos para todos os materiais. Houve, entretanto uma grande tendência de persistir inflamação aguda com PMN com a membrana ePTFE (Gore-tex) que com qualquer outro material. A membrana da Gore-tex foi associada com uma tendência maior de infiltrado inflamatório e formação de cápsula fibrosa precoce talvez pela sua característica de relativa hidrofobicidade.

Trabalhando com defeitos intra-ósseos em tíbia de ratos, ROCHA et al. $(2002)^{11}$ preencheram esses defeitos com matriz de colágeno tipo I bovino. No grupo controle os defeitos criados foram preenchidos com o próprio coágulo sangüíneo do animal. Os achados desse estudo mostraram a biocompatibilidade da matriz de colágeno em tecido ósseo e capacidade osteocondutora, comparados ao grupo controle.

Outros modelos animais foram usados para verificar a qualidade e segurança desses materiais (PITARU et al. 1989; COLANGELO et al., 1993; CIRELLI et al., 1997) ${ }^{106,34,33} \mathrm{em}$ condições de perda de tecido periodontal. Trabalhos clínicos mostraram a importância da presença da barreira física nas técnicas de RTG e ROG (PITARU et al., 1987; BLUMENTHAL, 1988; CHUNG et al., 1990; PAUL et al., 1992) ${ }^{105,15,31,101}$. Estudos clínicos demonstraram que as membranas absorvíveis foram tão eficientes para a RTG quanto os não absorvíveis, tendo sido utilizada a membrana de PTFEe, considerada como material padrão (BLACK et al., 1994; YUKNA \& YUKNA, 1996) ${ }^{14,146}$ ou por vezes até melhores que os materiais não absorvíveis (BLUMENTHAL et al., 1993) ${ }^{16}$. 


\section{Proposição}

O objetivo geral deste trabalho foi aprofundar os conhecimentos relativos à resposta celular à membrana de osso cortical bovino desmineralizado, associado ou não à tetraciclina. O modelo experimental utilizado foi à implantação no tecido subcutâneo de ratos e, após diferentes períodos experimentais, biópsias foram coletadas para análise microscópica e bioquímica, através da dosagem de enzimas lisossomais. A membrana derivada do osso cortical bovino desmineralizado é um biomaterial existente exclusivamente no Brasil e sua biocompatibilidade e eficiência clínica foram anteriormente relatadas (TAGA et al., 1997 e BENOIT NÚÑEZ, 1999) ${ }^{131,10}$. Assim, os objetivos específicos neste trabalho são:

Identificar e analisar semiquantitativamente, nos diferentes períodos experimentais, quais os tipos celulares que estão presentes no tecido adjacente às membranas, e qual o tipo de interação entre elas.

Avaliar o efeito da adsorção de tetraciclina à membrana com relação à resposta celular e o tempo de degradação.

Correlacionar os achados comparativamente entre os dois grupos experimentais quanto à resposta celular e tempo de degradação.

Determinar a atividade específica de fosfatases ácidas, da fosfatase alcalina, da arilsulfatase e a $\beta$-hexosaminidase, nos tecidos reacionais induzidos pela membrana de cortical óssea bovina, nos diferentes períodos experimentais. 


\section{Material e Métodos}

\subsection{Grupos Experimentais}

As membranas absorvíveis testadas neste trabalho (Figura 1) foram obtidas a partir de osso cortical bovino, completamente processado, livre de células, lipídios e proteínas imunogênicas. Os blocos de osso cortical foram desmineralizados e lâminas com cerca de 400 $\mu \mathrm{m}$ foram obtidas. Detalhes sobre os procedimentos para obtenção da membrana são informações proprietárias da empresa Baumer S.A., que forneceram as membranas. As membranas de osso cortical bovino desmineralizada são constituídas principalmente de colágeno tipo I (95\%) e traços de fatores de crescimento, como BMPs. Os grupos experimentais avaliados neste estudo foram:

Membrana derivada do osso cortical bovino desmineralizado (M) sem a adição de tetraciclina (Gen-derm®, Baumer S.A., Registro no Ministério da Saúde: 103.455.00007) (Figura 1);

Membrana derivada do osso cortical bovino desmineralizado associado à tetraciclina (MT) (Baumer S.A.) (Figura 1).
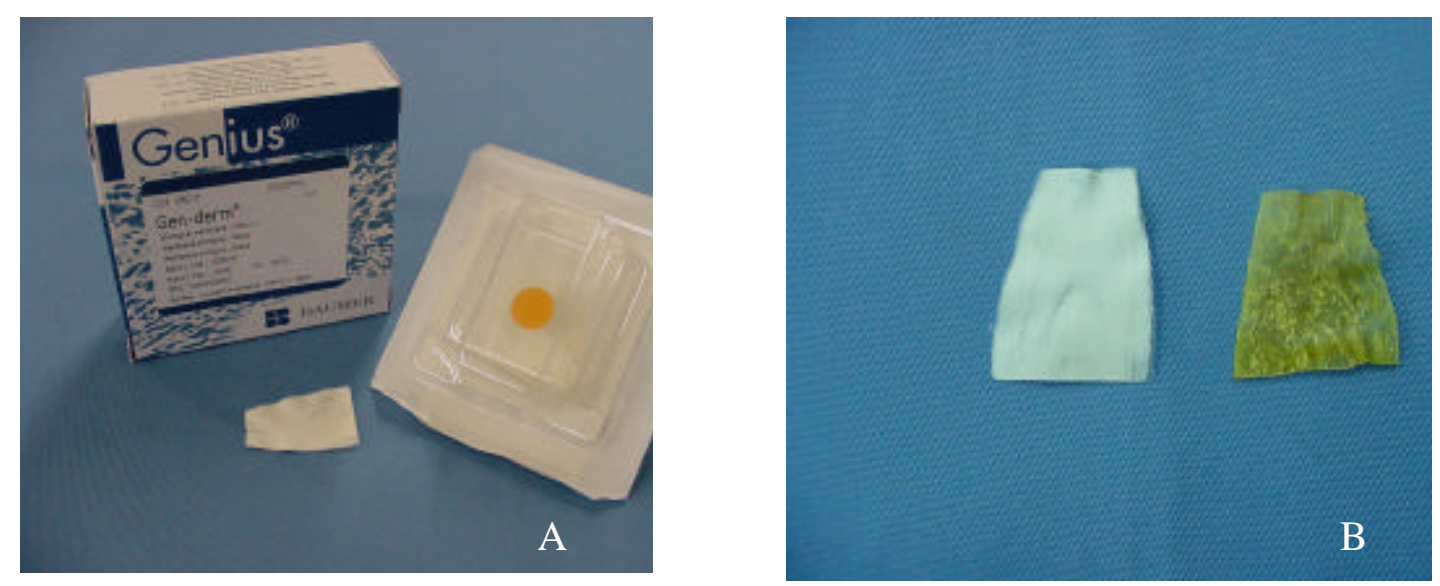

Figura 1. A) Embalagem comercial da Gen-derm ${ }^{\circledR}$; B) Aspecto macroscópico da Genderm ${ }^{\circledR}$ à esquerda e Gen-derm® tratada com tetraciclina à direita.

\subsection{Preparo dos animais e procedimentos de implantação}

Um total de 120 ratos albinos da linhagem wistar (Rattus norvegicus), machos adultos (aproximadamente 70 dias de vida e peso aproximado de $250 \mathrm{~g}$, provenientes do Biotério Central da Faculdade de Odontologia de Bauru - Universidade de São Paulo), foram divididos aleatoriamente em dois grupos de 60 animais cada, os quais foram mortos 1, 3, 7, 15, 30 e 60 
dias após a implantação da membrana $(n=10)$. A pesquisa foi realizada segundo as normas recomendadas pela Comissão de Ética no Ensino e Pesquisa em Animais da Faculdade de Odontologia de Bauru - USP (Anexo 1).

Em todos os animais a mesma sequiência operatória foi seguida, sendo que, inicialmente, os animais foram anestesiados com uma mistura de Dopalen (Agribrands do Brasil Ltda, Paulínia - SP) + Anasedan (Agribrands do Brasil Ltda, Paulínia - SP) na proporção 1:1 (v/v) 0,5 ml por Kg de peso, aplicados via intramuscular. Quando os animais ficaram imóveis, estes foram colocados sobre um campo operatório esterilizado e imobilizados para o ato operatório.

$\mathrm{Na}$ área dorsal dos animais, seguindo a linha sagital, realizamos a tricotomia, expondo a pele, seguida da assepsia com gaze embebida em álcool iodado. Utilizando bisturi com lâmina $n^{\circ} 10$ (Becton-Dickson, São Paulo) fizemos duas incisões retas na pele desses animais, no centro da região dorsal, no sentido látero-lateral entre as patas anteriores do animal, uma do lado esquerdo e outra do lado direito, com aproximadamente $1,5 \mathrm{~cm}$ de extensão, expondo o tecido conjuntivo subcutâneo. As margens das incisões foram então afastadas por pinças e, utilizando uma tesoura de ponta romba, o tecido conjuntivo foi divulsionado em sentido anterior do animal para a colocação das membranas. Foram colocadas duas membranas por animal (60 animais do grupo com a Gen-derm® e outros 60 do grupo da Gen-derm® + tetraciclina), sendo o tecido reacional de uma delas utilizado para a análise microscópica e a outra para a análise enzimática (Figura 2).

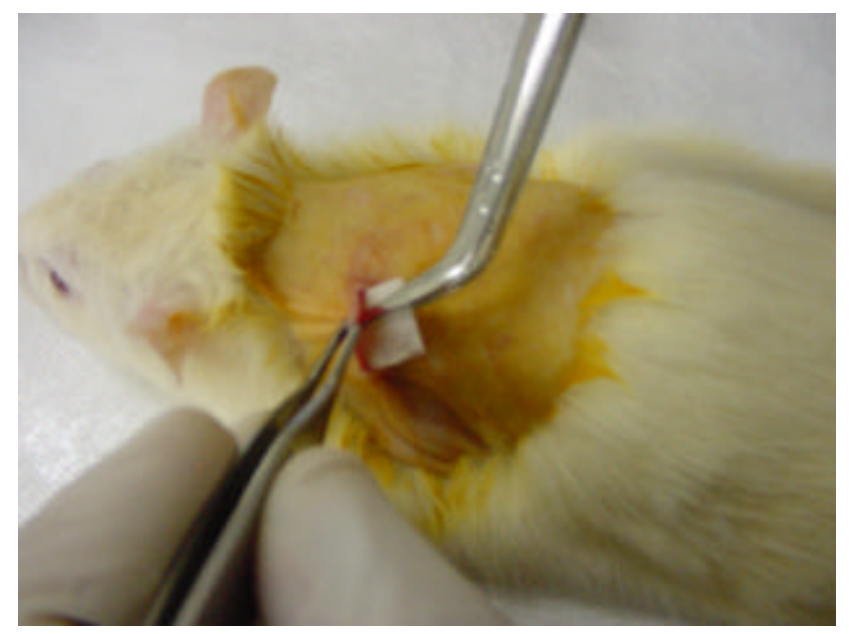

Figura 2. Implantação da membrana no tecido subcutâneo. 
Durante o ato operatório a membrana foi cortada com $1 \mathrm{~cm}$ de lado utilizando-se régua endodôntica metálica e tesoura esterilizadas. As membranas foram então umedecidas em solução isotônica de cloreto de sódio $0,9 \%(\mathrm{~m} / \mathrm{v})$ e, em seguida, implantadas no tecido conjuntivo subcutâneo. As membranas foram esterilizadas previamente por radiação gama (25 KGy).

Uma vez implantadas as membranas, as margens da ferida foram aproximadas e a sutura descontínua (fio de seda 4.0) foi realizada para uma perfeita coaptação. Saliente-se que as bordas da ferida ficaram distantes das lojas que continham os materiais. Após o término da sutura, uma gaze embebida em uma solução de álcool iodado foi passada sobre a área.

Por todo o período experimental os animais permaneceram nas dependências do Biotério Central da Faculdade de Odontologia de Bauru - Universidade de São Paulo, e receberam dieta normal "ad libitum" composta de ração e água, sendo mantidos em gaiolas com forragem de maravalha, a qual foi substituída regularmente.

\subsection{Obtenção das biópsias e preparo histotécnico}

Decorridos os períodos experimentais particulares a cada grupo de animal, estes foram novamente anestesiados, nova tricotomia foi realizada na região dorsal, assim como a assepsia da pele. Novas incisões foram realizadas para se obter acesso ao tecido conjuntivo. Tais procedimentos foram executados de forma idêntica à fase cirúrgica inicial para a implantação dos materiais.

A localização dos materiais foi feita visualmente, pela palpação e, então, foram removidas pequenas peças das áreas dos implantes e os tecidos circunjacentes, sendo 1 amostra para análise microscópica e outra para dosagem de enzimas. Em seguida os animais foram submetidos à eutanásia pelo deslocamento cervical, seguindo as normas do Colégio Brasileiro de Experimentação Animal (COBEA).

Imediatamente após a remoção das biópsias, estas foram imersas em formalina $10 \%$ tamponada por um período de 24 horas para a fixação dos tecidos. Após este período, as biópsias foram lavadas em água corrente por 5 horas. Todas as peças foram incluídas em parafina, cortadas com uma espessura de $6 \mu \mathrm{m}$ com navalhas descartáveis (Jung-Reichardt, Alemanha), e coradas com hematoxilina-eosina segundo a técnica convencional. 


\subsection{Microscopia (análise semiqualitativa):}

A resposta tecidual foi analisada em função das alterações inflamatórias (presença de edema, alterações vasculares e infiltrado inflamatório) e dos processos reparatórios (grau de fibrosamento, proliferação angioblástica e fibroblástica) encontrados nos tecidos que envolvem os materiais implantados. Foram atribuídos escores (de zero a três), subjetivamente, a cada estrutura analisada sem que o examinador soubesse previamente qual material estava sendo analisado.

\subsection{Obtenção das Amostras (Extratos)}

O tecido coletado foi pesado imediatamente após sua remoção e depois foi mantido congelado a uma temperatura de $-20^{\circ} \mathrm{C}$, no momento da dosagem enzimática a amostra foi descongelada e homogeneizada em tampão acetato $0,1 \mathrm{M}, \mathrm{pH} 5$, contendo EDTA e $\beta$ mercaptoetanol $1 \mathrm{mM}$ e centrifugada a $10.000 \mathrm{rpm}$ durante 30 minutos. O sobrenadante constituiu o extrato a ser utilizado para a quantificação de proteína e da atividade enzimática das diferentes isoformas da fosfatase ácida (através da inibição diferencial por tartarato, fluoreto, e p-hidroximercuribenzoato (pHMB)), da arilsulfatase e $\beta$-hexosamidase (enzimas lisossomais). O precipitado foi ressuspendido em tampão Tris- $\mathrm{HCl}$ 0,1M, pH 7,5 (contendo Triton $\mathrm{X}-100$ 0,2\%, $\mathrm{MgCl}_{2} 2 \mathrm{mM}$ e $\mathrm{NaCl} 150 \mathrm{Mm}$ ). Após 30 minutos à temperatura ambiente, a solução ressuspendida foi centrifugada a $12000 \mathrm{rpm}$ durante 20 minutos e o sobrenadante foi utilizado para a quantificação da fosfatase alcalina. Um esquema do processo de homogenização e obtenção do extrato estão resumidos no quadro a seguir (Figura 3). 
Tecido Reacional

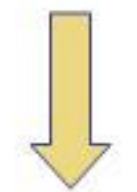

Tampão Acetato $0,1 \mathrm{M} / \mathrm{pH} 5,0$ gelado

$(1: 4, \mathrm{~m} / \mathrm{v})$

EDTA e $\beta$-Mercaptoetanol $1 \mathrm{mM}$

Triturar no gelo

Homogeneizado

(Centrifugação $12.000 / 30 \mathrm{~min} / 4^{\circ} \mathrm{C}$ )

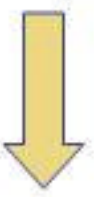

Precipitado

(Ressuspender em Tris-HCl

$0,1 \mathrm{M} / \mathrm{pH} 7,5$, Triton $\mathrm{X}-100 \mathrm{0}, 2 \%$

$\mathrm{MgCl}_{2} 2 \mathrm{mM}, \mathrm{NaCl}$

$150 \mathrm{mM}$ )

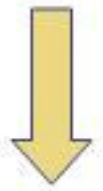

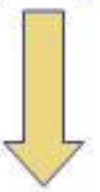

Sobrenadante (extrato)

Quantificar

Proteina

FAT

FART

FAL

FABMr

Aril

$\beta$-Hexo

Agitação 30 min, temperatura ambiente

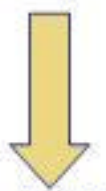

Centrifugação $12.000 / 30 \mathrm{~min} / 4^{\circ} \mathrm{C}$

\勺

Precipitado(descarte)

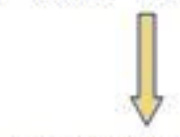

Sobrenadante quantificar $\left\{\begin{array}{l}\text { Proteina } \\ \text { FAlc }\end{array}\right.$

Figura 3. Protocolo para extração e dosagem de atividade das fosfatases ácidas, arilsulfatase, B-hexosaminidase e alcalina. 


\subsubsection{Determinação de proteína}

A proteína foi quantificada pelo método de Bradford como descrito anteriormente (BRADFORD, 1976) ${ }^{19}$ utilizando a albumina do soro bovino como padrão.

\subsubsection{Determinação da atividade fosfatásica}

\subsubsection{Fosfatase Ácida Solúvel}

Fosfatase Ácida Total (FAT): Para um volume final de 1,0 ml, a reação foi iniciada pela adição de $50 \mu \mathrm{l}$ do extrato a um meio contendo $100 \mathrm{mM}$ de tampão acetato de sódio, $\mathrm{pH}$ 5,0 , e $5 \mathrm{mM}$ do p-nitrofenilfosfato (pNPP). A paralisação ocorreu pela adição de $1,0 \mathrm{~mL}$ de $\mathrm{NaOH}$ 1,0 M, após incubação por $10 \mathrm{~min}$ a $37^{\circ} \mathrm{C}$. Nos controles a enzima foi adicionada após a colocação do $\mathrm{NaOH}$ (GRANJEIRO et al., 1997) ${ }^{52}$.

A formação do p-Nitrofenol foi determinada espectrofotometricamente pela leitura da absorção a $405 \mathrm{~nm}$ (espectrofotômetro Ultrospec 2000), tomando-se o valor de $18.000 \mathrm{M}^{-1}$ $\mathrm{cm}^{-1}$ como coeficiente de extinção molar da forma do p-nitrofenóxido (CHAIMOVICH \& NOME, 1970) ${ }^{24}$.

Fosfatase Ácida Resistente ao Tartarato (FART): O ensaio foi realizado como descrito acima, exceto pela adição de p-hidroximercuribenzoato (pHMB,1 mM) e Tartarato $(10 \mathrm{mM}) . \mathrm{O}$ pHMB inibe toda atividade da fosfatase ácida de baixo peso molecular (FABMr) e a atividade residual na presença do tartarato foi correspondente a FART.

Fosfatase Ácida Lisossomal (FAL): O ensaio foi realizado como descrito acima, exceto pela adição de p-hidroximercuribenzoato (pHMB), um potente inibidor da FABMr (GRANJEIRO et al., 1997) ${ }^{53}$. A atividade obtida foi subtraída da Atividade FART uma vez que esta enzima não é inibida pelo pHMB.

Fosfatase Ácida de Baixa Massa Molecular Relativa (FABMr): O ensaio foi realizado como descrito acima, exceto pela adição de Tartarato e Fluoreto. Inibidores das fosfatases de alto e médio peso molecular.

\subsubsection{Determinação da Fosfatase Alcalina de Membrana (FAlc)}

A atividade enzimática foi determinada a $37^{\circ} \mathrm{C}$, através da formação do p-nitrofenol (coeficiente de extinção molar de $18.000 \mathrm{M}^{-1} \mathrm{~cm}^{-1}$, em $\mathrm{pH}$ alcalino), utilizando-se o tampão glicina $25 \mathrm{mM}, \mathrm{pH} 9,4$, contendo $2 \mathrm{mM}$ de $\mathrm{MgCl}_{2}$ e $1 \mathrm{mM}$ de p-nitrofenilfosfato em um 
volume final de 1,0 mL, de acordo com CIANCAGLINI et al. (1992) ${ }^{32}$. A reação foi iniciada pela adição de $0,05 \mathrm{~mL}$ da amostra obtida como indicado na Figura 3.

Em todos os ensaios, uma unidade de atividade enzimática (UE) foi definida como a quantidade de enzima necessária para produzir $1 \mu \mathrm{mol}$ de $\mathrm{p}$-Nitrofenol por minuto. A atividade enzimática específica (AE) é expressa como unidade de atividade enzimática por miligrama de proteína $(\mathrm{AE}=\mathrm{UE} / \mathrm{mg})$.

\subsubsection{Determinação da arilsulfatase}

A atividade da arilsulfatase foi determinada pelo método descrito por WAHEED \& VAN ETTEN (1979) $)^{136}$. O extrato foi incubado em meio de reação contendo $1,0 \mathrm{ml}$ de pnitrocatecol-sulfato $5 \mathrm{mM}$ em tampão acetato $0,05 \mathrm{M}, \mathrm{pH}$ 5,0. Após 30 minutos a reação foi paralisada pela adição de 1,0ml de $\mathrm{NaOH}$ 1,0 M. A absorbância foi determinada pela leitura da cor do comprimento de onda de $515 \mathrm{~nm}$. A unidade de atividade enzimática é definida como a quantidade de enzima que hidrolisa um $\mu$ mol de substrato por minuto, sendo o coeficiente de extinção molar do p-nitrocatecol de $1,24 \times 10^{4} \mathrm{M}^{-1} \mathrm{~cm}^{-1}$.

\subsubsection{Determinação da â-hexosaminidase}

A determinação da B-hexosaminidase foi realizada pelo método descrito por TAGA $(1984)^{129}$. O extrato foi incubado em meio de reação contendo $1,0 \mathrm{ml}$ de p-nitrofenil-N-acetilß-D-glucosaminida $3 \mathrm{mM}$ em tampão acetato $0,05 \mathrm{M}, \mathrm{pH} 4,5$ a $37^{0} \mathrm{C}$. Após incubação por 20 minutos a reação foi paralisada pela adição de 1,0ml de $\mathrm{NaOH}$ 1,0 M.

Uma unidade de atividade enzimática é definida como 1 micromol de p-nitrofenol liberado por minuto, sendo o coeficiente de extinção molar $1,8 \times 10^{4} \mathrm{M}^{-1} \mathrm{~cm}^{-1}$, no comprimento de onda de $405 \mathrm{~nm}$.

\subsection{Análise Estatística}

A análise estatística foi realizada utilizando o programa InStat ${ }^{\circledR}$ (GraphPad Software, Inc.), utilizando um teste não paramétrico (análise estatística por Kruskal Wallis). 


\section{Resultados}

Durante todo período pós-operatório, os animais se mantiveram saudáveis e nenhum deles apresentou sinais de edema, supuração ou exposição da membrana.

Para facilidade de apresentação e compreensão os resultados obtidos foram dividido em 4 partes:

- Análise microscópica da resposta celular à membrana de osso cortical bovino desmineralizado.

- Análise microscópica da resposta celular à membrana de osso cortical bovino desmineralizado associada à tetraciclina.

- Estudo comparativo do efeito da adsorção de tetraciclina na degradação da membrana de osso cortical bovino desmineralizado.

- Determinação do perfil de fosfatases e enzimas lisossomais durante a bioabsorção da membrana de osso cortical bovino desmineralizado.

\subsection{Análise microscópica da resposta celular à membrana de osso cortical bovino implantada em subcutâneo de ratos}

\subsubsection{Período de 1 dia:}

Em todos animais da amostra $(\mathrm{n}=10)$, a membrana estava presente e aparentemente íntegra. Neste período notamos um infiltrado inflamatório moderado formado, predominantemente, por polimorfonucleados (PMNs), presença de edema com rede de fibrina. Este tecido inflamado estava bem restrito circunscrevendo a membrana. Notamos neste período uma vasos congestos próximos ao material (figura 4A).

\subsubsection{Período de 3 dias:}

Neste período a membrana pôde ainda ser identificada em todos os espécimes ainda aparentemente íntegra, com apenas alguns sinais discretos de início de degradação. Contudo, o infiltrado inflamatório era de moderado a intenso na maioria das amostras. O infiltrado celular ao redor da membrana era composto por PMNs e linfócitos. Comparativamente às amostras do período anterior, observou-se um maior número de vasos e capilares nos tecidos próximos a membrana (figura 4B). 


\subsubsection{Período de 7 dias:}

A membrana se encontrava íntegra, porém já apresentava sinais de uma sutil degradação com fendas (Figura 5), exceto em um animal que foi descartado da análise porque apresentava a membrana dobrada no tecido subcutâneo. Um exuberante tecido de granulação foi visível neste período, sendo formado por células mononucleadas. O número de vasos encontrado foi relativamente maior em relação aos períodos anteriores (Figura 5) e notamos a presença de células gigantes em contato com a membrana, principalmente localizadas nas extremidades da membrana.

\subsubsection{Período de 15 dias:}

Observamos, sinais nítidos de destruição da membrana na maioria dos casos (Figura 6). Em uma houve intensa destruição, restando apenas pedaços da membrana; em outra a membrana estava íntegra. Um infiltrado inflamatório crônico leve ainda foi perceptível, no entanto menor quando comparados aos períodos anteriores. $\mathrm{O}$ tecido de granulação está mais evoluido neste período, com maior grau de fibrosamento, proliferação fibroblástica e angioblástica em relação aos períodos anteriores (Figura 6). Um grande número de células gigantes estava presente ao redor da membrana em todas as amostras.

\subsubsection{Período de $\mathbf{3 0}$ dias:}

Apenas 4 amostras com a presença da membrana em estágio avançado de degradação (Figura 7) foram observadas, nas outras amostras a membrana ou seus indícios não foram encontrados. Nas amostras exibindo fragmentos da membrana havia a presença de macrófagos e células gigantes em contato com o material (Figura 7B), essas amostras apresentavam um tecido de granulação com presença de PMNs provavelmente para concluir a absorção do material implantado. Nas amostras onde não foram encontradas as membranas o tecido apresentava-se normal sem nenhuma alteração significativa, indicando a completa absorção da membrana.

\subsubsection{Período de 60 dias:}

Presença de pequenos fragmentos da membrana foram encontrados apenas em 3 amostras. Nas outras amostras, os tecidos estavam aparentemente normais, não sendo encontrado qualquer sinal da membrana, sugerindo a completa absorção do material (Figura 
8). Quando da presença de resquícios da membrana observamos macrófagos e células gigantes ao seu redor, e um discreto fibrosamento e presença de vasos. 

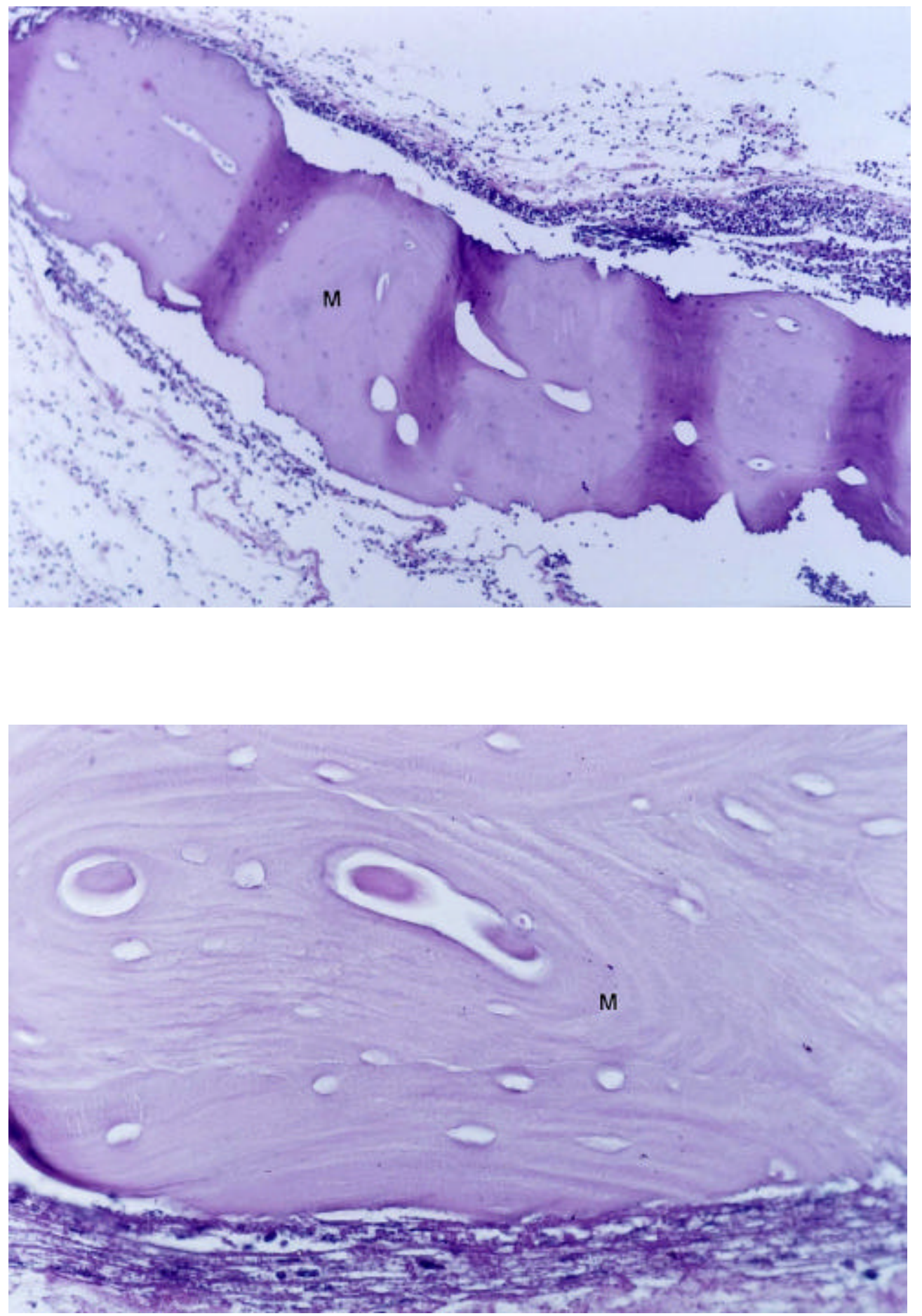

Figura 4. Fotomicrografia do período de 1 e 3 dias. Em A (1 dia) a membrana (M) apresentava-se aparentemente intacta. Em B (3 dias) a membrana (M). Aumento: A 10X; B 40X. Coloração hematoxilina-eosina. 

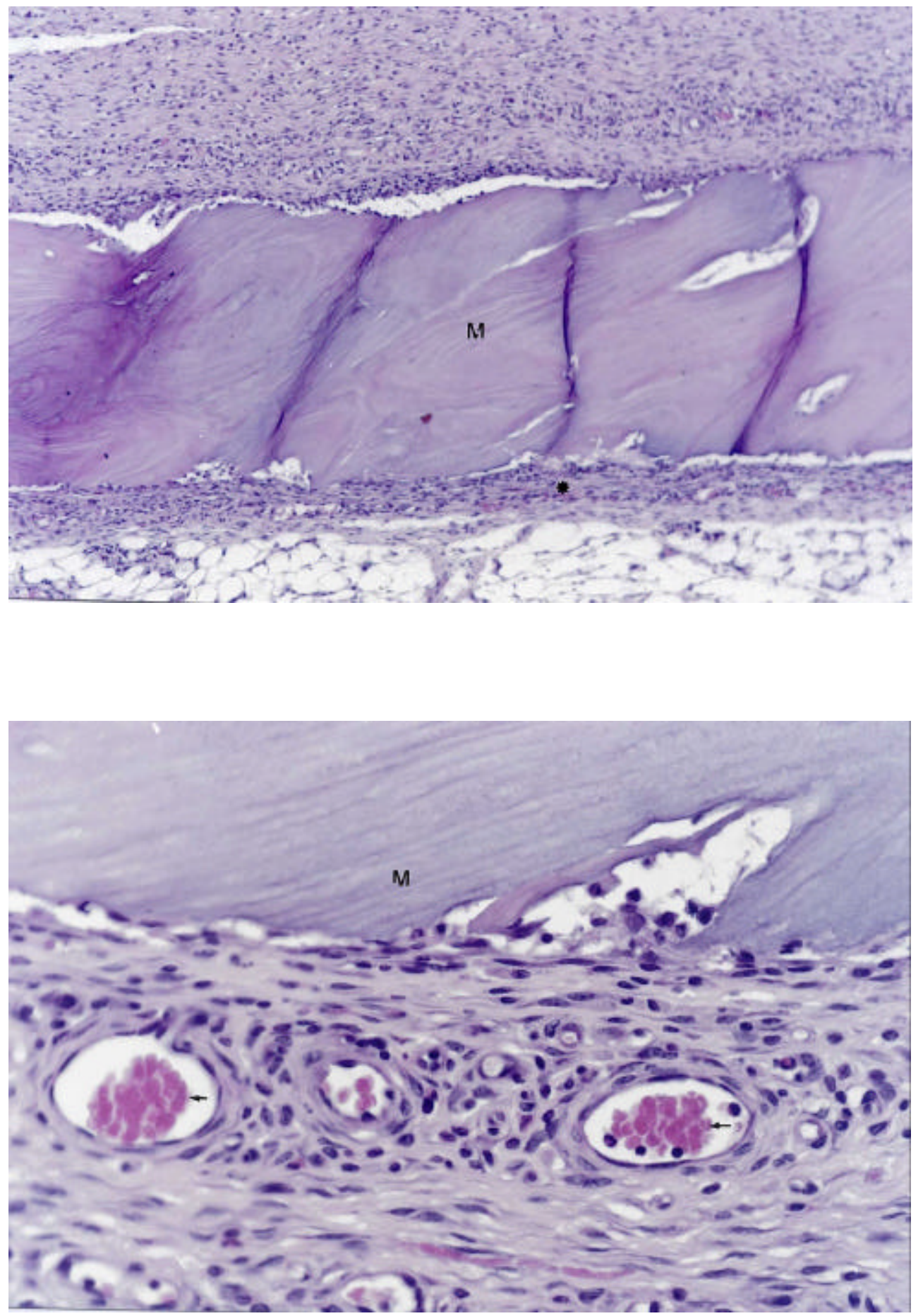

Figura 5. Fotomicrografia do período de 7 dias. Neste período a membrana (M, em A) apresenta-se aparentemente intacta e envolta por células mononucleadas (*). Em maior aumento $(\mathrm{B})$ é possível distinguir pequenos vasos $(\rightarrow)$ bem próximos à margem da membrana (M). Aumento: A 10X; B 40X. Coloração hematoxilina-eosina. 

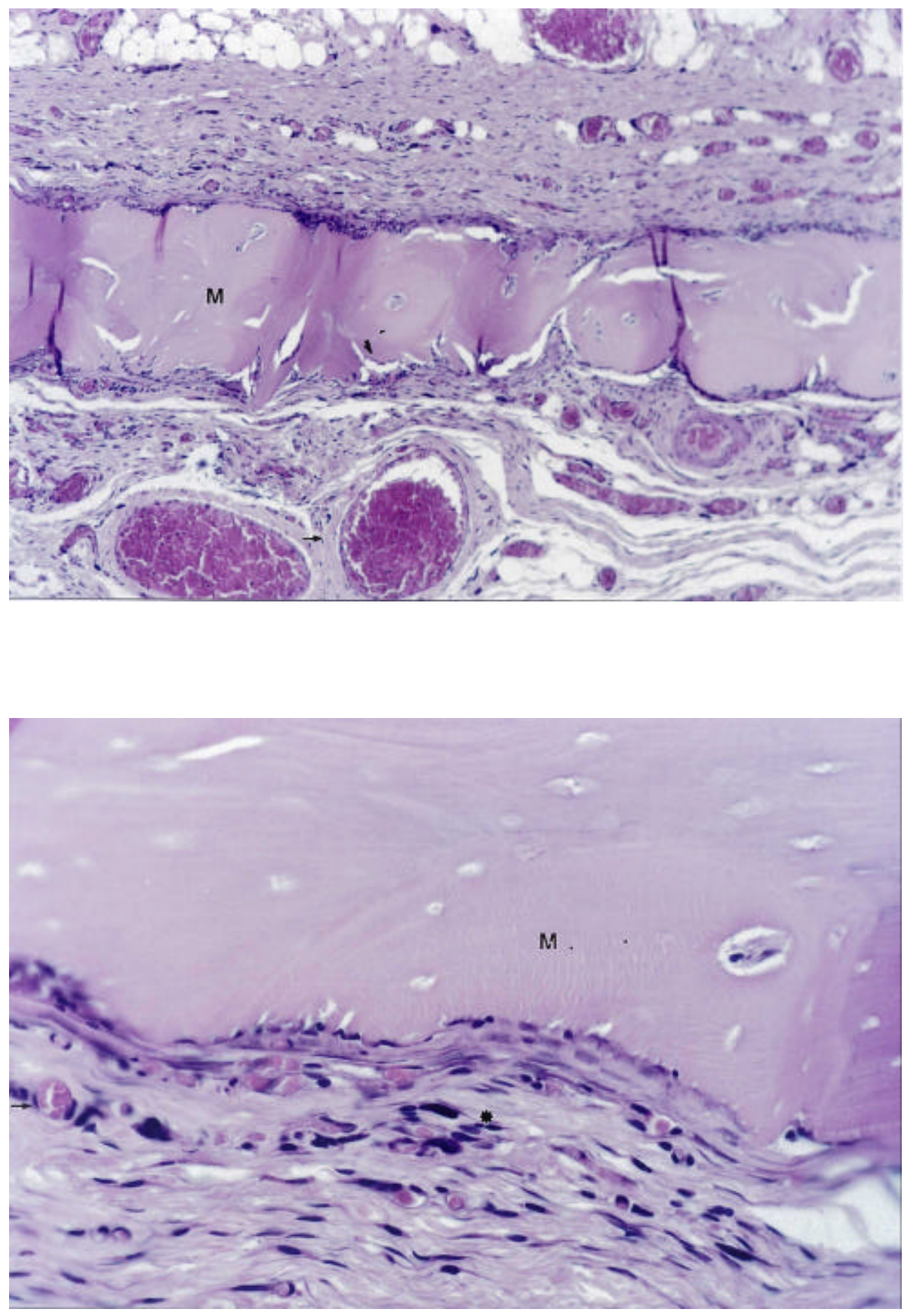

Figura 6. Fotomicrografia do período de 15 dias. Neste período a membrana (M, em A) apresenta-se com sinais de invasão e degradação ( ), cercada de células mononucleadas (*) oriundas dos tecidos adjacentes, presença de inúmeros vasos congestos $(\rightarrow)$. Em maior aumento $(\mathrm{B})$ é possível distinguir pequenos vasos $(\rightarrow)$ bem próximos à margem da membrana (M). Aumento: A 10X; B 40X. Coloração hematoxilina-eosina. 

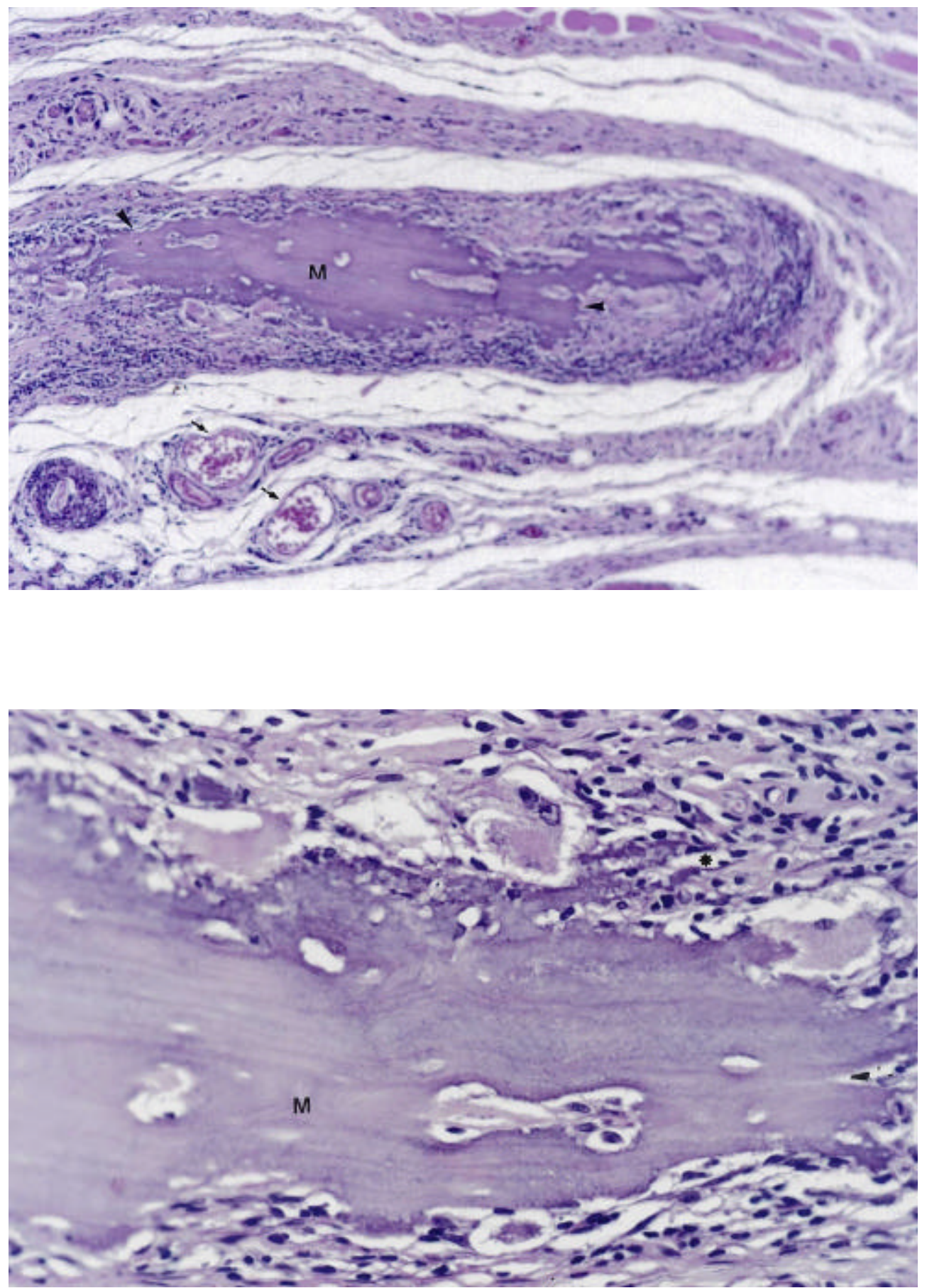

Figura 7. Fotomicrografia do período de 30 dias. Neste período notamos os fragmentos da membrana (M, em A) sinais de degradação ( ), presença de vasos $(\rightarrow)$. Em maior aumento (B) é possível observar a membrana (M) sendo invadida por células mononucleadas (*). Aumento: A 10X; B 40X. Coloração hematoxilina-eosina. 

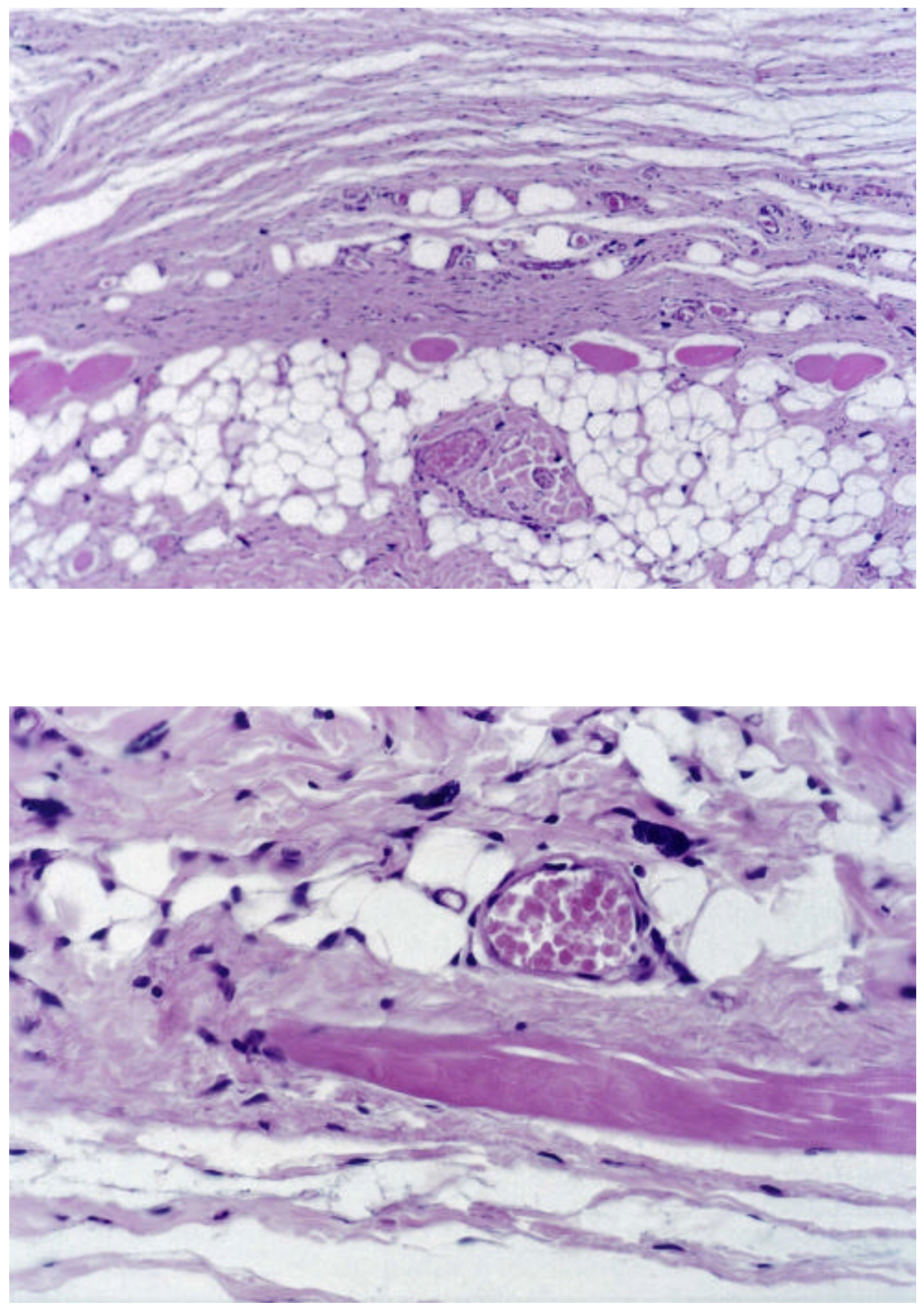

Figura 8. Fotomicrografia do período de 60 dias. Neste período não encontramos os fragmentos, ou sinais da membrana (em A) ou (B, maior aumento). Havia apenas tecidos normais sem sinais da membrana. Aumento: A 10X; B 40X. Coloração hematoxilina-eosina. 


\subsection{Análise microscópica da resposta celular à membrana de osso cortical bovino desmineralizado tratada com tetraciclina implantada em subcutâneo de ratos}

\subsubsection{Período de 1 dia:}

A membrana estava presente e aparentemente íntegra em todas as amostras. Em uma ela se apresentava dobrada, sendo descartada. Um infiltrado inflamatório de moderado a intenso, formado principalmente por PMNs estava circunscrito ao redor da membrana. Havia neste período vasos congestos próximos à membrana (Figura 9A).

\subsubsection{Período de 3 dias:}

$\mathrm{Na}$ maioria dos casos analisados, a membrana encontrava-se aparentemente íntegra sem sinal visível de degradação. Em um caso havia nitidamente em degradação. O infiltrado inflamatório era moderado na maioria das amostras. $\mathrm{O}$ infiltrado celular ao redor da membrana era composto por PMNs e linfócitos(Figura 9B). Neste período observamos vasos e capilares nos tecidos próximos à membrana.

\subsubsection{Período de 7 dias:}

A membrana se encontrava praticamente íntegra em todas amostras (Figura 10), exceto em um animal cuja membrana exibia sinais de mais avançada degradação. Um animal foi descartado da análise porque apresentava a membrana dobrada no tecido subcutâneo. Neste momento existe a formação de um tecido de granulação jovem, composto por células mononucleadas, fibrosamento e pequenos vasos. O número de vasos encontrado foi relativamente maior em relação aos períodos anteriores (Figura 10).

\subsubsection{Período de 15 dias:}

Neste período havia nítida destruição da membrana na maioria dos casos, exceto em um onde estava praticamente íntegra (Figura 11). O infiltrado inflamatório era leve, menor quando comparados aos períodos anteriores, com presença discreta de PMNs. Observou-se aumento no grau de fibrosamento associado à maior proliferação fibroblástica e de pequenos vasos, em relação aos períodos anteriores (Figura 11). Grande número de células gigantes estavam presentes ao redor da membrana em todas as amostras estudadas. 


\subsubsection{Período de $\mathbf{3 0}$ dias:}

Não foi observado qualquer indício da membrana e o tecido apresentava-se aparentemente normal e sem qualquer alteração, indicando absorção completa da membrana (Figura 12).

\subsubsection{Período de 60 dias:}

Como no período anterior também não foram encontrados sinais da membrana (Figura 12), exceto em um dos animais onde foram observados resquícios da membrana em avançado estado de degradação. 

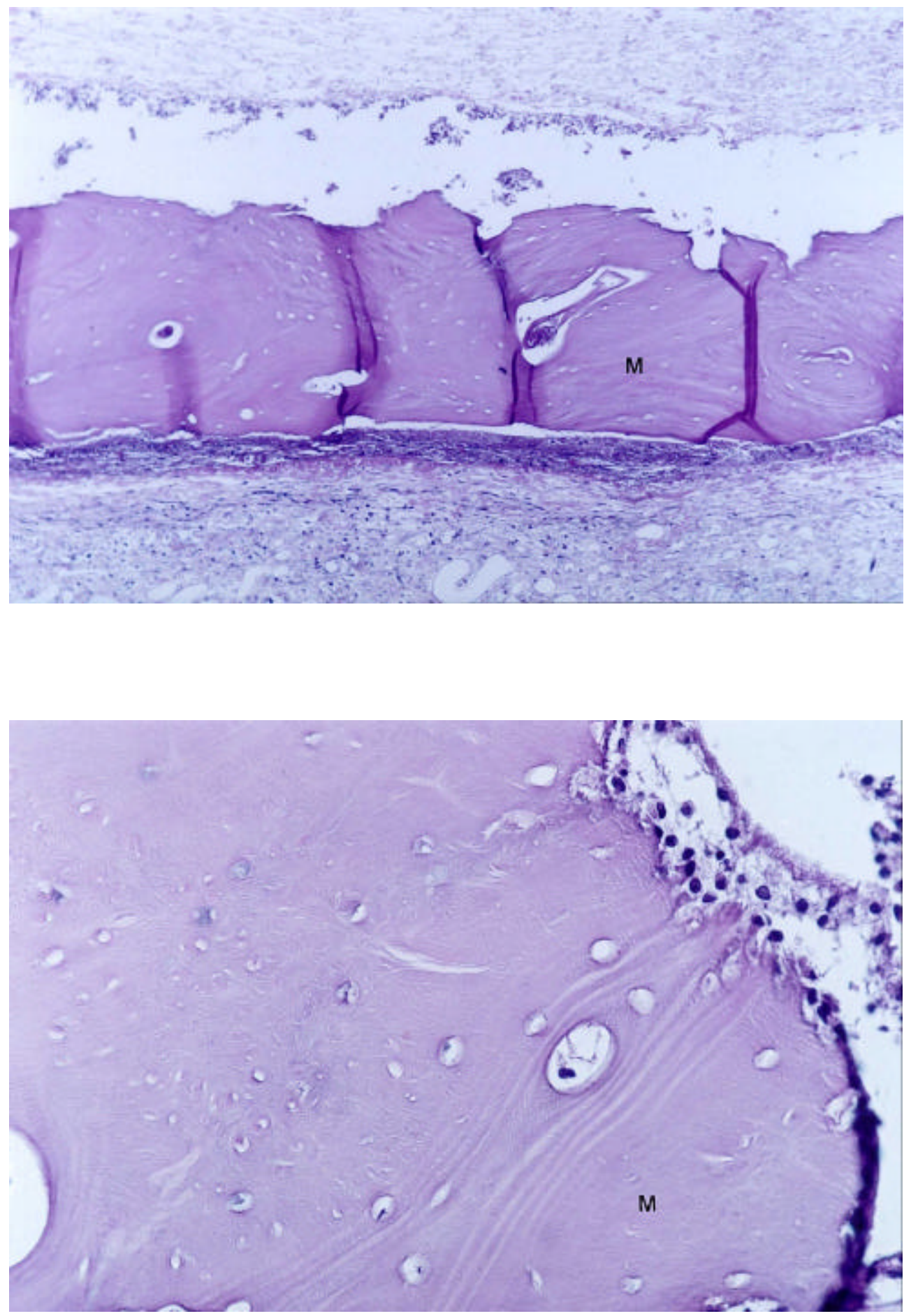

Figura 9. Fotomicrografia do período de 1 e 3 dias. Em A (1 dia) a membrana (M) apresentava-se aparentemente intacta. Em B (3 dias) a membrana (M). Aumento: A 10X; B 40X. Coloração hematoxilina-eosina. 

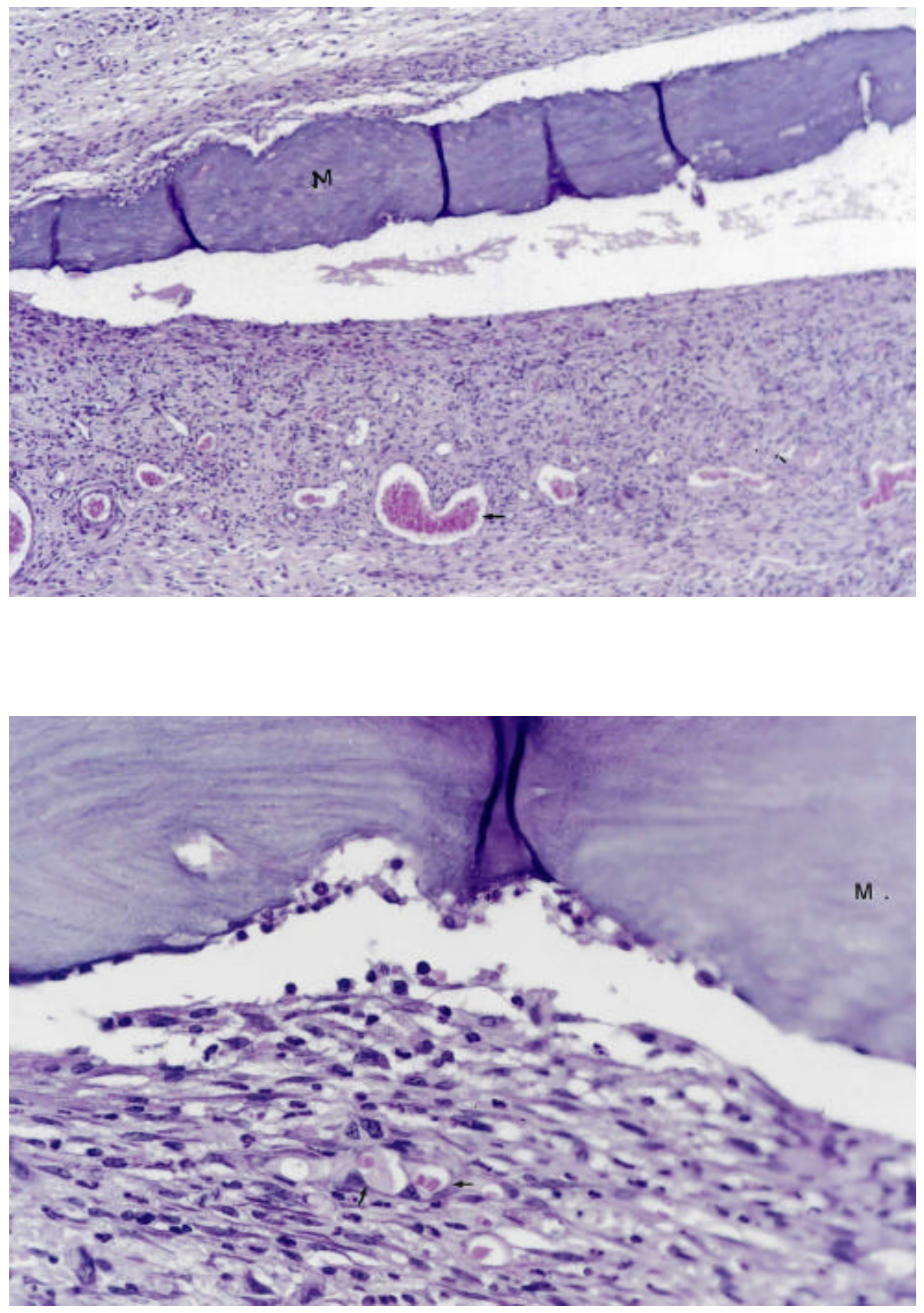

Figura 10. Fotomicrografia do período de 7 dias. Neste período a membrana (M em A) apresentava-se aparentemente intacta, notamos ainda a presença de vasos no tecido de granulação adjacente à ela $(\rightarrow)$. Em maior aumento $(B)$ é possível distinguir pequenos vasos $(\rightarrow)$ bem próximos à margem da membrana (M). Aumento: A 10X; B 40X. Coloração hematoxilina-eosina. 

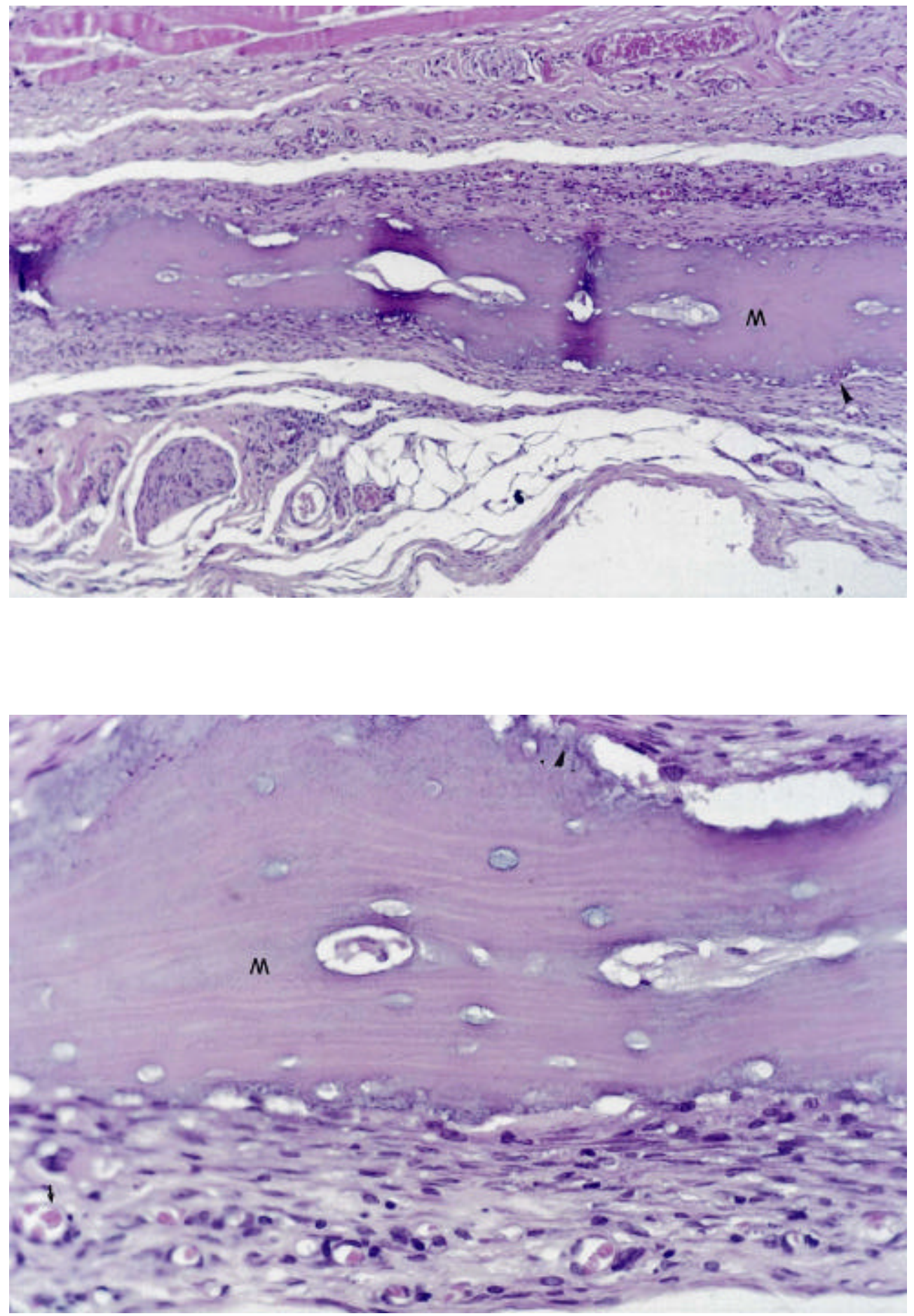

Figura 11. Fotomicrografia do período de 15 dias. Neste período a membrana (M em A) apresentava-se com sinais de invasão e degradação ( ), presença de inúmeros vasos congestos $(\rightarrow)$. Em maior aumento $(B)$ é possível distinguir pequenos vasos $(\rightarrow)$ bem próximos à margem da membrana (M). Aumento: A 10X; B 40X. Coloração hematoxilinaeosina. 

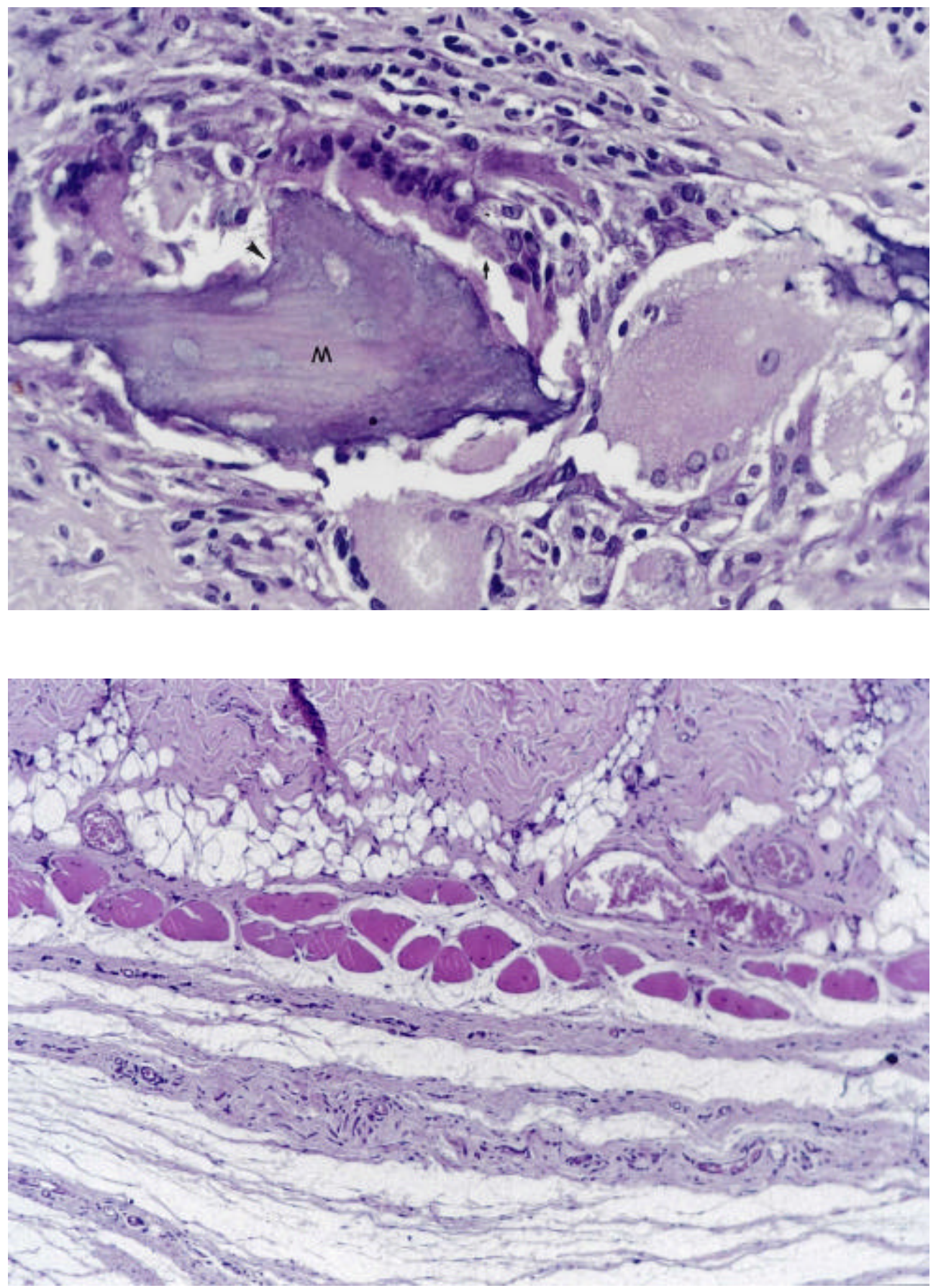

Figura 12. Fotomicrografia do período de 60 e 30 dias. Neste período (60 dias) fragmentos da membrana (M em A)podiam ser vistos, além de sinais de degradação da membrana ( ) e presença de células gigantes multinucleadas $(\rightarrow)$, correspondente ao único animal do período de 60 dias que apresentava fragmentos da membrana. Em outro período (30 dias em B) é possível verificar a presença de tecidos normais. Aumento: A 40X; B 10X. Coloração hematoxilina-eosina. 


\subsection{Estudo comparativo do efeito da adsorção de tetraciclina na degradação da membrana de osso cortical bovino desmineralizado}

$\mathrm{Na}$ análise microscópica após um e três dias da implantação das membranas, tratada ou não com tetraciclina, os eventos celulares observados foram semelhantes nos dois grupos com ambas as membranas intactas (Figura 4). $\mathrm{O}$ infiltrado inflamatório era predominantemente composto por PMNs no primeiro dia. No terceiro dia aparece maior número de células mononucleadas (Figura 9B).

As membranas se encontravam íntegras após sete dias em todas amostras, exceto em um animal no grupo da membrana tratada com tetraciclina, que se encontrava parcialmente degradada. O infiltrado inflamatório era crônico, principalmente composto por células mononucleadas (Figuras 5 e 10).

O processo de degradação das membranas se intensifica no período de 15 dias, quando se observam sinais nítidos de destruição na maioria dos casos (Figuras 6 e 11). Nesta etapa o processo inflamatório passa a apresentar o predomínio de células mononucleadas tipo macrofágicas e células gigantes em contato com os materiais, e a degradação se intensifica ainda mais aos 30 dias quando a maioria dos animais não mais apresenta a membrana. As poucas observadas exibem intensa degradação (Figuras 7 e 12).

Após 60 dias da implantação resquícios do material foram encontrados em três animais do grupo M e em apenas uma no grupo MT. Nestas membranas, macrófagos e células gigantes ainda eram observadas ao redor dos fragmentos. Nos tecidos onde as membranas foram completamente degradadas, o aspecto microscópico era de normalidade (Figuras 8A e 12B).

A fim de comparar a evolução temporal da resposta celular aos dois materiais testados neste trabalho realizamos a análise semiquantitativa das lâminas, atribuindo escores de 0 a 3 (ausente, leve, modera e intenso) para o grau de infiltrado inflamatório, para a presença de PMNs, células gigantes multinucleadas, grau de fibrosamento e angiogênese.

O principal "personagem" da resposta celular frente aos implantes de biomateriais é o infiltrado inflamatório. A avaliação de sua composição e intensidade pode nos fornecer dados importantes quanto a biocompatibilidade do material testado.

Neste trabalho notamos, nos dois grupos experimentais, um infiltrado inflamatório moderado nos períodos de 1, 3 e 7 dias, diminuindo para leve aos 15 dias e praticamente 
ausente após 30 dias (Figura 13). A intensidade do infiltrado inflamatório foi bastante semelhante entre os grupos experimentais.

Corroborando a descrição acima, a presença de PMNs, que predominou no primeiro dia, e a reação inflamatória crônica se manteve leve a moderada nos períodos de 3 a 7 dias em ambos os grupos, mas foi leve aos 15 dias e ausente nos períodos de 30 a 60 dias (Figura 14). Não houve diferença significante dentre as membranas.

As células gigantes (Figura 15) foram notadas a partir de 7 dias (leve), sendo máxima no período de 15 dias em ambos os grupos. No período de 30 dias essas células foram evidentes no grupo M.

A evolução da angiogênese pode ser bem evidenciada na Figura 16, onde notamos a presença de pequenos vasos e capilares próximos às membranas implantadas, cuja progressão temporal vai de leve, no período de 1-3 dias, para intensa aos 7 dias. Com a absorção das membranas e remodelação do tecido, há diminuição da proliferação de vasos até ausência deste fenômeno a partir dos 30 dias, caracterizando assim, o amadurecimento do tecido de granulação.

A análise do grau de fibrosamento (Figura 17) mostrara um aumento de sua intensidade já a partir dos períodos iniciais atingindo o máximo, moderado, aos 15 dias. Este parâmetro permite verificar claramente a remodelação tecidual a partir de 30 dias com a diminuição do fibrosamento (ausente no grupo MT). 


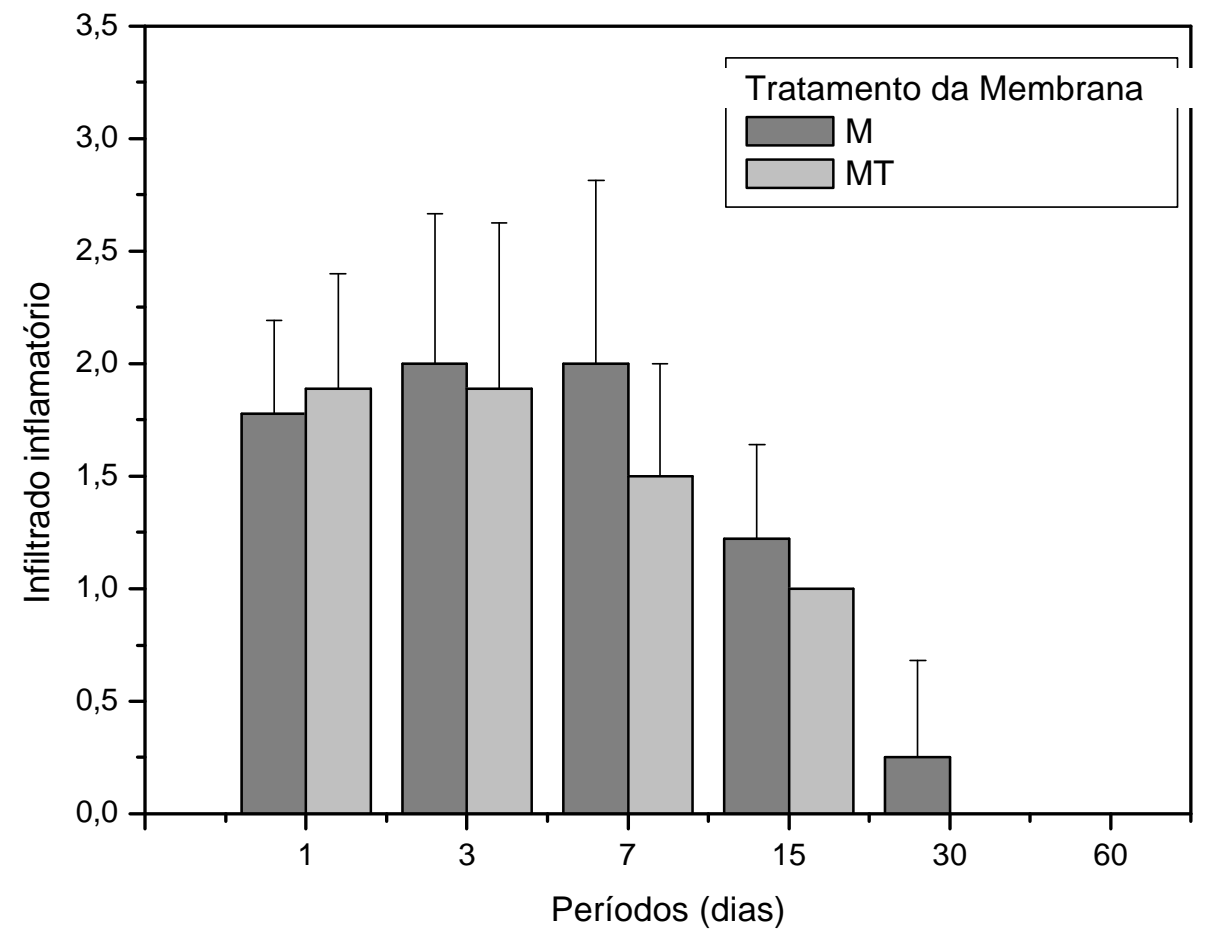

Figura 13. Análise semiquantitativa da intensidade da inflamação nos dois grupos experimentais em função dos períodos experimentais. 


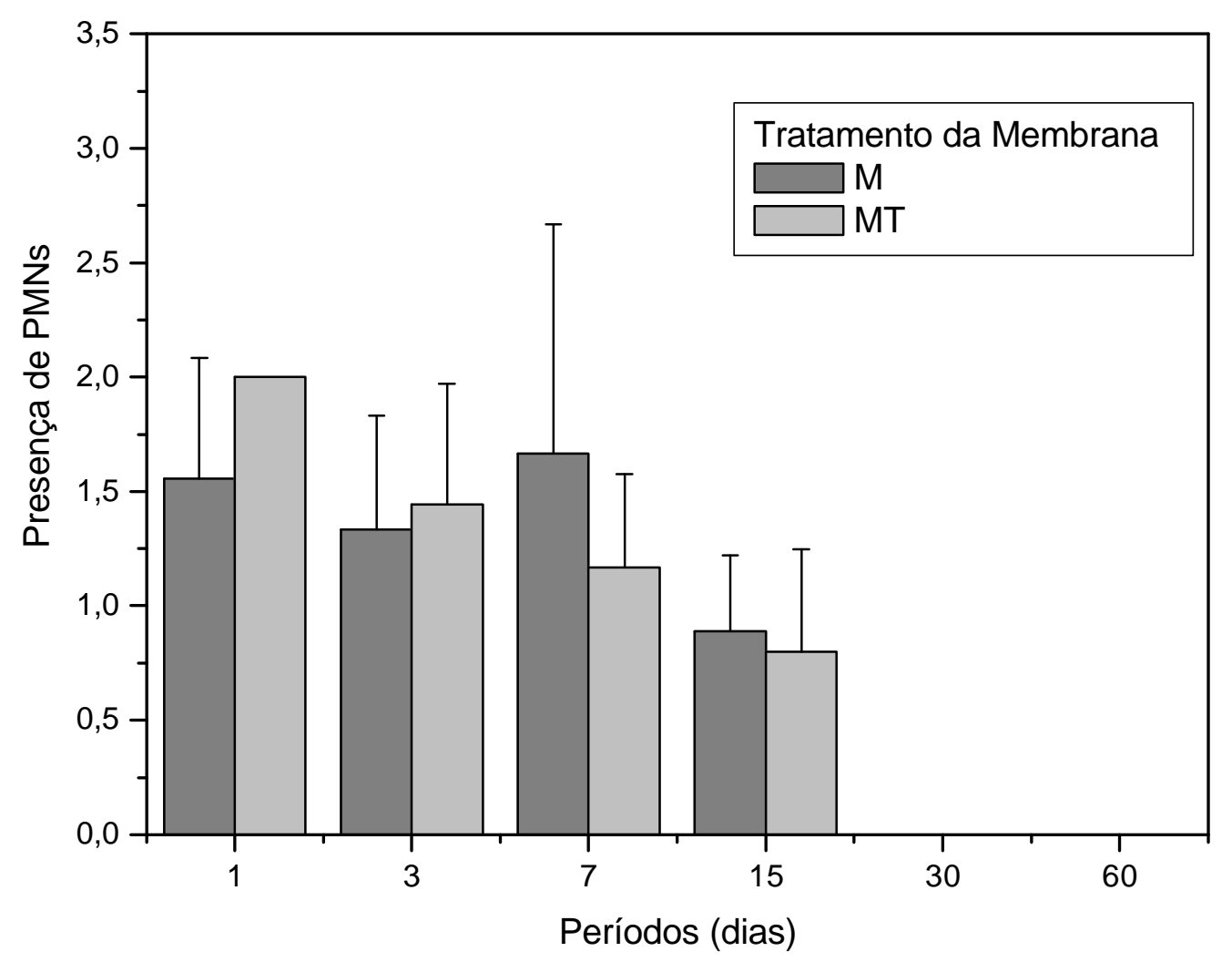

Figura 14. Análise semiquantitativa da presença de polimorfonucleares nos dois grupos experimentais em função dos períodos experimentais. 


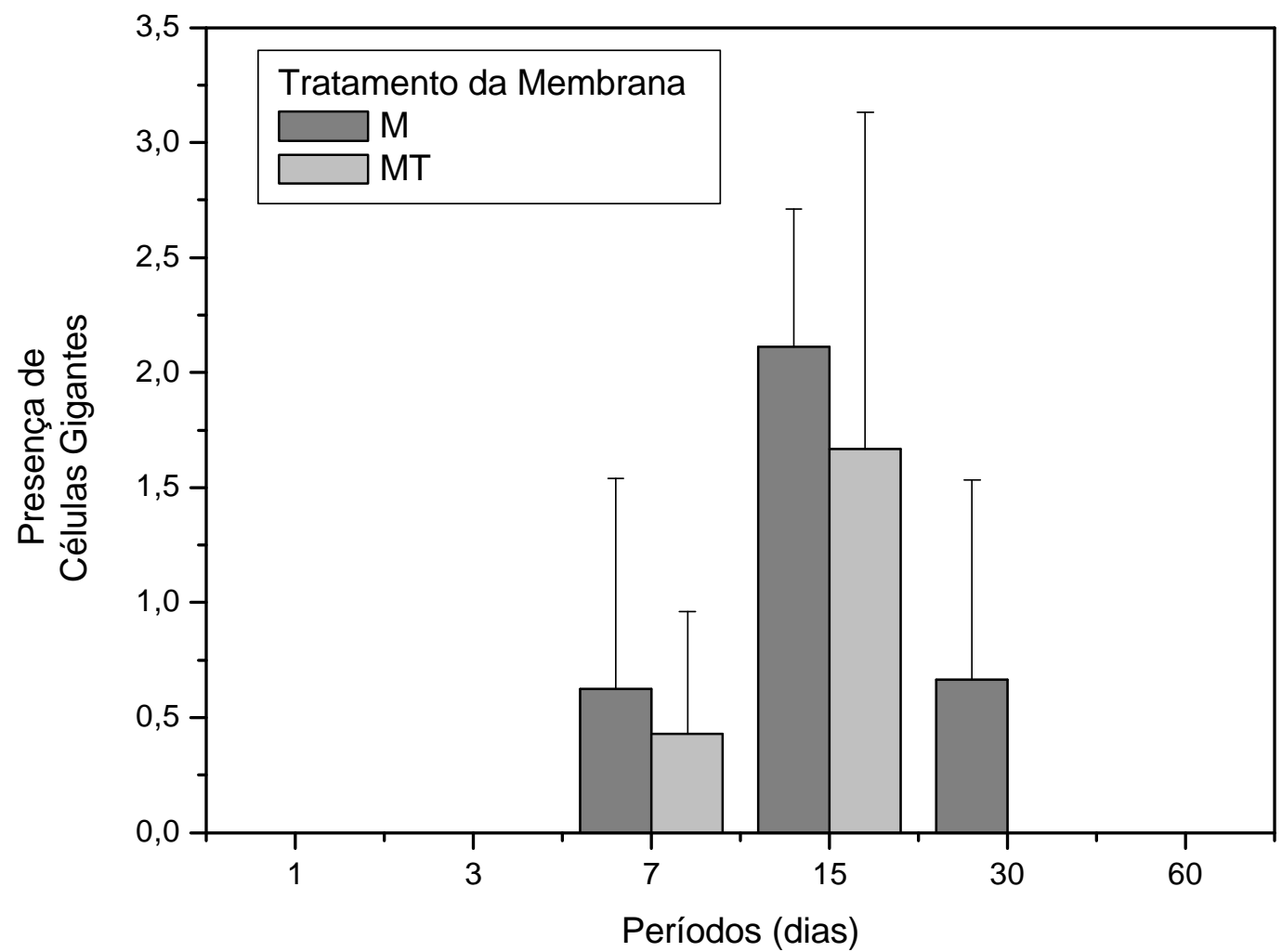

Figura 15. Análise semiquantitativa da presença de Células Gigantes nos dois grupos experimentais em função dos períodos experimentais. 


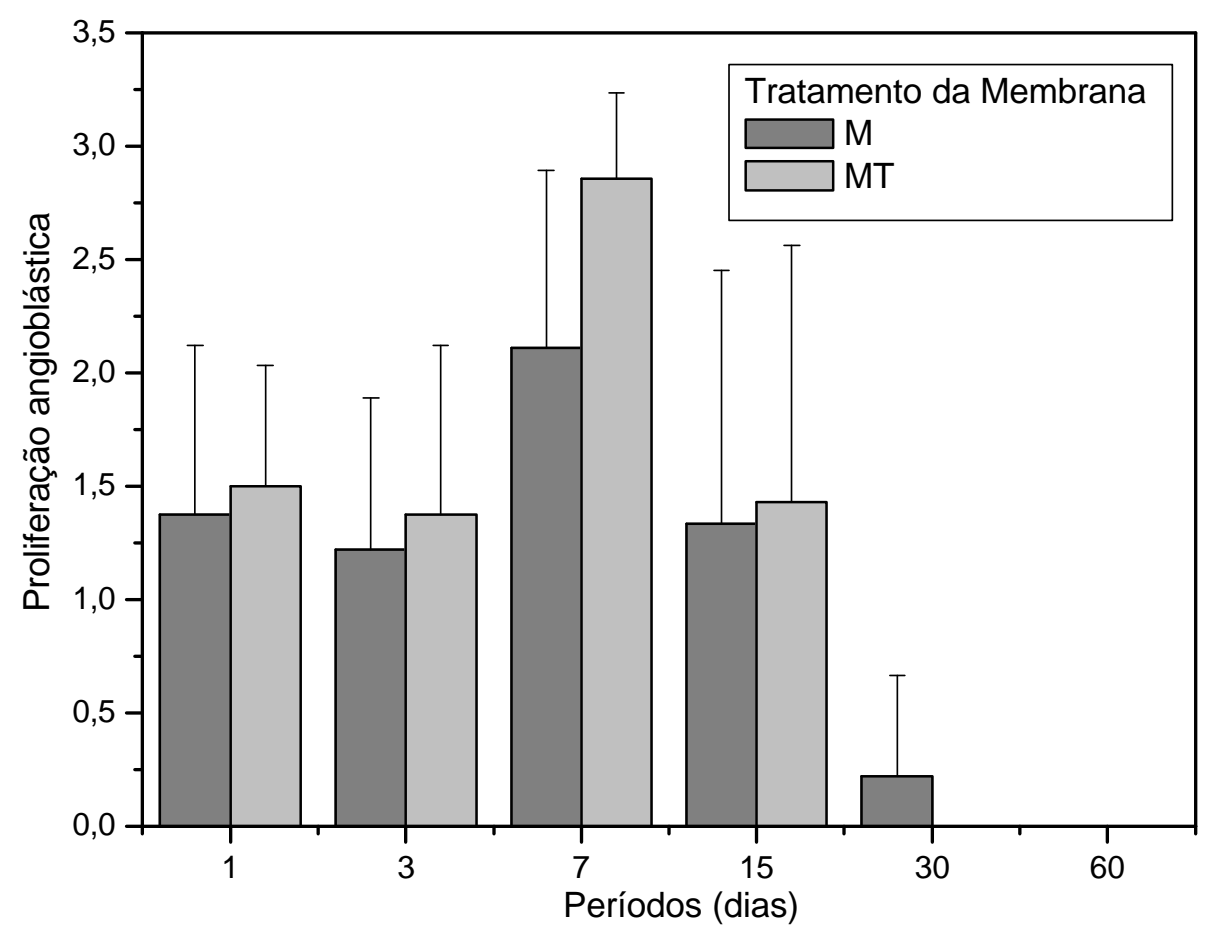

Figura 16. Análise semiquantitativa da proliferação angioblástica no tecido de granulação, nos dois grupos experimentais em função dos períodos experimentais. 


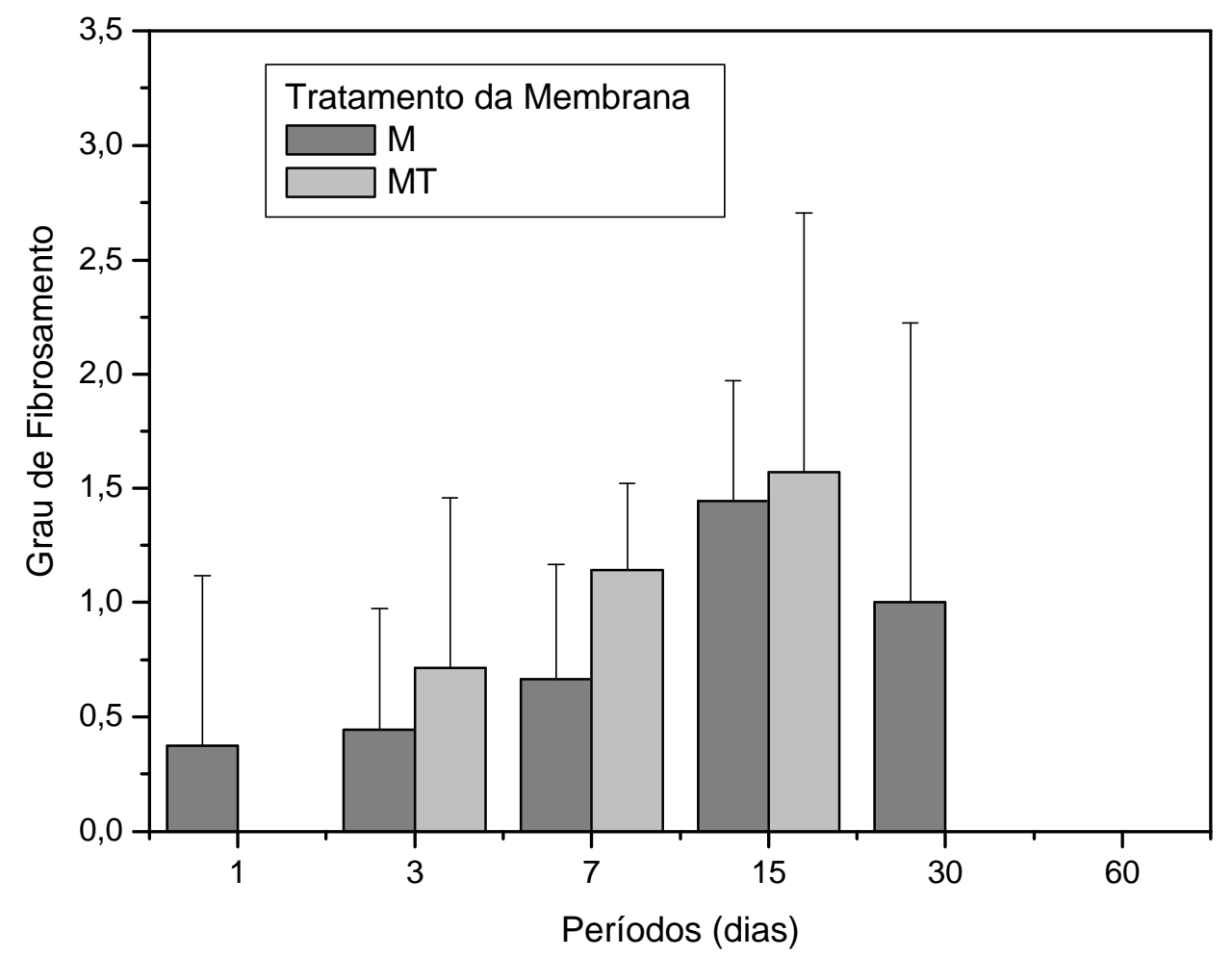

Figura 17. Análise semiquantitativa do grau de fibrosamento nos dois grupos experimentais em função dos períodos experimentais. 


\subsection{Determinação do perfil de fosfatases e enzimas lisossomais durante a bioabsorção da membrana de osso cortical bovino desmineralizado}

A quantificação da atividade específica das varias enzimas nos mostrou dados interessantes. Um dos pontos em comum que percebemos foi a diferença entre a atividade específica, de todas enzimas analisadas, entre a membrana sem tratamento para a membrana com tetraciclina, nos períodos iniciais (1 e 3 dias). Na maioria das enzimas analisadas essa diferença entre os grupos experimentais se estendeu até o período de 7 dias (FAT, FAL, FART, PTPs e Falc).

A atividade específica da FAT foi diferente para os dois grupos experimentais ( $\mathrm{M} \mathrm{e}$ MT) em todos períodos, exceto com 60 dias (Figura 18). De modo geral a atividade da FAT nos dois grupos teve um aumento com o decorrer do tempo, ocorrendo atividade máxima no período de 7 dias no grupo M (28 nmol/min $\mathrm{mg})$ e 14 dias para o grupo MT (24 ng/min mg). A atividade da FAT nos períodos de 1, 3 e 15 dias foi maior no grupo MT, enquanto nos períodos de 7 e 30 dias a atividade registrada foi maior para o grupo $\mathrm{M}$.

A atividade da fosfatase ácida lisossomal (Figura 19) correspondeu, em média, a cerca de 30-40\% da FAT, apresentando um evolução temporal similar à da FAT. Picos de atividade aos 7 (M, 7,5 nmol/ min $\mathrm{mg}$ ) e 14 dias (MT, 8,5 nmol/min $\mathrm{mg}$ ), decrescendo em seguida e não apresentando diferença entre os grupos experimentais.

Pode-se observar que a atividade específica da FART foi extremamente baixa, sendo menor que $10 \%$ em relação à FAT. A atividade máxima observada ocorreu aos 7 dias pósimplantação para os grupos M e MT, com uma AE de 1,1 e 1,4 nmol/ min mg, respectivamente. Em ambos os grupos a atividade enzimática após 60 dias foi similar ao observado no período inicial (Figura 20).

Dentre as diferentes isoenzimas da fosfatase ácida analisada, o perfil PTP de BMr foi muito semelhante ao da FAT (Figura 21), inclusive apresentando os maiores valores de atividade específica. A diferença entre as AE dos grupos experimentais M e MT perdurou até o período de 28 dias. A AE máxima para o grupo $\mathrm{M}$ ocorreu aos 7 dias (20 nmol/min mg) e para o MT aos 14 dias $(16,5 \mathrm{nmol} / \mathrm{min} \mathrm{mg})$.

Bastante interessante foi o perfil exibido pela fosfatase alcalina, cujo pico de atividade máxima ocorreu com 3 dias (M, $19 \mathrm{nmol} / \mathrm{min} \mathrm{mg}$ ) e 1 dia (MT, $8 \mathrm{nmol} / \mathrm{min} \mathrm{mg}$ ), diminuindo progressivamente e sem diferença significativa após 14 dias, atingindo uma atividade residual 
por volta de 1,5 nmol/min mg (Figura 22). A atividade relativamente baixa da Falc após 30 dias, quando praticamente não se encontra mais a membrana no tecido, indica uma forte modulação desta enzima. Um perfil semelhante foi observado para a Arilsulfatase cujos picos de atividade ocorreram nos períodos iniciais, entre 1 e 3 dias para M e MT. Após 30 dias a atividade não apresentou diferença em função do período ou tratamento da membrana (Figura 23).

Os grupos experimentais apresentaram diferenças nos valores referentes a atividade específica da $\beta$-hexosaminidase nos períodos de 1, 3 e 14 dias, sendo maiores no grupo MT, com pico em 3 dias. Esta enzima lisossomal mostrou um comportamento muito semelhante à arilsulfatase após 28 dias de implantação, onde diferenças não foram observadas entre os grupo e períodos experimentais (Figura 24). 


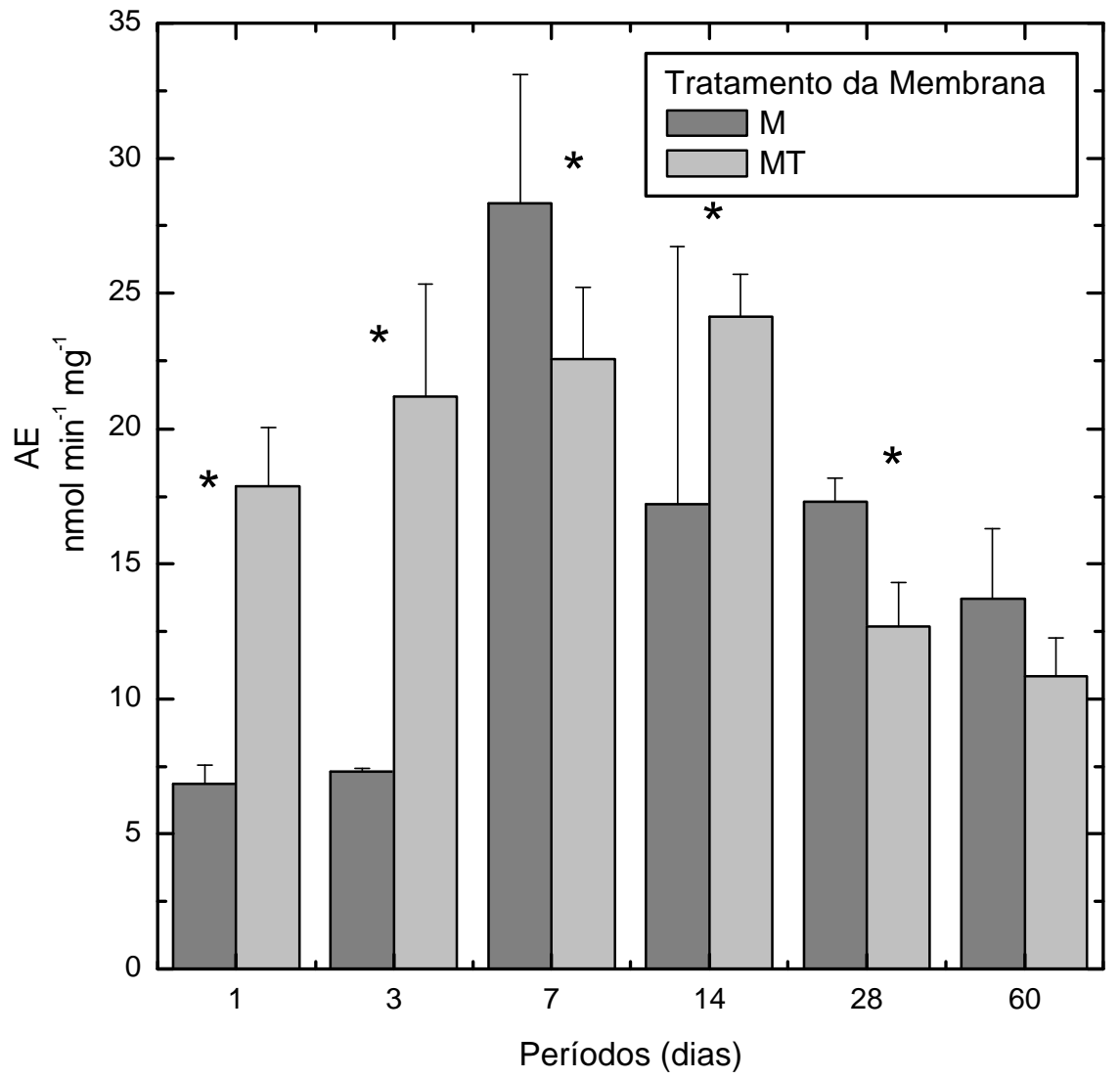

Figura 18. Gráfico representando os valores da atividade específica (AE) da enzima fosfatase ácida total (FAT) para os dois grupos nos diferentes períodos experimentais. Diferença entre os grupos tratados e não tratados em cada período $(* \mathrm{p}<0,05)$. 


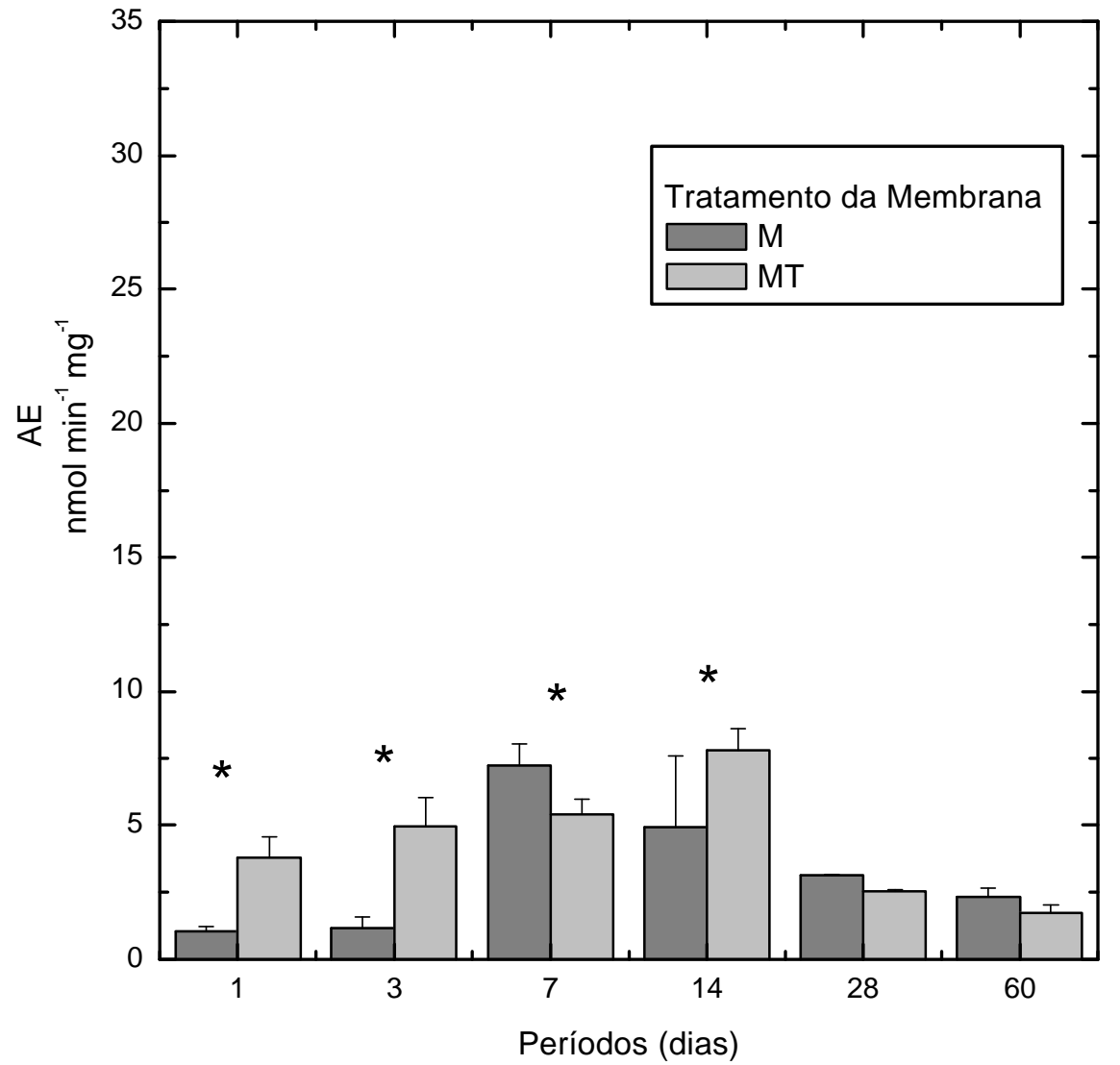

Figura 19. Gráfico representando os valores da atividade específica (AE) da enzima fosfatase ácida lisossomal (FAL) para os dois grupos nos diferentes períodos experimentais. Diferença entre os grupos tratados e não tratados em cada período $\left.*^{*} \mathrm{p}<0,05\right)$. 


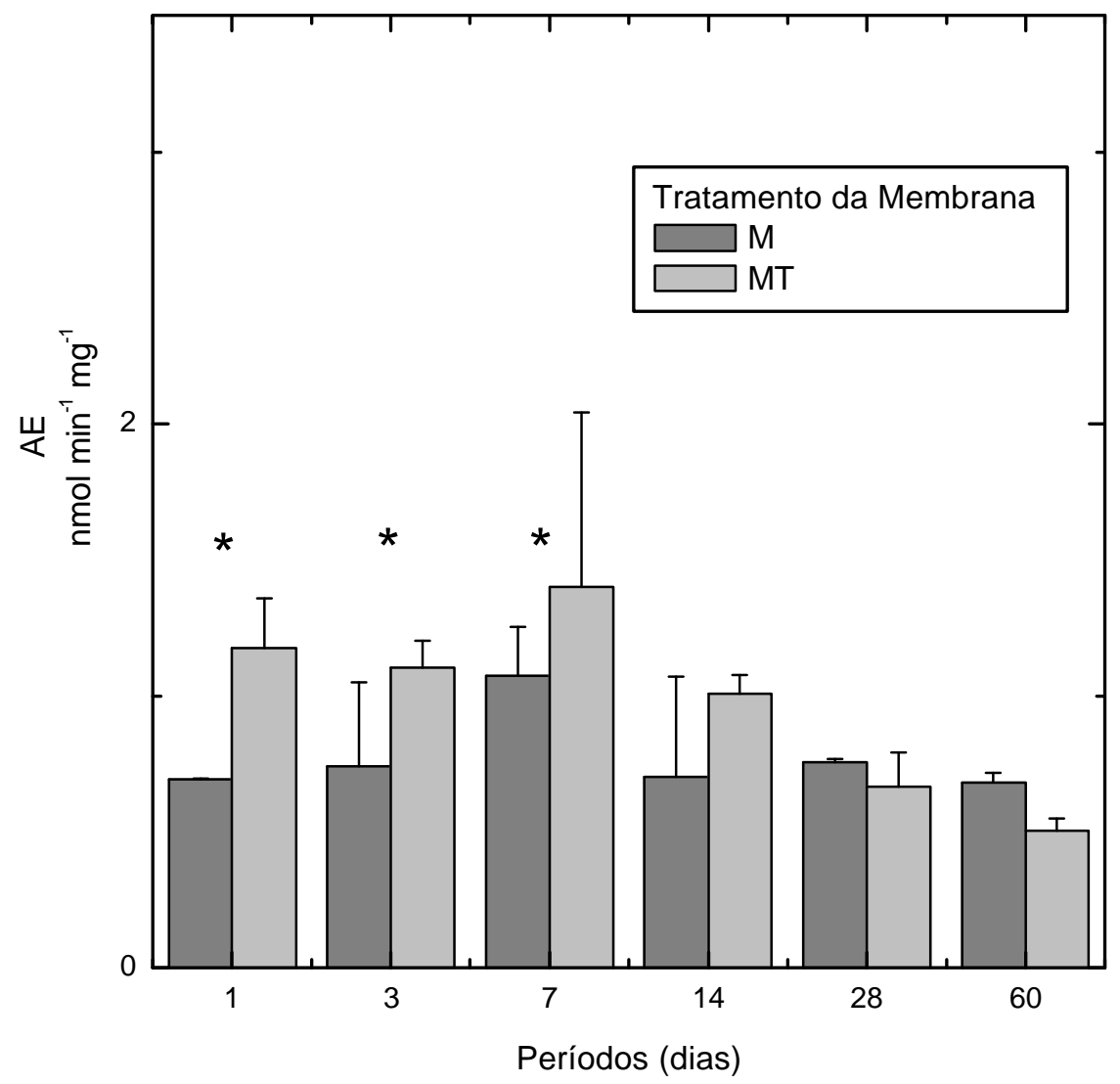

Figura 20. Gráfico representando os valores da atividade específica (AE) da enzima fosfatase ácida tartarato resistente (FART) para os dois grupos nos diferentes períodos experimentais. Diferença entre os grupos tratados e não tratados em cada período $(* p<0,05)$. 


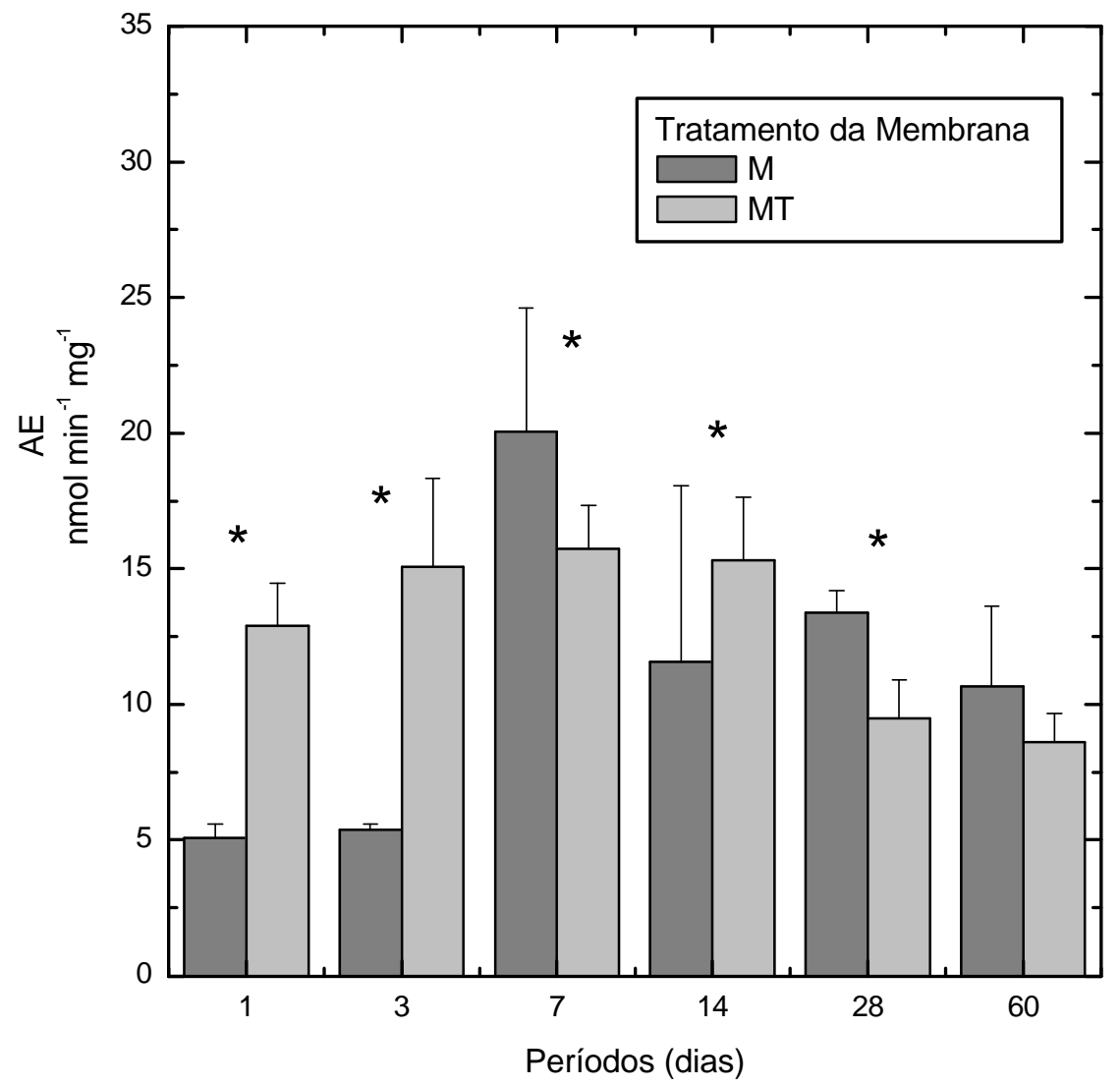

Figura 21. Gráfico representando os valores da atividade específica (AE) da enzima fosfatase ácida de baixa massa molecular relativa (PTP`s) para os dois grupos nos diferentes períodos experimentais. Diferença entre os grupos tratados e não tratados em cada período(* $\mathrm{p}<0,05)$. 


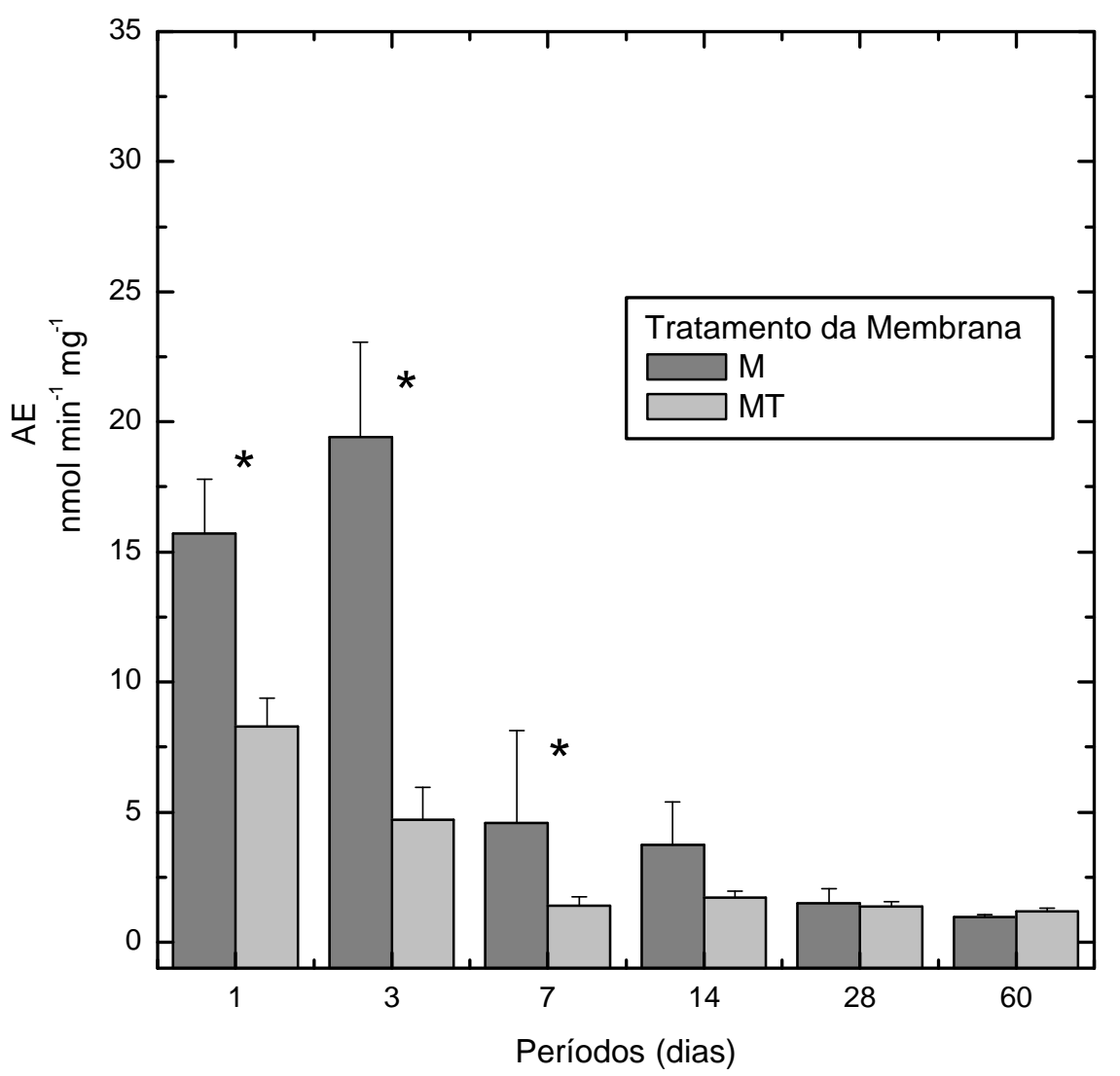

Figura 22. Gráfico representando os valores da atividade específica (AE) da enzima fosfatase alcalina (Falc) para os dois grupos nos diferentes períodos experimentais. Diferença entre os grupos tratados e não tratados em cada período $\left(^{*} \mathrm{p}<0,01\right)$. 


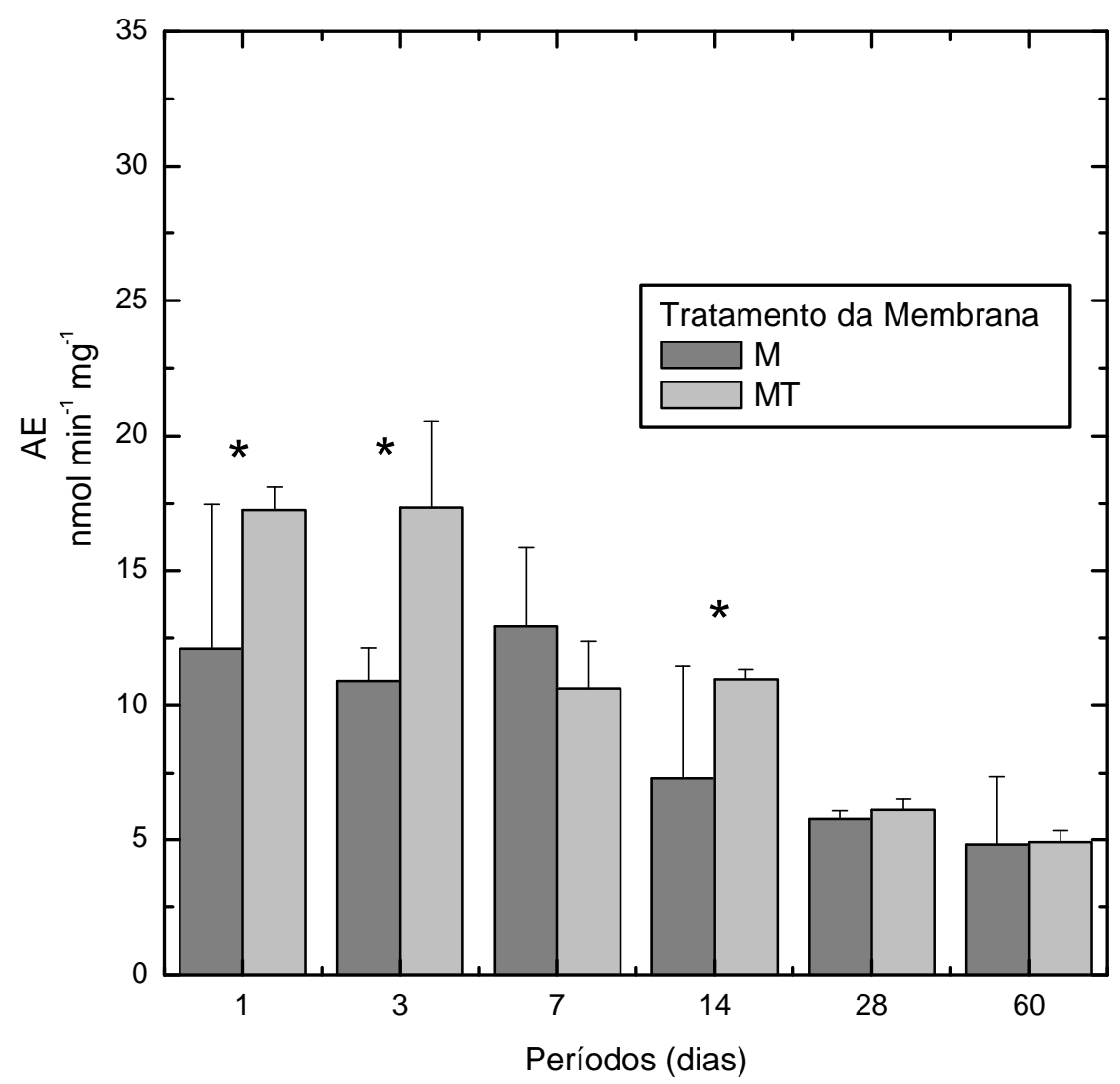

Figura 23. Gráfico representando os valores da atividade específica (AE) da enzima arilsulfatase (ARIL) para os dois grupos nos diferentes períodos experimentais. Diferença entre os grupos tratados e não tratados em cada período $(* \mathrm{p}<0,05)$. 


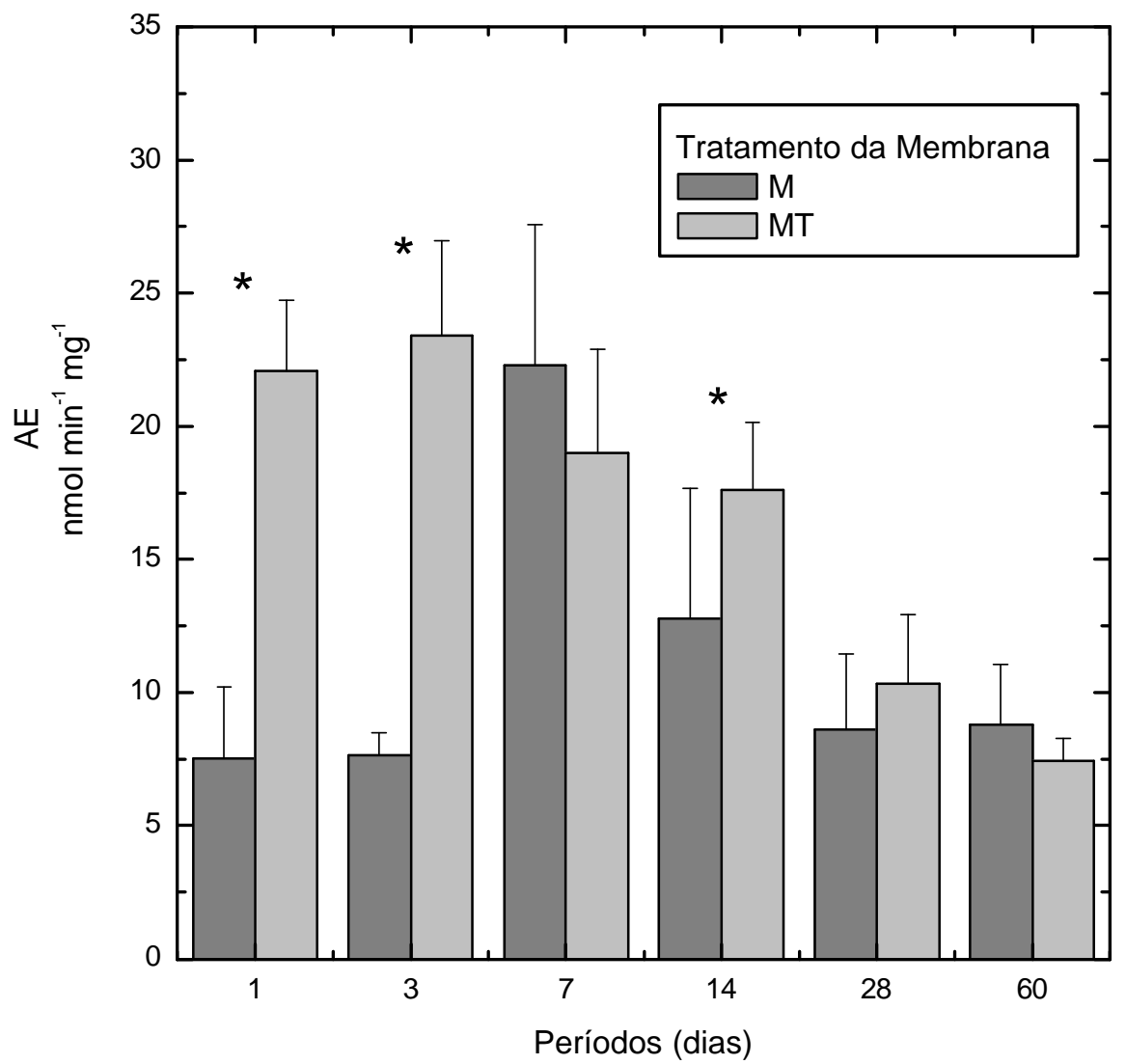

Figura 24. Gráfico representando os valores da atividade específica (AE) da enzima $\beta$ hexosaminidase ( $\beta$-hexo) para os dois grupos nos diferentes períodos experimentais. Diferença entre os grupos tratados e não tratados em cada período $(* \mathrm{p}<0,05)$. 


\section{DISCUSSÃO}

A partir dos estudos de NYMAN et al. (1982) ${ }^{90}$ sobre a eficiência da chamada regeneração tecidual guiada na recuperação dos tecidos periodontais observamos uma constante busca pelo aperfeiçoamento dessa técnica com a utilização de vários tipos membranas ou barreiras biológicas (WARRER et al., 1992; BLUMENTHAL, 1993; BLACK et al., 1994; RACHLIN et al.; 1996; SCHLEGEL et al., 1997; WANG \& MCNEIL, 1998) ${ }^{142,}$ 16, 108, 120, 139 . Ultimamente, dentre os materiais usados para a fabricação dessas barreiras, têmse dado preferência aos materiais absorvíveis para evitar uma segunda etapa cirúrgica. Assim, membranas a base de colágeno, teve já a sua qualidade de aplicação clínica comprovada tanto em RTG como ROG (NEEDLEMAN et al., 2002; OH et al., 2003; DIETRICH et al., 2003) ${ }^{88,}$ 92, 37 , contudo, as bases celulares e moleculares da sua degradação ainda não foram completamente desvendadas (GALGUT et al., 1991) ${ }^{51}$.

Um importante desafio para o uso de barreiras biológicas na periodontia é a possibilidade de sua exposição ao meio bucal, facilitando a colonização por bactérias prejudicando a regeneração adequada dos tecidos periodontais, podendo ainda acelerar o processo de sua degradação, particularmente das membranas de colágeno (WAKABAYASHI et al., 1996; CHEN et al., 1997; SBORDONE et al., 1999; LING et al.; 2003) $)^{138,26,119,83}$. Como a tetraciclina tem sido muito difundida em procedimentos periodontais devido à necessidade de descontaminação da área e o auxílio na regeneração dos tecidos periodontais perdidos (ALGER et al., 1990; DRURY \& YUKNA, 1991; ROSENBERG \& ROSE, 1998; DELAISSE et al., 2000; HOUSER et al., 2001) 2, 41, 112, 36, 63 , parece bastante lógico utilizá-la adsorvida às membranas absorvíveis. A sua liberação lenta e gradual auxiliaria na descontaminação da área tratada e também impediria a possível colonização bacteriana da membrana, auxiliando na regeneração tecidual.

Deste modo, no atual estudo procuramos testar esse tipo de membrana em comparação com a não impregnada com antibiótico em tecido subcutâneo de ratos. Salientamos que como relatos na literatura sobre teste de membranas em subcutâneo são escassos, é de grande importância inicialmente entendermos os fenômenos que regem a resposta tecidual e a absorção desse tipo de membrana para melhor orientar a sua aplicação futura na clínica odontológica. 
Os resultados encontrados nesse estudo, mostraram que a membrana de cortical óssea bovina desmineralizada foi completamente reabsorvida após 30 dias, sendo mais rapidamente nas contendo tetraciclina. Membranas de colágeno tipo I fibrilar testadas por outros pesquisadores (PITARU et al., 1989; BOON et al., 1995) ${ }^{106,17}$ geralmente não permanecem por mais de 30 a 45 dias, sendo completamente reabsorvidas, sem indução de calcificação. Trabalhos utilizando membranas originarias de osso humano demonstraram resultados clínicos satisfatórios quando comparados com a membrana de PTFEe em técnicas de regeneração tecidual guiada, no entanto a fonte de obtenção desse tipo de material é bem limitada e os mecanismos de sua ação ainda não foram bem esclarecidos ${ }^{145,85,121,49,70}$.

O processo de degradação de membrana de cortical óssea bovina envolveu o recrutamento de PMNs na fase inicial de inflamação aguda. Lembramos que essa fase também está relacionada ao trauma cirúrgico e que os achados histológicos correlacionaramse positivamente com a maior atividade das enzimas lisossomais, FAL, arilsulfatase e Bhexosaminidase. À medida que o processo inflamatório passou a ter um predomínio de macrófagos e células gigantes, com a respectiva diminuição no número de PMNS, a degradação das membranas acentuou- se, em particular a partir do período de 15 dias, quando, ainda, a atividade lisossomal manteve-se em níveis similares aos períodos iniciais.

A atividade da PTP foi marcante em todos os períodos experimentais. A despeito de sua função biológica estar inversamente associada ao controle do ciclo celular, pouco se sabe sobre a sua modulação durante eventos fisiopatológicos (OLIVEIRA et al., 1999; SICCA et al. 2000 $)^{94,125}$. Pelos resultados, ficou evidente, o envolvimento desta classe de enzimas no processo de degradação e remodelação do tecido, mas seu exato papel deverá ser objeto de futuros estudos.

Embora nas análises microscópicas descritiva e semiquantitativa não tenham sido observadas diferenças importantes na resposta às duas membranas, a análise enzimática mostrou claramente que a adsorção de tetraciclina induziu a uma atividade significativamente maior da FAL, arilsulfatase e ß-hexosaminidase. Associando esta informação ao fato de que a membrana tratada com tetraciclina desapareceu mais rapidamente do tecido, podemos inferir que a ação destas enzimas possa ter sido preponderante para a sua absorção mais rápida.

A despeito dos relatos de BETTANY et al. $(2000)^{13}$ descrevendo o poder de regulação e inibição que a tetraciclina exerce sobre as metaloproteinases de matriz (algumas responsáveis pela degradação do colágeno), nossos resultados mostraram que, ao contrário, a 
adsorção da tetraciclina acelerou a degradação da membrana em relação à àquela sem tetraciclina. GREENWALD et al. (1998) ${ }^{54}$ demonstraram in vitro que a tetraciclina inibia a produção de colagenase (principal enzima envolvida na degradação do colágeno), mas que esse efeito era dose-dependente, enfatizando a necessidade de uma dose mínima para que houvesse o efeito. Assim, no nosso caso a concentração de tetraciclina biologicamente disponível após a implantação da membrana, poderia ter sido inferior à necessária para inibir as colagenases do hospedeiro. Uma outra possibilidade é que a degradação inicial causada pelas enzimas lisossomais tenha favorecido a ação de outras enzimas proteolíticas uma vez que é notória a superposição de atividade dentre as diferentes proteases.

Durante todo o processo de reabsorção da membrana não foi notada a presença de cápsula fibrosa envolvendo o material. A células inflamatórias recrutadas para a resposta tecidual, bem como a angiogênese, apresentavam-se envolvendo o material, e eventualmente, através de frestas ou poros, penetravam no interior da membrana. Nenhum sinal de necrose tecidual foi observado em qualquer período experimental. Este é um aspecto importante, uma vez que, um requisito fundamental para a RTG ou ROG é a ausência de resposta inflamatória exagerada frente ao material, que possa impedir o reparo da área implantada (JANSEN et al., $1995)^{68}$. Da mesma forma, a resposta imune é indesejada e, neste trabalho, pudemos verificar que o sistema imune não foi acionado em resposta ao material (LINDE et al., 1993) ${ }^{82}$.

Atualmente existem no mercado nacional membranas degradáveis como Vycril (poligalactina), Resolut (polímero de ácido lático e ácido glicólico) e Bio-Guide (bicamada de peritônio de porcos). ZHAO et al. (2000) ${ }^{147}$ examinaram a resposta celular a estes materiais em comparação à membrana de PTFE-e (controle) implantados no tecido subcutâneo de ratos. Verificaram que somente o controle foi bem tolerado e encapsulado por tecido fibroso. Por outro lado, Vycril, Resolut e Bio-Guide induziram um significativo edema, encapsulamento e extensa área inflamatória. O Vycril manteve-se estável, mas induziu a um aumento crescente de células gigantes, enquanto Resolut e Bio-Guide proporcionaram uma reação tipo corpoestranho clássica, que se manteve até o último período estudado (21 dias).

Os resultados apresentados por ZHAO et al. (2000) ${ }^{147}$ são completamente distintos dos relatados neste trabalho, pois as células gigantes observadas no período de 15 a 30 dias mantiveram-se apenas pela presença das membranas, desaparecendo com o reparo tecidual. $\mathrm{O}$ envolvimento de células gigantes na absorção de colágeno sem ligação cruzada tem sido 
relatado em diversos artigos (GALGUT et al., 1991; BOON et al., 1995) ${ }^{51,17}$, as quais aparecerem após a fase inicial aguda do processo, com a participação de PMNs e linfócitos. Com o decorrer do tempo o tecido reacional passa a ser composto predominante por células gigantes e macrófagos, que desaparecem após a degradação do colágeno (BOON et al., $1995)^{71}$.

Estudos realizados anteriormente com a mesma membrana avaliada neste trabalho, sem tetraciclina e colocada sobre defeitos ósseos, revelou que sua absorção ocorreu sem qualquer prejuízo ao tecido hospedeiro, ausência de exsudato purulento ou áreas de necrose (TAGA et al., 1997; BENOIT NÚÑEZ, 1999) ${ }^{130,10}$. No relato de TAGA et al. (1997) ${ }^{130}$ a membrana foi lentamente absorvida através de processo mediado por células mononucleadas, semelhantes a fibroblastos.

Os estudos em modelos animais, usando implante de biomateriais em subcutâneo, têm mostrado duas respostas distintas. Assim, a implantação subcutânea ou intramuscular de matriz óssea desvitalizada e desmineralizada pode induzir a osteogênese em um sítio ectópico (URIST e STRATES, 1970; REDDI E HUGGINS, 1972) ${ }^{133,109}$. A osteoindução pode ser acompanhada tanto in vitro como in vivo pelo aumento da atividade da fosfatase alcalina ao redor do período de 14 a 21 dias. Como a membrana utilizada neste trabalho foi obtida a partir do osso cortical bovino desmineralizado através de protocolo semelhante ao descrito por URIST et al. (1965) ${ }^{132}$, o potencial osteoindutor do material não poderia ser descartado. Contudo, a análise microscópica excluiu a presença de áreas com osteogênese e as dosagens de fosfatase alcalina não evidenciaram atividade compatível com processo de osteogênese durante a fase de absorção da membrana.

Por outro lado, a implantação de matriz óssea desvitalizada e mineralizada no tecido subcutâneo ou intramuscular inibe esta capacidade indutiva (URIST \& STRATES, 1970) ${ }^{133}$. REDDI \& HUGGINS (1972) ${ }^{109}$ identificaram células gigantes multinucleadas, ricas em ácidos orgânicos presumivelmente para dissolução mineral, no sítio de implantação de matriz mineralizada. Eles propuseram que a presença de matriz mineralizada sozinha ou em combinação com matriz desmineralizada, inibia a osteogênese.

A natureza das células gigantes multinucleadas inflamatórias (CGMIs) recrutadas nos enxertos subcutâneos de partículas mineralizadas ainda é motivo de controvérsia na literatura. Porém, foi relatado que a implantação de partículas de hidroxiapatita natural desproteinizada termicamente induzia a uma reação inflamatória crônica com presença de células gigantes e 
fibrosamento ao redor das partículas no subcutâneo de ratos (OLIVEIRA et al., 1999; SICCA et al., 2000) $)^{94, .125}$.

Em vista dos resultados obtidos no atual estudo, é plausível sugerir que se durante o processo de desmineralização do osso bovino para a obtenção das membranas tenha ocorrido a permanência de resquícios da fase mineral em sua estrutura, assim o recrutamento de células gigantes seria um evento esperado.

Esse tipo de resposta não implica necessariamente na desqualificação do material com base no relato de KELLY \& SCHNEIDER (1991) ${ }^{71}$ que implantaram matriz alogênica desmineralizada, mineralizada e a combinação de ambas, na região subcutânea dorsal de ratos adultos jovens e verificaram nos implantes mineralizados a presença de células gigantes multinucleadas que não possuíam morfologia caracteristicas de osteoclastos. No implante de matriz desmineralizada, a maioria das células gigantes demonstrou uma morfologia similar a osteoclastos, enquanto que a implantação combinada dos materiais proporcionou a presença desses dois tipos de células gigantes multinucleadas. A fosfatase ácida resistente ao tartarato (TRAP) é classicamente um marcador de osteoclastos (ODDIE et al., 2000) ${ }^{91}$. Foi possível observar neste estudo que a atividade TRAP foi extremamente baixa e discreta em relação às outras fosfatase. $\mathrm{O}$ aspecto microscópico das células gigantes em contato com as membranas implantadas e a tênue atividade TRAP indicaram que as células gigantes multinucleadas encontradas não possuem características de osteoclastos.

A presença de cálcio no material, ativando o recrutamento de células gigantes multinucleadas pode ser um elemento adicional na velocidade de degradação da membrana. Isto sugere a necessidade de estudos mais detalhados no sentido de definir a verdadeira participação do cálcio na resposta celular a esta membrana. 


\section{CONCLUSÃO}

A membrana Gen-derm ${ }^{\circledR}$ é bem tolerada pelos tecidos sendo completamente absorvida no período de 30-60 dias pelo conjunto de células mononucleadas e células gigantes multinucleadas que desaparecem ao final do processo. O tratamento da membrana Genderm ${ }^{\circledR}$ com tetraciclina provoca uma pequena mudança aparente nos achados microscópicos, mas modifica significativamente a atividade específica das enzimas analisadas nos períodos iniciais de implantação em conjuntivo subcutâneo de ratos, em particular das enzimas lisossomais (FAL, ARIL e B-HEXO.

Ambas as membranas testadas apresentam-se como possível opção para pesquisas futuras em técnicas de regeneração tecidual guiada, tanto em termos de biocompatibilidade como tempo de absorção. 


\section{PERSPECTIVAS FUTURAS}

Os resultados com uso de materiais a base de colágeno vem sendo bastante animadores, não só com seu emprego na odontologia (especificamente como barreira), mas também em outras áreas como a ortopedia, dermatologia e oftalmologia. Esse material pelas suas características tão nobres vem sendo empregado na chamada Engenharia de Tecidos.

Como perspectivas futuras, alguns trabalhos deveriam ser desenvolvidos tais como:

- Avaliar a eficiência da Gen-Derm®, sem ou com tetraciclina, na RTG e ROG, utilizando modelos animais e, posteriormente, estudos clínicos;

- Determinar a concentração residual de cálcio na membrana e seu efeito no tempo de absorção;

- Avaliar o potencial da membrana como carreador de fatores de crescimento e células, em particular células do ligamento periodontal.

- Avaliar o efeito de outras tetracilinas sobre o tecido. 


\section{Referências Bibliográficas}

1. AL-ARRAYED, F.; MORAN, A.S.; DOWELL, P. Clinical trial of cross-linked human type I collagen as a barrier material in surgical periodontal treatment. J. Clin. Periodontol., v. 22, n. 5, p. 371-379, 1995.

2. ALGER, F.A.; SOLT, C.W.; VUDDHAKANOK, S.; MILES, K. The histologic evaluation of new attachment in periodontally diseased human roots treated with tetracycline-hydrochloride and fibronectin. J. Periodontol., v. 61, n. 7, p. 447-455, 1990.

3. ALVAREZ-LEAL, M.; AGUIRRE, R.M.; CAREAGA-OLIVARES, J.; ZUNIGACHARLES, M.A.; HERNANDEZ-TELLEZ, A. Arylsulfatase A levels in patients with chronic alcoholism. Arch. Med. Res., v. 31(6), p. 585-588, 2000.

4. ANSELME, K. Osteoblast adhesion on biomaterials. Biomaterials, v. 21, n. 7, p. 667$681,2000$.

5. ARAUJO, P.S.; MIES, V.; MIRANDA, O. Subcellular distribution of low- and highmolecular-weight acid phosphatases. Biochim Biophys Acta., v. 452, n. 1, nov, p. 121-130, 1976.

6. BAKONSKA-PACON, E.; KARMOWSKI, A.; SOBIECH, K.A.; TERPILOWSKI, L.; KASIAK, J.; MALIK, B. Changes in arylsulphatase activity (EC 3.6.1) in the blood serum and urine in women during the pregnancy and in the course of delivery. Ginekol Pol., v. 70, n. 7, p. 490-494, 1999. 
7. BARBOZA, E.P.; DUARTE, M.E.L.; GEOLÁS, L.; SORENSEN, R.G. Ridge augmentation following implantation of recombinant human bone morphogenetic protein-2 in the dog. J. Periodontol., v. 71, p. 488-496, 2000.

8. BASSETTO, A.P.; NEVES, F.T.A.; TOLEDO, S.F.; SILVA, T.L.; BUZALAF, M.A.R.; FARIA, F.A.C.; GRANJEIRO, J.M. Effect of cigarette smoke on sublingual gland and liver phosphotyrosine protein phosphatase and acid phosphatase activities. Rev. FOB, v. 9, n. 1/2, p. 49-54, 2001.

9. BAXTER, J.H. \& SUELTER, C.H. Multiple acid phosphatases in avian pectoral muscle--the postmicrosomal supernatant acid phosphatase is elevated in avian dystrophic muscle. Arch Biochem Biophys., v. 228, n. 2, feb, p. 397-406, 1984.

10. BENOIT NÚÑEZ, J.S. Análise histológica da reabsorção e da biocompatibilidade de membrana de cortical óssea bovina colocada sobre calvária de cobaia decorticada. Bauru, 1999. 100p. Tese (Mestrado), Faculdade de Odontologia de Bauru, Universidade de São Paulo.

11. BENQUE, E.; ZAHEDI, S.; BROCARD, D.; OSCABY, F.; JUSTUMUS, P.; BRUNEL, G. Guided tissue regeneration using a collagen membrane in chronic adult and rapidly progressive periodontitis patients in the treatment of 3-wall intrabony defects. J. Clinical Periodontol., v. 24, n. 8, p. 544-549, 1997.

12. BENQUE, E.; ZAHEDI, S.; BROCARD, D.; MARIN, P.; BRUNEL, G.; ELHARAR, F. Tomodensitometric and histologic evaluation of the combined use of a collagen membrane and a hydroxyapatite spacer for guided bone regeneration: A clinical report. Int. J. Oral maxillofac. Implants, v. 14, n. 2, p. 258-264, 1999. 
13. BETTANY, J.T., PEET, N.M., WOLOWACZ, R.G., SKERRY, T.M., GRABOWSKI, P.S. Tetracycline induce apoptosis in osteoblasts. Bone. v. 27, n. 1, p. 75-80, 2000.

14. BLACK, B.S., GHER, M.E., SANDIFER, J.B., FUCINI, S.E., RICHARDSON, A.C. Comparative study of collagen and expanded polytetrafluoroethylene membranes in the treatment of human class II furcation defects. J. Periodontol., v. 65, n. 6, p. 598-604, 1994.

15. BLUMENTHAL, N.M. The use of collagen membranes to guide regeneration of new connective tissue attachment in dogs. J. Periodontol., v. 59, n. 12, p. 830-836, 1988.

16. BLUMENTHAL, N.M. A clinical comparison of collagen membranes with ePTFE membranes in the treatment of human mandibular buccal class II furcation defects. J. Periodontol, v. 64, n. 10, p. 925-933, 1993.

17. BOON, M.E., RUIJGROK, J.M., VARDAXIS, M.J. Collagen implants remain supple not allowing fibroblast ingrowth. Biomaterials, v. 16, n. 14, p. 1089-1093, 1995.

18. BORD, S.; HORNER, A.; HEMBRY, R.M.; REYNOLDS, J.J.; COMPSTON, E. Production of collagenase by human osteoblasts and osteoclasts in vivo. Bone, v. 19, n. 1, p. 35-40, 1996.

19. BRADFORD, M.M. A rapid and sensitive method for the quantitation of microgram quantities of protein utilizing the principle of protein-dye binding. Anal Biochem., v. 7, n. 72, may, p. 248-254, 1976.

20. BRUNEL, G., BROCARD, D., DUFFORT, J.F., JACQUET, E., JUSTUMUS, P., SIMONET, T., BENQUE, E. Bioabsorbable materials for guided bone regeneration 
prior to implant placement and 7-year follow-up: report of 14 cases. $J$. Periodontol., v. 72, n. 2, p. 257-264, 2001.

21. BULL, H.; CHOY, M.; MANYONDA, I.; BROWN, C.A.; WALDRON, E.E.; HOLMES, S.D.; BOOTH, J.C.; NELSON, P.N. Reactivity and assay restriction profiles of monoclonal and polyclonal antibodies to acid phosphatases: a preliminary study. Immunol Lett., v. 70, n. 3, dec, p. 143-149, 1999.

22. BUNYARATAVEJ P, WANG HL. Collagen membranes: A review. J. Periodontol., v. 72, n. 2, p. 215-229, 2001.

23. BUZALAF, M.A.R., GRANJEIRO, J.M., FERREIRA, C.V., LOURENÇÃO, V.A., ORTEGA, M.M., POLETTO, D.W., TAGA, E.M., AND AOYAMA, H. Kinetic characterization of bovine lung low-molecular-weight protein tyrosine phosphatase. Exper. Lung. Res., v. 24, n. 3, p. 269-272, 1998.

24. CHAIMOVICH, H. \& NOME, F. Purification and properties of an acid phosphatase from bovine brain. Arch Biochem Biophys., v. 139, n. 1, jul, p. 9-16, 1970.

25. CHEN, C.C.; WANG, H.L.; SMITH, F.; GLICKMAN, G.N.; SHYR, Y.; O’NEAL, R.B. Evaluation of a collagen membrane with and without bone grafts in treating periodontal intrabony defects. J. Periodontol., v. 66, n. 10, p. 838-847, 1995.

26. CHEN, C.C.; WANG, H.L.; LOPATIN, D.E.; O’NEAL, R.B.; MacNEIL, R.L. Bacterial adherence to guided tissue regeneration barrier membranes exposed to the oral environment. J Periodontol., v. 68, n. 2, feb, p. 172-179, 1997. 
27. CHIARUGI, P.; CIRRI, P.; RAUGEI, G.; CAMICI, G.; DOLFI, F.; BERTI, A.; RAMPONI, G. PDGF receptor as a specific in vivo target for low $\mathrm{M}(\mathrm{r})$ phosphotyrosine protein phosphatase. FEBS Lett., v. 372, n. 1, sep, p. 49-53, 1995.

28. CHIARUGI, P.; TADDEI, M.L.; CIRRI, P.; TALINI, D.; BURICCHI, F.; CAMICI, G.;MANAO, G.; RAUGEI, G.; RAMPONI, G. Low molecular weight proteintyrosine phosphatase controls the rate and the strength of NIH-3T3 cells adhesion through its phosphorylation on tyrosine 131 or 132. J Biol Chem., v. 275, n. 48, dec, p. 37619- 37627, 2000.

29. CHOI, S.H.; KIM, C.K.; CHO, K.S.; HUH, J.S.; SORENSEN, R.G.; WOZNEY, J.M.; WIKESJO, U.M.E. Effect of recombinant human bone morphogenetic protein2/absorbable collagen sponge (rhBMP-2/ACS) on healing in 3-Wall intrabony defects in dogs. J. Periodontol., v. 73, p. 63-72, 2002.

30. ChristgaU, M.; SCHMAlZ, G.; WENZEL, A.; HILlER, K.-A. Periodontal regeneration of intrabony defects with resorbable and non-resorbable membranes: 30-month results. J. Clin. Periodontol., v. 24, n. 1, p. 17-27, 1997.

31. CHUNG, K.M., SALKIN, L.M., STEIN, M.D., FREEDMAN, A.L. Clinical evaluation of a biodegradable collagen membrane in guided tissue regeneration. $\boldsymbol{J}$. Periodontol., v. 61, n. 12, p. 732-736, 1990.

32. CIANCAGLINI, P.; PIZAURU, J.M.; LEONE, F.A. Polyoxyethylene 9-lauryl ethersolubilized alkaline phosphatase: synergistic stimulation by zinc and magnesium ions. Int J Biochem., v. 24, n. 4, apr, p. 611-615, 1992. 
33. CIRELLI, J.A., MARCANTONIO, J.R., E., MARCANTONIO, R.A.C., LIA, R.C.C., GOISSIS, G. AND ROSSA JR., C. Evaluation of anionic collagen membranes in the treatment of class II furcation lesions: na histometric analysis in dog. Biomaterials, v. 18, n. 18, p. 1227-1234, 1997.

34. COLANGElO, P.; PIATtElli, A. BARRUCCI, S. TRISI, P.; FORMISANO, G.; CAIAZZA, S. Bone regeneration guided by resorbable collagen membranes in rabbits: a pilot study. Implant Dent., v. 2, n. 2, p.101-105, 1993.

35. COLEMAN, R.A.; SCHOFIELD, B.H.; McDONALD, D.F. Selective localization of a Golgi apparatus acid phosphatase isoenzyme in bone using pyridoxal-5'-phosphate. J Histochem Cytochem., v. 28, n. 2, feb, p. 115-123, 1980.

36. DELAISSÉ, J.M.; ENGSIG, M.T.; EVERTS, V.; OVEJERO, M.C.; et al. Proteinases in bone resorption: obvious and less obvious roles. Clinica Chimica Acta., v. 291, p. 223-234, 2000.

37. DIETRICH, T.; ZUNKER, P.; DIETRICH, D.; BERNIMOULIN, J.P. Periapical and periodontal healing after osseous grafting and guided tissue regeneration treatment of apicomarginal defects in periradicular surgery: Results after 12 months. Oral Surg. Oral Med. Oral Pathol. Oral Radiol. Endod., v. 95, n. 4, apr, p. 474-482, 2003.

38. DODGSON, K.S.; SPENCER, B. Methods of Biochemistry Analysis, Ed.: Interscience, v. 4, p. 221-255, 1957.

39. DRAPER, R. K.; FISKUM. G. M.; EDMOND J. Purification, molecular weight, amino acid subunit composition of arylsulfatase A from human liver. Arch. Biochem. Biophys., v. 177, p. 525-538, 1976. 
40. DREXLER, H.G.; GIGNAC, S.M. Characterization and expression of tartrate-resistant acid phosphatase (TRAP) in hematopoietic cells. Leukemia., v. 8, n. 3, mar, p. 359368, 1994.

41. DRURY, G.I. \& YUKNA, R.A. Histologic evaluation of combining tetracycline and allogeneic freeze-dried bone on bone regeneration in experimental defects in baboons. J. Periodontol. v. 62, n. 11, p. 652-658, 1991.

42. DZIALOZYNSKI, L. M.; GNIOT-SZULZYCKA, J. The clinical aspects of arylsulphatase activity, Clin. Chim. Acta., v. 15, p. 381-386, 1967.

43. EGGERT, F.M. \& GERMAIN, J.P. Stable acid phosphatase: I. Demonstration and distribution. Histochemistry., v. 66, n. 3, p. 307-317, 1980.

44. EICKHOLZ, P.; KIM, T.-S.; HOLLE, R. Guided tissue regeneration with nonresorbable and biodegradable barriers: 6-month results. J. Clin. Periodontol., v. 24, n. 2, p. 92-101, 1997.

45. ELEY, B.M.; COX, S.W. Proteolytic and hydrolytic enzymes link with periodontitis. Brist. Dent. J., v. 184, p. 323-327, 1998.

46. FAROOQUI, A.A.; MANDEL, P. The clinical aspects of arylsulphatases. Clin. Chim. Acta., v. 74, p. 93-100, 1977.

47. FILBURN, C.R. \& KARN, J. An isotopic assay of cyclic 3',5'-nucleotide phosphodiesterase with aluminum oxide columns. Anal Biochem., v. 52, n. 2, apr, p. 505-516, 1973. 
48. FRIESEN, L.R.; WILLIAMS, K.B.; KRAUSE, L.S.; KILLOY, W.J. Controlled local delivery of tetracycline with polymer strips in the treatment of periodontitis. $\boldsymbol{J}$. Periodontol., v. 73, p. 13-19, 2002.

49. FUGAZZOTTO, P.A. The use of demineralized laminar bone seets in guided bone regeneration procedures: report of three cases. Int. Maxillofac. Implants, v. 11, n. 2, p. 239-244, 1996.

50. FUKUSHIMA, O; BEKKER, P.J.; GAY, C.V. Ultrastructural localization of tartrateresistant acid phosphatase (purple acid phosphatase) activity in chicken cartilage and bone. Am J Anat., v. 191, n. 3, jul, p. 228-236, 1991.

51. GAlgut, P., PItrola, R., WAite, I., DOYle, C., SMith, R. Histologica evaluation of biodegradable and non-degradable membranes placed transcutaneously in rats. J. Clin. Periodontol. v. 18, n. 8, p. 581-586, 1991.

52. GRANJEIRO, J.M., FERREIRA, C.V., JUCÁ, M.B., TAGA, E.M., AOYAMA, H. Bovine kidney low molecular weight acid phosphatase: FMN-dependent kinetics. Biochem. Mol. Biol. Int., v. 41, n. 6, p. 1201-1208, 1997.

53. GRANJEIRO, J.M., TAGA, E.M., AND AOYAMA, H. Purification and Characterization of a Low-Molecular-Weight Bovine Kidney Acid Phosphatase. An. Acad. Bras. Ci., v. 69, n. 4, p. 451-460, 1997.

54. GREENWALD, R.A.; GOLUB, L.M.; RAMAMURTHY, N.S.; CHOWDHURY, M.; MOAK, S.A.; SORSA, T. In vitro sensitivity of three mammalian collagenases to tetracycline inhibition: Relationship to bone bone and cartilage degradation. Bone, v. 22, n. 1, p. 33-38, 1998. 
55. GRIFFITH, L.G. Polymeric biomaterials. Acta mater., v. 48, p. 263-277, 2000.

56. HALLEN, J. M.; KAIJA, H.; STEPAN, J. J.; VIHKO, P.; VÄÄNÄNEN, H. K. Studies on the protein tyrosine phosphatase activity of tartrate-resistant acid phosphatase. Arch. Biochem. Biophys., v.352, p.97-102, 1998.

57. HARRIS, R.J. A clinical evaluation of guided tissue regeneration with a bioabsorbable matrix membrane combined with an allograft bone graft. A series of case reports. $\boldsymbol{J}$. Periodontol.,v. 68, n. 6, p. 598-607, 1997.

58. HARRIS, R.J. A clinical evaluation an allograft combined with a bioabsorbable membrane versus an alloplast/allograft composite graft combined with a bioabsobable membrane. 100 consecutively treated cases. J. Periodontol., v. 69, n. 5, p. 536-546, 1998.

59. HARRIS, R.J. Treatment of furcation defects with an allograft-alloplast-tetracycline composite bone graft combined with GTR: Human histologic evaluation of a case Report. Int. J. Periodontics Restorative Dent., v. 22, n. 4, p. 381-387, 2002.

60. HERCUliAnI, P. P.; CESTARI, T. M.; TAGA, E. M.; TAGA, R. Tratamento de defeito ósseo perene em calvária de cobaia com membrana de cortical óssea bovina liofilizada associada ou não a enxerto ósseo bovino desmineralizado. Rev. Bras. Implant., v. 7, n. 2, p. 7-14, 2000.

61. HIMENO, M.; NAKAMURA, K.; YAMADA, Y.; TANAKA, H.; IMOTO, T. KATO, K.Mechanisms of a conversion from membrane associated lysosomal acid phosphatase to content forms. Biochem Biophys Res Commun., v. 180, n. 3, nov, p. 1483-1489, 1991. 
62. HONKE, K.; FUJII, T.; MAKITA, D. Arylsulfatase A protein in sera of cancer patiens. Cancer J., v. 8, p. 139-143, 1995.

63. HOUSER, B.E.; MELlONING, J.M.; BRUNSVOLD, M.A.; COCHRAN, D.L.; MEFFERT, R.M.; ALDER, M.E. Clinical evaluation of anorganic bovine bone xenograft with a bioabsorbable collagen barrier in the treatment of molar furcation defects. Int. J. Periodontics Restorative Dent., v. 21, n. 2, p. 161-169, 2001.

64. HURZELER, M.B., KOHAL, R.J., NAGHSHBANDI, J., MOTA, L.F., CONRADT, J., HUTAMACHER, D., CAFFESSE, R.G. Evaluation of a new bioabisorbable barrier to facilitate guided bone regeneration around exposed implant threads. An experimental study in the monkey. Int. J. Oral Maxillofac. Surg. v. 27, n. 4, p. 315-320, 1998.

65. HUTMACHER, D.W. Scaffolds in tissue engineering bone and cartilage. Biomaterials., v. 21 , n. 24 , p. $2529-2543,2000$.

66. HYDER, P.R.; DOWELL, P.; SINGH, G.; DOLBY, A.E. Freeze-dried, cross-linked bovine type I collagen: analysis of properties. J Periodontol., v. 63, n. 3, mar, p. 182-186, 1992.

67. JANCKILA, A.J.; YAZIJI, H.; LEAR, S.C.; MARTIN, A.W.; YAM, L.T. Localization of tartrate-resistant acid phosphatase in human placenta. Histochem J., v. 28, n. 3, mar, p. 195-200, 1996.

68. JANSEN, J.A.; DE RUIJTER, J.E.; JASSEN, P.T.M.; PAQUAY, Y.G.C.J. Histological evaluation of a biodegradable polyactive/hydroxyapatite membrane. Biomaterials. v. 16, p. 819-827, 1995. 
69. KAHNBERG, K.E. Restoration of mandibular jaw defects in the rabbit by subperiosteally implanted Teflon mantle leaf. Int J Oral Surg., v. 8, n. 6, dec, p. 449-456, 1979.

70. KASSOLIS, J.D. \& BOWERS, G.M. Supracrestal bone regeneration: a pilot study. Int. J. Periodontics Restorative Dent., v. 19, n. 4, p. 314, 1999.

71. KELLY, J.D., SCHNEIDER, G.B. Morphological and Histochemical Comparison of Cells Elicited by Ectopic Bone Implants and Tibial Osteoclasts. Am. J. Anat. v. 192 (3), p. 45-54, 1991.

72. KHAYAT, A.; VESAL, N.; RASTI, M. Analysis of arylsulfatases A and B, acid phosphatase, lactate dehydrogenase, and aspartate transaminase in chronic periapical lesions of endodontic origin. J. Endod., v. 27, n. 4, p. 285-287, 2001.

73. KIM, T.-S.; HOLLE, R.; HAUSTMANN, E.; EICKHOLZ, P. Long-term results of guided tissue regeneration therapy with non-resorbable and bioabsorbable barriers. II. A case series of infrabony defects. J. Periodontol., v. 73, n. 4, p. 450-459, 2002.

74. KRAENZLIN, M.E.; LAU, K.H.; LIANG,L.; FREEMAN, T.K.; SINGER, F.R.; STEPAN, J.; BAYLINK, D.J. Development of an immunoassay for human serum osteoclastic tartrate-resistant acid phosphatase. J Clin Endocrinol Metab., v. 71, n. 2, aug, p. 442-451, 1990.

75. LAIDLER, P.; KOWALSKI, D.; SILBERRING, J. Arylsulfatase A in serum from patients with cancer of various organs. Clin. Chim. Acta., v. 204, p. 69-78, 1991.

76. LAMSTER, I.B.; OSHARAIN, R. I.; HARPER, D.S.; CELENTI, R.S.; HOVILARAS, C.A.; GORDON, J.M. Enzyme activity in crevicular fluid for detection and 
prediction of clinical attachment loss in patients with chronical adult periodontitis. J. Periodontol., v. 59, p. 516-523, 1988.

77. LANGER R, VACANTI JP. Tissue engineering. Science, v. 260, n. 5110, p. 920-926, 1993.

78. LEE, C.H., SINGLA, A., LEE, Y. Biomedical applications of collagen. Int. J. Pharm., v. 221 , n. 1 , p. $1-22,2001$.

79. LEONARDIS, D.; GARG, A.K.; PEDRAZZOLI, V.; PECORA, G.E. Clinical evaluation of the treatment of class II furcation involvements with bioabsorbable barriers alone or associated with demineralized freeze-dried bone allografts. $\boldsymbol{J}$ Periodontol., v. 70, n. 1, jan, p. 8-12, 1999.

80. LI, R.H. \& WOZNEY, J.M. Delivering on the promise of bone morphogenetic proteins. Trends in Biotechnology, v. 19, n. 7, p. 255-265, 2001.

81. LIN, C.W. \& FISHMAN, W.H. L-Homoarginine. An organ-specific, uncompetitive inhibitor of human liver and bone alkaline phosphohydrolases. J Biol Chem., v. 247, n. 10, may, p. 3082-3087, 1972.

82. LindE A.; ALbERIUS, P.; DAhLIN, C.; BJURSTAM, K., SUNDIN, Y. Osteopromotion: A soft-tissue exclusion principle using a membrane for bone bealing and bone neogenesis. J Periodontol. v. 64, p. 1116-1128, 1993.

83. LING, L.-J.; HUNG, S.-L.; LEE, C.-F.; CHEN, Y.-T.; WU, K.-M. The influence of membrane exposure on the outcomes of guided tissue regeneration: clinical and microbiological aspects. J. Periodont. Res., v. 38, p. 57-63, 2003. 
84. MAJZOUB, Z.; CORDIOLI, G.; ARAMOUNI, P.K.; VIGOLO, P.; PIATTELli, A. Guided bone regeneration using demineralized laminar bone sheets versus GTAM membranes in the treatment of implant-associated defects. A clinical and histological study. Clin. Oral Implants Res., v. 10, n. 5, p. 406-414, 1999.

85. MATSUMOTO, A.; YAMAJI, K.; KAWANAMI, M.; KATO, H. Effect of aging on bone formation induced by recombinant human bone morphogenetic protein-2 combined with fibrous collagen membranes at subperiosteal sites. J. Periodont. Res., v. 36, p. 175-182, 2001.

86. MISCH, C.E.; DIETSH, F. Bone-grafting materials in implant dentistry. Implant Dentistry, v. 2, n. 3, p. 158-67, 1993.

87. NAKAMURA, M.; GASA, S.; MAKITA, A. Arylsulfatase A from normal human lung tumors ahowed different patterns of microheterogeneity. J. Biochem., v. 96, p. 207213, 1984.

88. NEEDLEMAN, I.; TUCKER, R.; GIEDRYS-LEEPER, E.; WORTHINGTON, H. A systematic review of guided tissue regeneration for periodontal infrabony defects. J. Periodont. Res., v. 37, p. 380-388, 2002.

89. NICHOLLS, R. G.; ROY, A. B. Arilsulfatases. Enzymes, v. 5, p. 21-41, 1971.

90. NYMAN, S., LINDHE, J., KARRING, T., RYLANDER, H. New attachment following surgical treatment of human periodontal disease. J. Clin. Periodontol., v. 9, n. 4, p. 290-296, 1982.

91. ODDIE, G.W.; SCHENK, G.; ANGEL, N.Z.; WALSH, N.; GUDDAT, L.W.; JERSEY, J.;CASSADY, A.I.; HAMILTON, S.E.; HUME, D.A. Structure, Function, and 
Regulation of Tartrate-Resistant Acid Phosphatase. Bone v. 27, n. 5, p. 575-584, 2000.

92. OH, T.J.; MERAW, S.J.; LEE, E.J.; GIANNOBILE, W.V.; WANG, H.L. Comparative analysis of collagen membranes for the treatment of implant dehiscence defects. Clin. Oral Impl. Res., v. 14, p. 80-90, 2003.

93. OHNISHI, H., FUJII, N., FUTAMI, T., TAGUCHI, N., KUSAKARI, H., MAEDA, T. A histochemical investigation of the bone formation process by guided bone regeneration in rats jaws. Effect of PTFE membrane application periods on newly formed bone. J. Periodontol., v. 71, n. 3, p. 341-352, 2000.

94. OLIVEIRA, R.C., et al. Efeito da Temperatura de Desproteinização no Preparo de Osso Cortical Bovino Microgranular. Avaliação Microscópica e Bioquímica da Resposta Celular em Subcutâneo de Ratos. Rev. FOB, v. 7, n.3/4, p. 85-93, 1999.

95. OMER, B.; ONER, P.; MANYASLI, M.; AKTAN, M. Leukocyte arylsulphatase A activity in leukemia. Cancer Biochem. Biophys., v. 14, p. 53-56, 1994.

96. PAGE, R.C. Host response tests for diagnosing periodontal discases. J. Periodontal., v. 63, p. 356-366, 1992.

97. PANARA, F.; ANGIOLILlO, A.; PASCOLINI, R. Acid phosphatases from liver of Rana esculenta. Subcellular localization and partial characterization of multiple forms. Comp Biochem Physiol B., v. 93, n. 4, p. 877-882, 1989.

98. PAOLANTONIO, M. Combined periodontal regenerative technique in human intrabony defects by collagen membranes and anorganic bovine bone. A controlled clinical study. J. Periodontol., v. 73, n. 2, p. 158-166, 2002. 
99. PARODI, R.; CARUSI, G.; SANTARELLI, G.; NANNI, F.; PINGITORE, R.; BRUNEL, G. Guided tissue regeneration employing a collagen membrane in a human periodontal bone defect: A histologic evaluation. Int. J. Periodont. Rest. Dent., v. 17, n. 3, p. 283-291, 1997.

100. PARODI, R.; CARUSI, G.; SANTARELLI, G.; NANNI, F. Implant placement in large edentulous ridges expanded by GBR using a bioresorbable collagen membrane. Int. J. Periodont. Rest. Dent., v. 18, n. 3, p. 267-275, 1998.

101. PAUl, B.F., MELlONING, J.T., TOWLE III, H.J., GRAY, J.L. Use of collagen a barrier to enhance healing in human periodontal furcation defcts. J. Periodont. Rest. Dent. v. 12, n. 2, p. 123-131, 1992.

102. PECORA, G.; KIM, S.; CELLETTI, R.; DAVARPANAH, M. The guided tissue regeneration principle in endodontic surgery: one-year postoperative results of large periapical lesions. Int. Endod. J., v. 28, n. 1, jan, p. 41-46, 1995.

103. PIETTE, E.; ALBERIUS, P.; SAMMAN, N.; LINDE, A. Experience with e-PTFE membrane application to bone grafting of cleft maxilla. Int $\boldsymbol{J}$ Oral Maxillofac Surg. v. 24, n. 5, oct, p. 327-332, 1995.

104. PITARU, S., TAL, H., SOLDINGER, M., AZAR-AVIDAN, O., NOFF, M. Collagen membranes prevent the apical migration of epithelium during periodontal wound healing. J. Periodont. Res., v. 22, n. 4, p. 331-333, 1987.

105. PITARU, S., TAL, H., SOLDINGER, M. GROSSKOPF, A., NOFF, M. Partial regeneration of periodontal tissues using collagen barriers. Initial observations in the canine. J. Periodontol., v. 59, n. 6, p. 380-386, 1988. 
106. PITARU, S., TAL, H., SOLDINGER, M., NOFF, M. Collagen membranes prevent apical migration of epithelium and support new connective tissue attachment during periodontal wound healing in dogs. J. Periodont. Res., v. 24, n. 4, p. 247-253, 1989.

107. PITARU, S., McCULlOCH, C.A.; NARAYANAN, S.A. Cellular origins and differentiation control mechanisms during periodontal development and wound healing. J Periodontal Res.,v. 29, n. 2, mar, p. 81-94, 1994.

108. RACHLIN, G., KOUBI, G., DEJOU, J., FRANQUIN, J.C. The use of a resorbable membrane in mucogingival surgery. Case series. J. Periodontol., v. 67, n. 6, p. 621626, 1996.

109. REDDI, A.H., AND HUGGINS, C. Biochemical sequences in the Transformation of Normal Fibroblasts in Adolescent Rats. Proc. Natl. Acad. Sci. U.S.A., v. 69, p. 1601-1605, 1972.

110. RICO, H. \& VILA, V.L. Serum tartrate-resistant acid phosphatase (TRAP) as a biochemical marker of bone remodeling. Calcif Tissue Int., v. 52, n. 2, feb, p. 149$150,1993$.

111. ROCHA, L.B., GOISSIS, G., ROSSI, M.A. Biocompatibility of anionic collagen matrix as scaffold for bone healing. Biomaterials, v. 23, n. 2, p. 449-456, 2002.

112. ROSENBERG, E., ROSE, L. Biologic and clinical considerations for autografts and allografts in periodontal regeneration therapy. Dental Clinics of North America., v. 42, n. 3, p. 467-490, 1998. 
113. ROY, A. B. The type II arylsulphatase of the red kagaroo. Biochim. Biophys. Acta., v. 227, p. 129-138, 1971.

114. ROY, A. B.; JERFY, A. The sulphatase of ox liver XIV. The subunit structure of sulphatase A. Biochim. Biophys. Acta., v. 207, p. 156-163, 1970.

115. SALONEN, J.I. \& PERSSON, G.R. Migration of epithelial cells on materials used in guided tissue regeneration. J. Periodont. Res., v. 25, n. 4, p. 215-221, 1990.

116. SANCHEZ, M.P.R.; MARZOLA, C.; TAGA, R. Avaliação microscópica em ratos (Wistar albinus) de implantes de matriz de osso bovino liofilizado "Biograft" + proteína morfogenética + membrana reabsorvível de osso bovino liofilizado "Dentoflex". Rev.Brasileira Cirurgia e Implantodontia., v. 7, n. 27, jul-set, p. 30$39,2000$.

117. SASAKI, T.; RAMAMURTHY, N.S.; GOLUB, L.M. Tetracycline administration increases collagen synthesis in osteoblasts of strepozotocin-induced diabetic rats: A quatitative autoradiographic study. Calcif. Tissue Int., v. 50, n. 5, p. 411-419, 1992.

118. SAUNDERS, P.T.; RENEGAR, R.H.; RAUB, T.J; BAUMBACH, G.A.; ATKINSON, P.H.; BAZER, F.W.; ROBERTS, R.M. The carbohydrate structure of porcine uteroferrin and the role of the high mannose chains in promoting uptake by the reticuloendothelial cells of the fetal liver. J Biol Chem., v. 260, n. 6, mar, p. 3658$3665,1985$.

119. SBORDONE, L.; BARONE, A.; DI GENIO, A.; RAMAGLIA, L. S Bacterial colonisation during GTR treatment. A longitudinal analysis. Minerva Stomatol., v. 48, n. 11, nov, p. 501-508, 1999. 
120. SCHLEGEL, A.K., MOHLER, H., BUSCH, F., MEHL, A. Preclinical and clinical studies of a collagen membrane (Bio-Gide ${ }^{\circledR}$ ). Biomaterials, v. 18, n. 7, p. 535-538, 1997.

121. SCOTT, T.A.; TOWLE, H.J.; ASSAD, D.A.; NICOLL, B.K. Comparison of bioabsorbable laminar bone membrane and non-resorbable ePTFE membrane in mandibular furcations. J. Periodontol., v. 68, n. 7, p. 679-686.

122. SCULEAN, A.; DONOS, N.; CHIANTELlA, G.C.; WINDISCH, P.; REICH, E.; BRECX, M. GTR with bioresorbable membranes in the treatment of intrabony defects: a clinical and histologic study. Int J Periodontics Restorative Dent., v. 19, n. 5, oct, p. 501-509, 1999.

123. SEAL, B.L.; OTERO, T.C.; PANITCH, A. Polymeric biomaterials for tissue and organ regeneration. Materials Science and Engineering R, v. 34, p. 147-230, 2001.

124. SHIEH, A.T., WANG, H.L., O`NEAL, R., GLICKMAN, G.N. Development and clinical evaluation of a root coverage procedure using a collagen barrier membrane. J. Periodontol., v. 68, n. 8, p. 770-778, 1997.

125. SICCA, C.M. et al., Avaliação microscópica e bioquímica da resposta celular a enxertos de osso cortical bovino em subcutâneo de ratos. Efeito do tamanho da partícula. Rev. FOB, v. 8, n. 1/2, p. 1-10, 2000.

126. SOGAL, A., TOFE, A.J. Risk assessment of bovine spongiform encephalopathy transmission through bone graft material derived from bovine bone used for dental applications. J. Periodontol., v. 70, n. 9, p. 1053-1063, 1999. 
127. STEFANI, M.; CASElli, A.; BUCCIANTINI, M.; PAZZAGLI, L.; DOLFI, F., CAMICI, G.; MANAO, G.; RAMPONI, G. Dephosphorylation of tyrosine phosphorylated synthetic peptides by rat liver phosphotyrosine protein phosphatase isoenzymes. FEBS Lett., v. 326, n. 1-3, jul, p. 131-134, 1993.

128. STERRET, J.D.; SIMMONS, J.; WHITFORD, G.; RUSSELL. Tetracycline demineralization of dentin: the effects of concentration and application time. $\boldsymbol{J}$. Clin. Periodontol., v. 24, n. 7, p. 457-463, 1997.

129. TAGA, E.M.; WAHEED, A.; VAN ETTEN, R.L. Structural and chemical characterization of a homogeneous peptide $\mathrm{N}$-glycosidase from almond. Biochemistry., v. 23, n. 5, p. 815-822, feb, 1984.

130. TAGA, R., HASSUNUMA, C.Y., CESTARI, T.M., FERREIRA, P.M. Destino de membrana de cortical óssea bovina colocada em posição subperiostica na calvária de cobaia. Rev. Bras. Implant., p. 24-29, 1997.

131. TAGA, R., CESTARI, T.M., TAGA, E.M., ASSIS, G.F., MARINE, M.G. Avaliação histológica, radiográfica e morfometrica da reparação de defeito ósseo perene em crânio de cobaia tratado com mistura de osseobond e membrana de cortical óssea bovina colocada em posição subperiostica na calvária de cobaia. Rev. Bras. Implant., p. 24-29, 1997.

132. URIST, M.R. Bone: formation by autoinduction. Science, v. 150, n. 698, p. 893-99, 1965.

133. URIST, M.R.; STRATES, E.S. Bone formation in implants of partially and wholly demineralized bone matrix. Clin. Orthop. Rel. Res, v. 71, p. 271-78, 1970. 
134. VINCENT, J.B. \& AVERILL, B.A. An enzyme with a double identity: purple acid phosphatase and tartrate-resistant acid phosphatase. FASEB J., v. 4, n. 12, sep, p. 3009-3014, 1990.

135. VITAIOLI, L.; BALDONI, E.; RICCI, R.; INDRACCOLO, S. R. Expression of acidic glycosphingolipids and arylsulphatase A activity in human pathological endometrium. Eur. J. Obstet. Gynecol. Reprod. Biol., v. 54, p. 31-35, 1994.

136. WAHEED, A.; VAN ETTEN, R. L. Covalent modification as the cause of the anomalous kinetics of aryl sulfatase A. Arch. Biochem. Biophys., v. 195, p. 248$251,1979$.

137. WAHEED, A.; VAN ETTEN, R. L. Purification of mammalian arylsulfatase A enzymes by subunit affinity chromatography. Int. J. Pept. Protein. Res., v. 26, p. $362-372,1985$.

138. WAKABAYASHI, R.C.; WONG, F.; RICHARDS, D.W.; JOHNSON, P.W. Protease repertoires of cells adherent to membranes recovered after guided tissue regeneration. J Periodontal Res., v. 31, n. 3, apr, p. 171-180, 1996.

139. WANG, H.L., MACNEIL, R.L. Guided tissue regeneration. Absorbable barriers. Dental Clinics of North America., v. 42, n. 3, p. 505-522, 1998.

140. WANG, H.L., KIMBLE, K., EBER, R. Use of bone grafts for the enhancement of a GTR-based root coverage procedure: a pilot case study. Int. J. Periodontics Restorative Dent., v. 22, n. 2, p. 118-127, 2002. 
141. WANG, H.L., MIYAUCHI, M., TAKATA, T. Initial attachment of osteoblasts to various guided bone regeneration membranes: an in vitro study. J. Periodont. Res. v. 37, n. 5, p. 340-344, 2002.

142. WARRER, K., KARRING, T., NYMAN, S., GOGOLEWSKI, S. Guided tissue regeneration using biodegradable membranes of polylactic acid or polyurethane. $\boldsymbol{J}$. Clin. Periodontol., v. 19, n. 9, p. 633-640, 1992.

143. WINDISCH, P.; SCULEAN, A.; GERA, I. GTR with three different types of membranes in the treatment of intrabony periodontal defects: three-year results in sixty consecutive cases. J Long Term Eff Med Implants, v. 9, n. 3, p.235-246, 1999.

144. YAMADA, S.; SHIMA, N.; KITAMURA, H.; SUGITO, H. Effect of porous xenographic bone graft with collagen barrier membrane on periodontal regeneration. Int. J. Periodontics Restorative Dent., v. 22, n. 4, p. 389-397, 2002.

145. YAMAOKA, S.B.; MELLONIG, J.T.; MEFFERT, R.M.; ARNOLD, R.M.; NUMMIKOSKI, P.V.; MEALEY, B.L. Clinical evaluation of demineralizedunicortical-ilium-strips for guided tissue regeneration. J. Periodontol., v. 67, n. 8, p. 803-815, 1996.

146. YUKNA, C.N., YUKNA, R. A. Multi-Center evaluation of bioabsorbable collagen membrane for guided tissue regeneration in huuman class II furcations. $\boldsymbol{J}$. Periodontol., v. 67, n. 7, p. 650-657, 1996.

147. ZHAO, S.; PINHOLT, E.M.; MADSEN, J.E.; DONATH, K. Histological evaluation of diferent biodegradable and non-biodegradable membranes 
implanted subcutaneously in rats. Journal of Cranio-Maxillofacial Surgery. v. 2000 , n. 28 , p. $116-122,2000$

148. ZITZMANN, N.U., NAEF, R., AND SCHARER, P. Resorbable versus nonresorbable membranes in combination with Bio-Oss for guided bone regeneration. Int. J. Oral Maxillofac. Implants, v. 12, n. 6, p. 844-852, 1997. 
10. ANEXO 


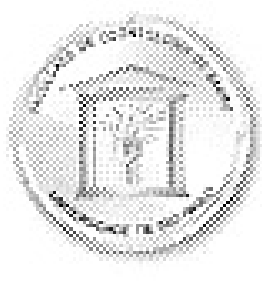

\author{
Universidade de São Paulo \\ Faculdade de Odontologia de Bauru \\ AL. Dr. Octävio Pinheiro Brisolla, 9-75 - Bauru-SP-CEP 17012-901 - C.P. 73 \\ PABX (0XX14)235-8000-FAX (0XX14)223-4679 \\ Departamento de Ciências Biológicas \\ e-mail: dep-cibia fob usp.br - Fonc: (0XX14)235-8282
}

Abril, 01, 2003

\title{
DECLARAÇĀO
}

Declaro que a pesquisa intitulada "Avaliação microscópica e bioquímica comparativa de membrana de osso cortical bovino desmineralizado, tratada ou não com tetraciclina, colocada em subcutảneo de ratos" dos autores Oliveira RC; Taga R; Granjeiro JM foi desenvolvida seguindo os principios propostos em 1959 por Russel e Burch e ratificados em Assembléia da UNESCO, em Bruxelas, em 21/01/78, que culminou com a Declaração dos Direitos dos Animais, especificamente em seus artigos $8^{\circ}$, letra a) e b) e $14^{\circ}$ e do sugerido no texto: Principios Éticos na Experimentação Animal - Colégio Brasileiro de Experimentação Animal COBEA.

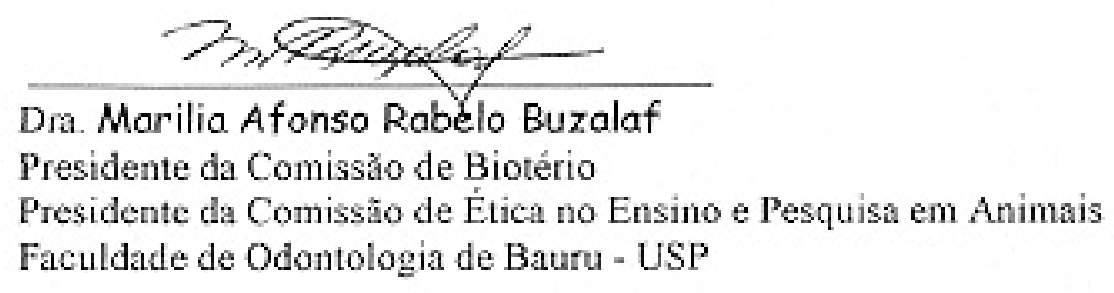




\begin{abstract}
Guided tissue regeneration, the procedure in witch a barrier is used to keep the epithelium away from root surfaces, has been shown to partially regenerate lost periodontal tissue with new bone, periodontal ligament, and cementum. Several materials, both nonabsorbable and biosorbable barriers have been develop in an attempt to achieve complete periodontal regeneration. More recently, the membrane barriers have also been applied for regenerating bone surrounding peri-implant defects, in the so-called guided bone regeneration. Despite the actual knowledge on the collagen-derived membranes, little information about cellular response to bovine demineralized bone membranes is available. The aim of this study was to evaluate the cellular response and to verify the enzymatic active to organic membrane derived from bovine bone implanted in rat subcutaneous. 120 rats were killed 1, 3, 7, 15, 30 and 60 days post membrane implantation. Microscopic analysis focused the inflammatory response and the membrane integrity during the experimental time. At 7 and 15 days after implantation was observed a moderate inflammatory response, which decreased to the end of experiment. Membrane bioabsorption started 15 days post implantation and just few small pieces last after 60 days. Sparse multinucleated macrophages were observed during the periods, almost disappearing after 60 days. Lisossomal enzyme markers (lisossomal acid phosphatase, arylsulfatase and $\beta$-hexosaminidase) and alkaline phosphatase were more active during the first 3 days post-implantation and are not involved in the membrane aborption. The membrane derived from demineralized bovine bone did not induce an immunologic or allergic response and was almost completely absorbed after 60 days.
\end{abstract}

